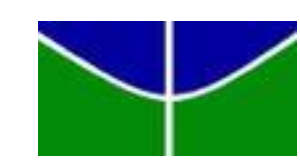

Universidade de Brasília - UnB

Faculdade de Economia, Administração e Contabilidade - FACE

Programa de Pós-Graduação em Economia

Mestrado Profissional em Gestão Econômica de Finanças Públicas

\title{
O PROGRAMA NACIONAL DE ASSISTÊNCIA ESTUDANTIL:
}

O caso da Universidade de Brasília

\author{
Mendel de Almeida Queiroz
}

Brasília-DF 
MENDEL DE ALMEIDA QUEIROZ

\section{O PROGRAMA NACIONAL DE ASSISTÊNCIA ESTUDANTIL:}

\section{O caso da Universidade de Brasília}

Dissertação de Mestrado apresentada ao Programa de Pós-Graduação em Economia da Faculdade de Economia, Administração e Contabilidade da Universidade de Brasília, como parte dos requisitos para obtenção do título de Mestre em Economia.

Orientadora: Prof $^{\mathrm{a}}$. Dra ${ }^{\mathrm{a}}$. Geovana Lorena Bertussi

Área de concentração: Finanças Públicas

Brasília-DF 
Universidade de Brasília - UnB

Faculdade de Economia, Administração e Contabilidade - FACE

Programa de Pós-Graduação em Economia

Mestrado Profissional em Gestão Econômica de Finanças Públicas

MENDEL DE ALMEIDA QUEIROZ

O PROGRAMA NACIONAL DE ASSISTÊNCIA ESTUDANTIL:

O caso da Universidade de Brasília

Dissertação de Mestrado apresentada ao Programa de Pós-Graduação em Economia da Faculdade de Economia, Administração e Contabilidade da Universidade de Brasília, como parte dos requisitos para obtenção do título de Mestre em Economia.

Orientadora: Prof ${ }^{a}$. Dr ${ }^{\mathrm{a}}$. Geovana Lorena Bertussi

Banca Examinadora:

Prof $^{a}$. Dr ${ }^{\mathrm{a}}$. Geovana Lorena Bertussi - Orientadora

Departamento de Economia - FACE/UnB

Profa. Dra. Andrea Felippe Cabello - Membro Interno

Departamento de Economia - FACE/UnB

Profa. Dra. Danielle Sandi Pinheiro - Membro Externo

Departamento de Administração - FACE/UnB

Aprovado em 1 
Aos meus pais, Dalvo e Josefina, pela doação de vida, dedicação e amor incondicional.

À minha esposa, Emannuela, pelo carinho e apoio recebido durante as horas difíceis deste curso. As minhas conquistas são suas. 


\section{AGRADECIMENTOS}

Primeiramente e, acima de tudo, agradeço a Deus pela oportunidade e força para conclusão deste curso. Para Ele, nada é impossível!

À professora Geovana Lorena Bertussi, pela orientação, ensinamento e incentivo em prol da conclusão do presente estudo.

Às professoras Andrea Felippe Cabello e Danielle Sandi Pinheiro, por comporem a banca examinadora e aceitarem o convite sem objeções.

Ao Departamento de Economia (ECO) da Universidade de Brasília (UnB), em especial, aos coordenadores e professores do curso que acreditaram no mestrado profissional para os servidores da Universidade.

À Decana de Assuntos Comunitários, professora Denise Bomtempo Birche de Carvalho, pela permissão de um horário especial para os estudos em meio às minhas atividades profissionais.

Aos colegas de trabalho do Decanato de Assuntos Comunitários (DAC).

Às equipes de trabalho da Diretoria de Desenvolvimento Social e da Secretaria de Administração Acadêmica da UnB, pelo amparo, dados e informações disponibilizados da assistência e permanência dos estudantes na Universidade.

À minha família e aos amigos que, de forma direta ou indireta, contribuíram nesta jornada, em especial, às minhas irmãs Janaina e Tainah, que mesmo de longe, torcem por mim. A vocês, todo o meu amor e gratidão. 
"O grande segredo da educação consiste em orientar a vaidade para os objetivos certos."

Adam Smith 


\section{RESUMO}

O presente estudo teve por objetivo demonstrar como a Universidade de Brasília se comportou após a implementação do Programa Nacional de Assistência Estudantil, e como este pode ser orientado para contribuir com o desenvolvimento econômico nacional. Para tanto, verificou-se o número de estudantes beneficiados pela Assistência Estudantil, os programas ofertados e a forma de ingresso destes na Universidade. A Teoria do Capital Humano reforça a ideia que a educação é o principal instrumento de mobilidade social, e seus benefícios ultrapassam o ganho salarial, apontando o Ensino Superior como aquele que apresenta o maior crescimento na Taxa Interna de Retorno da Educação. E ainda, analisaramse os índices de trancamentos de matrículas e desligamentos ocorridos na referida instituição no período pré e pós-implantação do Programa supramencionado.

Palavras-chave: Programa Nacional de Assistência Estudantil. Ensino Superior. Capital humano. Taxa Interna de Retorno da Educação. 


\begin{abstract}
This study intended to demonstrate how the University of Brasilia behaved after the implementation of the National Student Assistance Program and how this can be oriented to contribute to national economic development. Therefore, it was found the number of students benefited from the Student Assistance, the programs who were offered to them and the way they got into University. The Theory of Human Capital reinforces the idea that education is the main instrument of social mobility and its benefits outweigh the wage gain, pointing Higher Education as one that has the highest Internal Rate of Return of Education. Besides, it was analyzed the interruption of enrollment and University shut downs occurred in that institution in the pre- and post-implementation of the program.
\end{abstract}

Keywords: National Student Assistance Program. Higher Education. Human capital. Internal Rate of Return of Education. 


\section{LISTA DE ABREVIATURAS E SIGLAS}

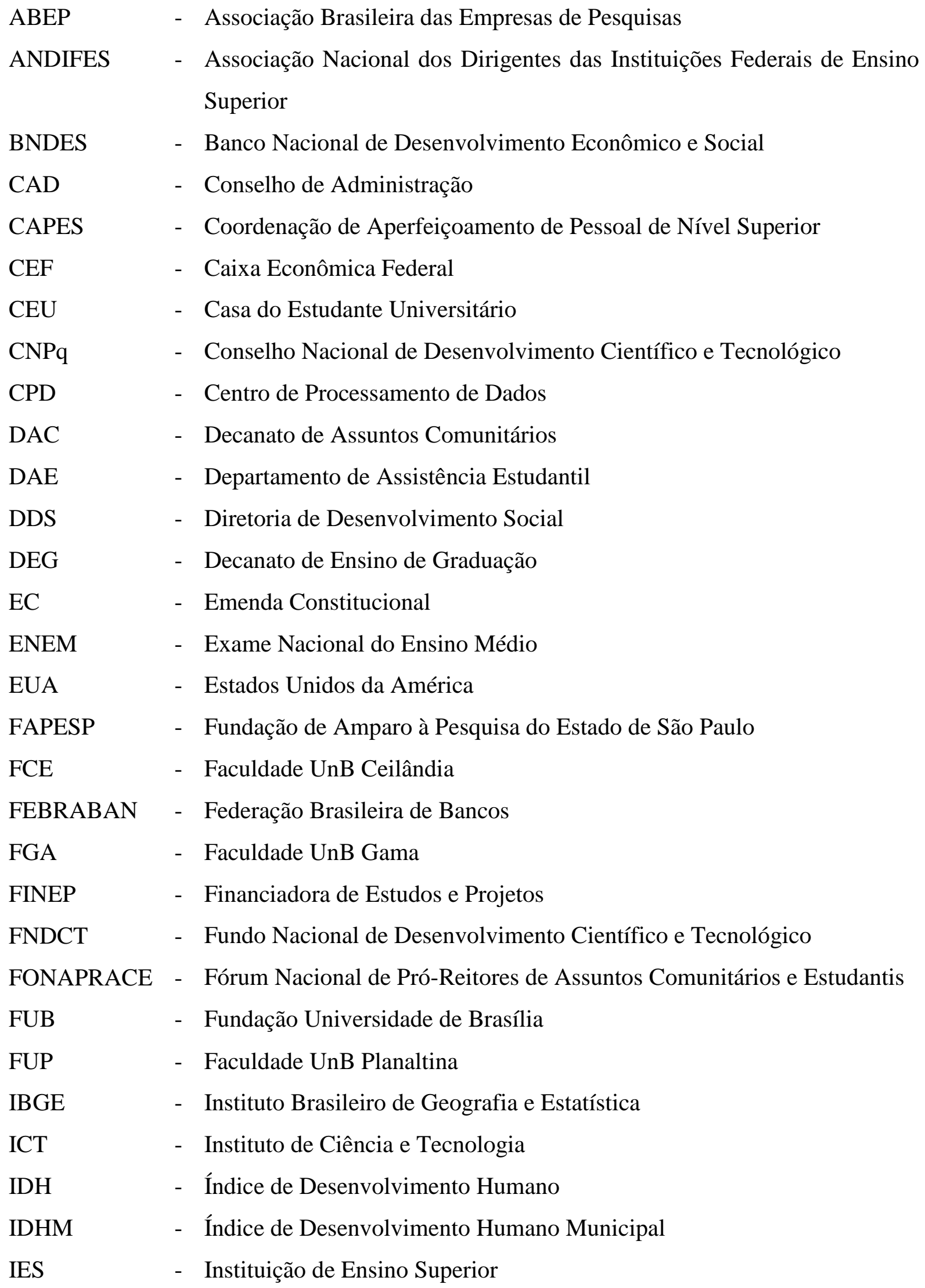




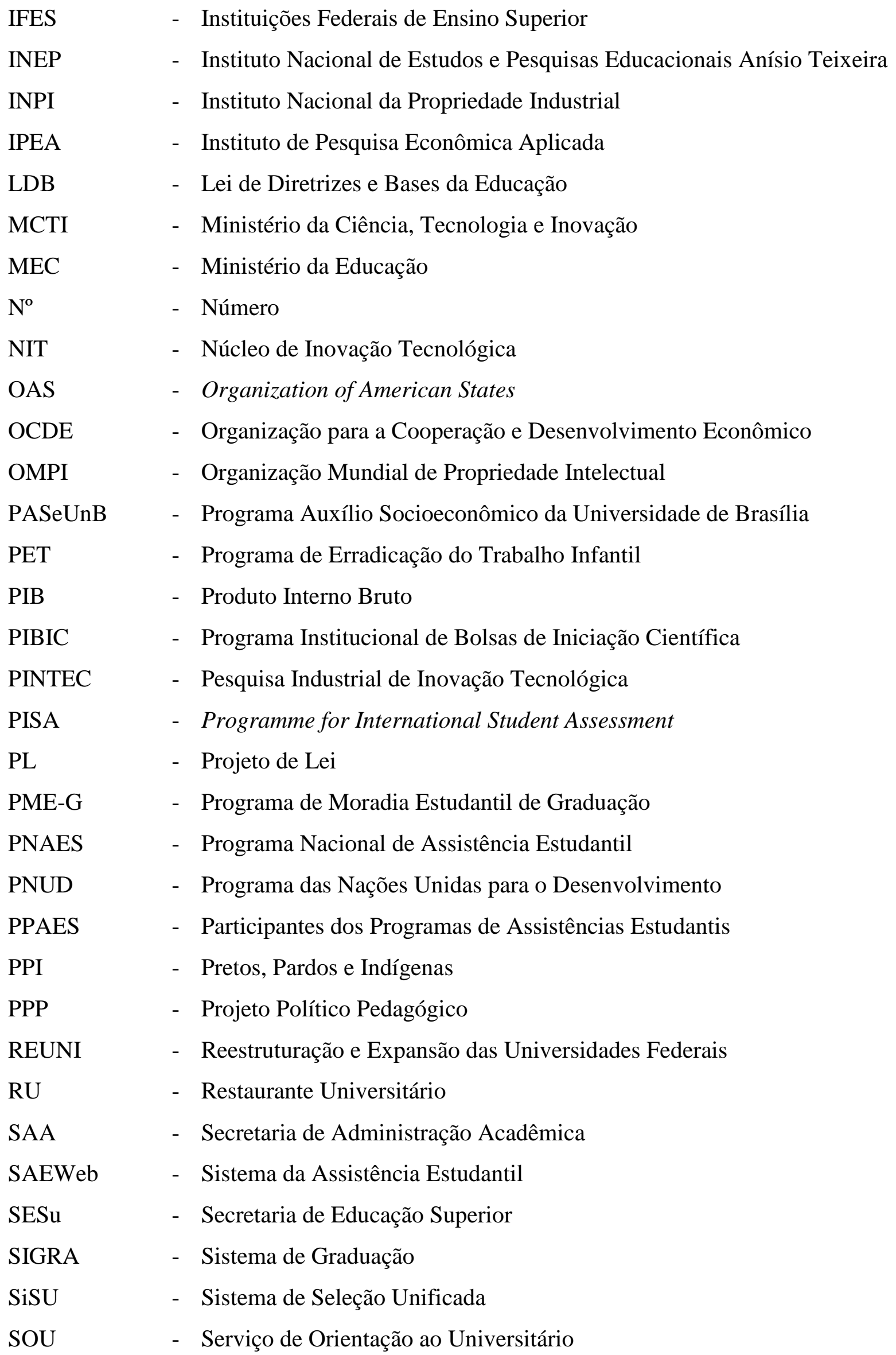


TIR

UF

UFMG

$\mathrm{UnB}$

UNE

UNICAMP

USP
- Taxa Interna de Retorno

- Unidade da Federação

- Universidade Federal de Minas Gerais

- Universidade de Brasília

- União Nacional dos Estudantes

- Universidade Estadual de Campinas

- Universidade de São Paulo 


\section{LISTA DE GRÁFICOS}

Gráfico 1 - Investimento na educação em relação ao Produto Interno Bruto brasileiro e internacional............................................................................................. 32

Gráfico 2 - Recursos do Programa Nacional de Assistência Estudantil para as Instituições Federais de Ensino Superior ................................................. 51

Gráfico 3 - Formados, trancamentos e desligamentos................................................... 75 


\section{LISTA DE QUADROS}

Quadro 1 - Tipos de conhecimento.................................................................. 21

Quadro 2 - Áreas estratégicas para o desenvolvimento econômico................................ 37

Quadro 3 - Quadro síntese metodológico................................................................ 60 


\section{LISTA DE TABELAS}

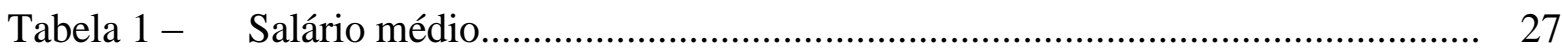

Tabela 2 - Comparativo da TIR sobre Educação........................................................ 27

Tabela 3 - Número de instituições de Ensino Superior.................................................. 29

Tabela 4 - $\quad$ Número de matrículas de graduação em 2011.......................................... 30

Tabela 5 - $\quad$ Investimento per capita por nível de ensino (US\$ - 1000)........................ 33

Tabela 6 - Matrículas no Ensino Superior por área................................................. 38

Tabela 7 - $\quad$ Percentual da população com nível superior............................................... 39

Tabela 8 - Percentual de estudantes nas Instituições Federais de Ensino Superior por 48 classe econômica

Tabela 9 - $\quad$ Renda média familiar por classe econômica............................................ 49

Tabela 10 - Trancamento de matrículas.................................................................... 50

Tabela 11 - Distribuição orçamentária do Programa Nacional de Assistência 53 Estudantil por região.

Tabela 12 - Benefícios distribuídos no Programa Nacional de Assistência Estudantil... 55

Tabela 13 - Número de estudantes regularmente matriculados na Universidade de 57 Brasília.

Tabela 14 - Número de beneficiados da Assistência Estudantil da Universidade de 69 Brasília.

Tabela 15- Recursos do Programa Nacional de Assistência Estudantil para a 69 Universidade de Brasília.

Tabela 16- Número de beneficiados e valores pagos - Programa de Auxílio 70 Socioeconômico da Universidade de Brasília.

Tabela 17 - Programa de Alimentação.................................................................... 71

Tabela 18 - Programa Auxílio Emergencial................................................................ 71

Tabela $19-\quad$ Média de trancamentos de matrículas e desligamentos................................ 77 


\section{SUMÁRIO}

1 INTRODUÇÃO ........................................................................................................................... 16

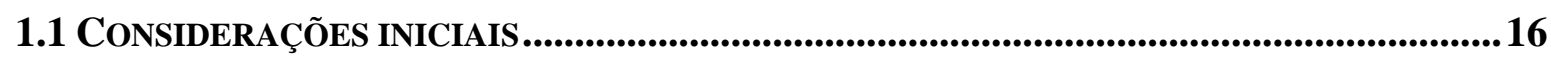

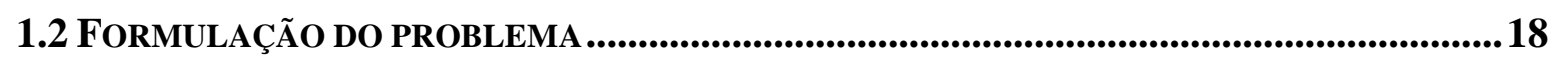

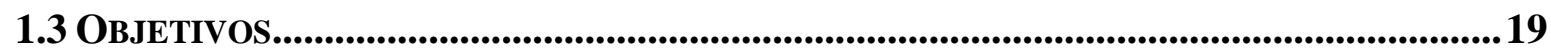

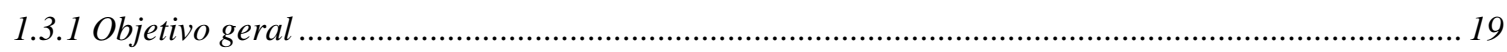

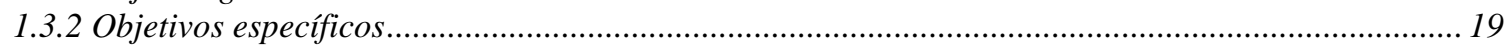

1.4 JUSTIFICATIVA .......................................................................................................................... 20

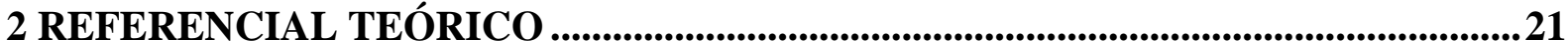

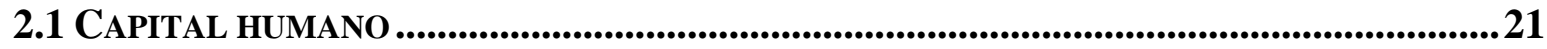

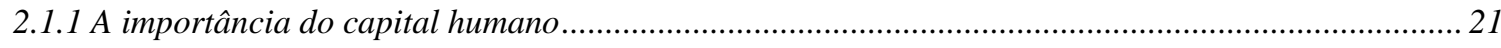

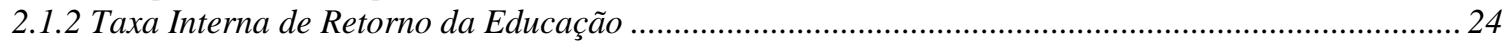

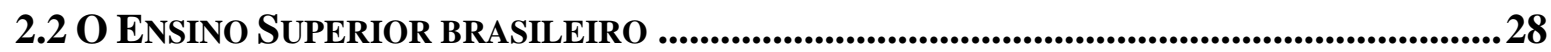

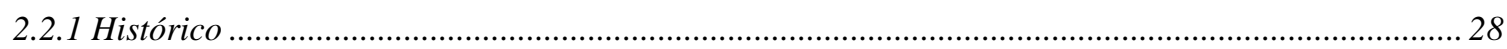

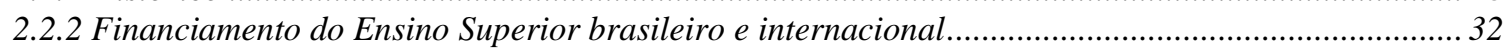

2.2.3 Áreas estratégicas do Ensino Superior para o desenvolvimento econômico e o caso do Brasil ......... 35

3 PROGRAMA NACIONAL DE ASSISTÊNCIA ESTUDANTIL ....................................42

3.1 REIVINDICAÇÕES POR ASSISTÊNCIA ESTUDANTIL .............................................................42

3.2 Programa Nacional de AssistênCia Estudantil: O FORTAlecimento da

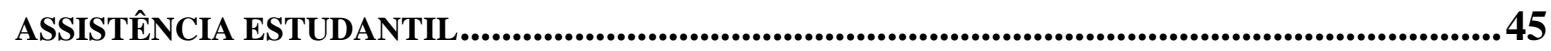

3.3 PERFIL SOCIOECONÔMICO DOS ESTUDANTES DAS INSTITUIÇÕES FEDERAIS DE ENSINO

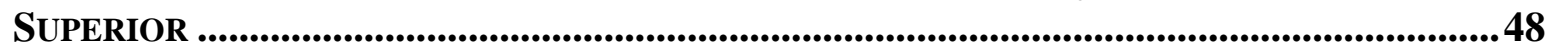

3.4 Matriz de distribuição orÇAMentária do Programa NaCional de

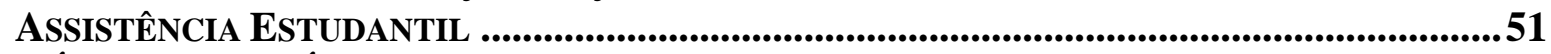

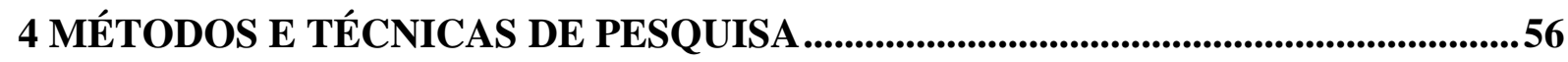

4.1 TIPO E DESCRIÇÃO DA PESQUISA ....................................................................................56

4.2 CARACTERIZAÇÃO do LóCUS DA PESQUISA ....................................................56

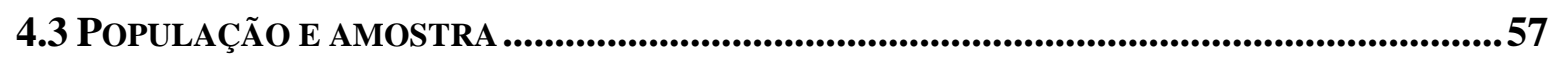

4.4 PROCEDIMENTOS DE COLETA DOS DADOS DA PESQUISA ...............................................58

4.5 INSTRUMENTOS DE COLETA DOS DADOS DA PESQUISA ................................................58

4.6 PROCEDIMENTOS DE ANÁLISE dOS DAdOS ...........................................................59

4.7 SÍNTESE METODOLÓGICA ..........................................................................................60

5 O PLANO NACIONAL DE ASSISTÊNCIA ESTUDANTIL NA UNIVERSIDADE DE

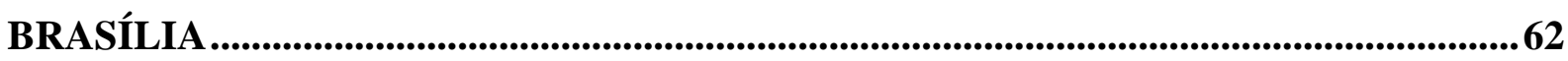

5.1 A ASSISTÊNCIA ESTUDANTIL NA UNIVERSIDADE DE BRASÍLIA ...............................62

5.2 PERFIL dOS ESTUdANTES ASSISTIDOS PELA UNIVERSIDAdE DE BRASÍLIA...................72

5.3 TRANCAMENTO DE MATRÍCULAS E DESLIGAMENTO ESTUDANTIL DA UNIVERSIDADE DE

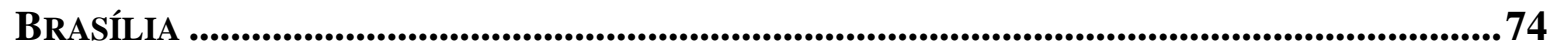


6 CONCLUSÃ

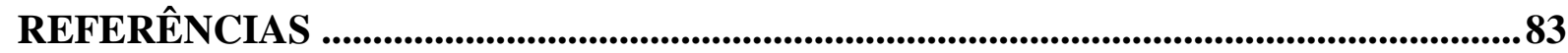

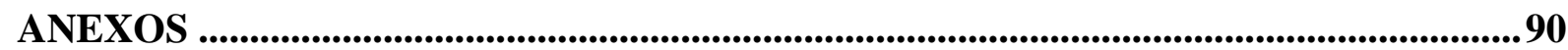

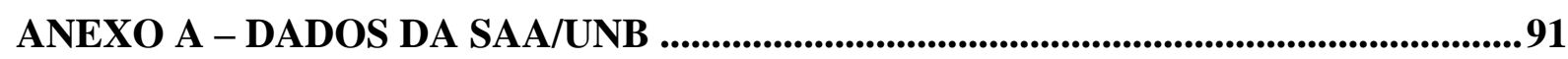

ANEXO B - DADOS DA ASSISTÊNCIA ESTUDANTIL..................................................99 


\section{INTRODUÇÃO}

\subsection{Considerações iniciais}

O Programa Nacional de Assistência Estudantil (PNAES) tem a finalidade de ampliar as condições de permanência de estudantes de baixa renda nas Instituições Federais de Ensino Superior (IFES) e promover a inclusão social por meio da educação.

De acordo com a última pesquisa do Programa das Nações Unidas para o Desenvolvimento (PNUD) (2013), o Brasil tem sua classificação no grupo de países com alto desenvolvimento humano e permanece na $85^{\text {a }}$ posição do Índice de Desenvolvimento Humano $(\mathrm{IDH})^{1}$; porém, quando se trata de distribuição de renda, medido pelo Índice de Gini, o país se encontra entre os 13 piores do planeta. Além disso, apresenta baixa mobilidade social e educacional.

O Instituto de Pesquisa Econômica Aplicada (IPEA) (SOARES, F. et al., 2006) aponta que os programas de distribuição de renda foram extremamente importantes para a redução das desigualdades sociais no Brasil. Neste sentido, para Cardoso (2006), o capital humano é extremamente relevante, o que caracteriza a educação como um investimento e que provoca impactos positivos na economia, além de minimizar as desigualdades sociais existentes no país. E ainda, Veloso (apud BACHA; SCHAWARTZMAN; MEDICI, 2011) afirma que os programas bem sucedidos de intervenção educacional em ambientes socioeconômicos desfavoráveis possuem externalidades positivas superiores aos custos.

Para o IPEA (2011), o efeito multiplicador econômico no incremento de $1 \%$ do Produto Interno Bruto (PIB) brasileiro em gastos sociais aumenta 1,37\% neste quesito e, o investimento em educação retornaria com acréscimo de $1,85 \%$ ao PIB, mostrando-se ainda mais vantajoso quando aplicado nesta modalidade. Neste sentido, Cavalcanti, Gomes e Pereira (2001) destacam que 55\% da riqueza produzida no mundo advém de áreas de conhecimento específico, tais como: inovação tecnológica, patentes e engenharias, a outra parte, $45 \%$, é da fórmula tradicional: capital, trabalho e terra.

Davenport (1998) reconhece que os aspectos intangíveis que adicionam valor aos produtos e serviços são todos baseados em: conhecimento, habilidade técnica, projeto de produto, apresentação de marketing, criatividade e inovação. Ao contrário de ativos materiais que se depreciam à medida que são utilizados, o ativo do

\footnotetext{
${ }^{1}$ O Índice de Desenvolvimento Humano (IDH) mede o progresso de uma nação a partir de três dimensões: renda, saúde e educação. O referido índice varia de 0 a 1 . Quanto mais próximo de 1, maior o desenvolvimento humano.
} 
conhecimento é ilimitado, pois cresce quando é estimulado e utilizado: ideias geram novas ideias e o conhecimento compartilhado permanece com a sua fonte, bem como com seu receptor (MARTINS, 2009, p. 4).

A União é o principal financiador do Ensino Superior público brasileiro. A fim de propiciar o aumento da oferta de vagas neste modal de ensino, foi criado, em 2007, o Programa de Reestruturação das Universidades Federais (REUNI). Com o advento deste, o PNAES foi implementando por meio da Portaria Normativa $n^{\circ} 39$ do Ministério da Educação (MEC), tornando-se política governamental por meio do Decreto Presidencial no 7.234/2010. O Estado, como ente de democratização e socialização dos indivíduos desfavorecidos economicamente, promulgou a Lei $\mathrm{n}^{\circ}$ 12.711/2012, que dispõe 50\% das vagas das IFES para estudantes que cursaram o Ensino Médio em escolas públicas. De acordo com o Fórum Nacional de Pró-Reitores de Assuntos Comunitários e Estudantis (2004), 65\% dos estudantes universitários necessitam de algum apoio institucional para sua manutenção na universidade, e 42,8\% vivem em risco de vulnerabilidades socioeconômicas.

\begin{abstract}
A discussão sobre a Assistência Estudantil é de grande relevância, o Brasil é um dos países em que se verifica as maiores taxas de desigualdades sociais, fato visível dentro da própria universidade, onde um grande número de alunos que venceram a difícil barreira do vestibular já ingressou em situação desfavorável frente aos demais, sem ter as mínimas condições socioeconômicas de iniciar, ou de permanecer nos cursos escolhidos. Além do que, percebemos que a Assistência Estudantil pode ser trabalhada sob diferentes perspectivas: de um lado como direito, e de outro, como investimento (ARAÚJO, J., 2003, p. 99).
\end{abstract}

A tentativa de democratização do Ensino Superior no Brasil trouxe ao Estado novos desafios, como, por exemplo, o de ofertar as condições necessárias para a conclusão do curso aos estudantes acometidos por vulnerabilidades socioeconômicas. Neste sentido, o PNAES é o instrumento facilitador para que estes permaneçam nas universidades e concluam seus cursos, minimizando, assim, a evasão no Ensino Superior público federal. Compreende-se daqui e, de acordo com Albuquerque, Medeiros e Silva (2013), que o referido Programa apresenta as funções alocativa e distributiva, ou seja, o governo ofertando serviços públicos (no caso, a educação) e distribuição de renda por meio de benefícios do PNAES.

A Assistência Estudantil superior é um conjunto de programas e mecanismos de estímulos à permanência e a conclusão dos cursos dos estudantes que se encontram em vulnerabilidades socioeconômicas. Este tem a finalidade de promover a justiça social e dar igualdade de condições de estudos a todos os estudantes. 
A formação de capital humano, em especial, dos estudantes assistidos, pode promover a ascensão social destes, contribuindo para o fortalecimento do crescimento nacional, sobretudo, se os referidos discentes forem direcionados às áreas consideradas estratégicas pela Pesquisa Industrial de Inovação Tecnológica (PINTEC) para o desenvolvimento do país.

Como análise da temática em questão, as linhas aqui empreendidas foram direcionadas na Universidade de Brasília (UnB), dividida em quatro campus, a saber: Darcy Ribeiro, Faculdade UnB Ceilândia (FCE), Faculdade UnB Gama (FGA) e Faculdade UnB Planaltina (FUP), constatando-se que em todos campi existem estudantes beneficiados pelo PNAES.

Diante do exposto, indagou-se como o PNAES pode contribuir para a diplomação de grau dos estudantes que participam dos programas da Diretoria de Desenvolvimento Social do Decanato de Assuntos Comunitários (DDS/DAC) da referida Universidade, além de colaborar com a diminuição das desigualdades sociais e o aumento do desenvolvimento nacional, a partir da formação de capital humano.

\subsection{Formulação do problema}

O IPEA (2011) afirma que a política social com base na transferência de renda e a educação são responsáveis por grande parte do crescimento econômico e a diminuição das desigualdades sociais no Brasil.

Para Descy e Tessaring (2006), a educação é um fator primordial para a promoção social, o que transcende a característica individual, gerando fatores externos positivos para a sociedade, como, por exemplo, a redução da desigualdade social e o impulso do crescimento e do emprego.

Ao se comparar a educação brasileira com a educação internacional, é possível identificar em que áreas os países desenvolvidos estão concentrando os seus esforços, bem como as lacunas existentes no Brasil. A formação de capital humano pode melhorar a atividade produtiva do trabalhador e gerar crescimento para o país por meio do conhecimento e da capacidade inovativa.

O Brasil é um dos piores países no que tange à questão do índice de distribuição de renda do mundo. Mas é preciso reconhecer que o Estado interfere na economia e na educação com ações programáticas, com o propósito de diminuir as lacunas existentes na sociedade brasileira, ofertando um Ensino Superior gratuito e programas de manutenção dos estudantes. Devido à enorme desigualdade social, o Fórum Nacional de Pró-Reitores de Assuntos Comunitários e Estudantis (FONAPRACE) (2011) afirma que grande parte dos matriculados 
nas IFES necessitam de algum tipo de ajuda para sua manutenção nos cursos superiores, e a ação governamental para suprir tal necessidade se dá com o auxílio do PNAES.

Neste sentido, em 12 de dezembro de 2007, o MEC, por meio da Portaria Normativa $\mathrm{n}^{\text {o }} 39$ instituiu o PNAES e, em 19 de julho de 2010, foi publicado o Decreto Presidencial $\mathrm{n}^{\circ}$ 7.234, que dispõe sobre o referido Programa, convertendo-se em política de governo.

O PNAES, em seu primeiro ano de ação (2008), disponibilizou cerca de R\$ 100.000.000,00 (cem milhões de reais) para as IFES e, após seis anos de sua implementação, em 2014, foi disponibilizado algo em torno de $\mathrm{R} \$ 742.000 .000,00$ (setecentos e quarenta e dois milhões de reais). O aporte orçamentário empregado pelo Governo Federal para a manutenção do Programa cresceu mais de 700\% (BRASIL, 2014). Diante do crescimento orçamentário faz-se importante verificar a distribuição orçamentária nos níveis nacional e regional, bem como o número de benefícios concedidos por aquele Programa.

Em suma, a finalidade do PNAES é diminuir a evasão do Ensino Superior para que os estudantes economicamente vulneráveis matriculados nas IFES possam concluir a graduação, minimizando os efeitos das desigualdades sociais e regionais na educação superior e promovendo a inclusão social pela educação.

Após a análise macro do PNAES, as linhas que se seguem analisaram em nível micro, ou seja, o caso específico da UnB, a aplicação dos recursos supramencionados (quantos estudantes são atendidos e quais os benefícios ofertados são financiados pelo PNAES etc), o que permitiu conhecer os principais entraves e desafios de aplicabilidade das ações de Assistência Estudantil da UnB.

Assim, tem-se aqui uma proposta de verificação do cumprimento dos objetivos do PNAES na UnB, a saber: reduzir a evasão universitária e evitar o desperdício de recursos públicos.

\subsection{Objetivos}

\subsubsection{Objetivo geral}

Analisar na perspectiva econômica o PNAES na UnB.

\subsubsection{Objetivos específicos}

- Comparar os investimentos da educação em relação ao PIB de modo internacional. 
- Apresentar o histórico da Assistência Estudantil no Brasil.

- Identificar os programas de auxílio aos estudantes existentes na UnB.

- Mensurar os benefícios ofertados pela Assistência Estudantil da UnB.

- Identificar em que cursos os estudantes auxiliados encontram-se matriculados.

- Mensurar a evasão de estudantes antes e após a implementação do PNAES.

\subsection{Justificativa}

O PNAES visa garantir a manutenção dos estudantes economicamente vulneráveis nas IFES, a fim de que estes possam concluir as suas graduações presenciais, proporcionando melhores oportunidades de ascensão social. Neste sentido, é possível analisar se o referido Programa tem sido exitoso na UnB ao mensurar o percentual geral de formados e o nível de evasão estudantil.

Ao analisar em que cursos os estudantes da UnB que são beneficiados pela Assistência Estudantil estão matriculados, é possível identificar o percentual de estudantes matriculados em cursos orientados para o desenvolvimento econômico brasileiro.

Assim, o presente estudo busca contribuir e sinalizar para as decisões de políticas públicas no que tange à distribuição dos recursos orçamentários da União que serão aplicados na educação de Ensino Superior público brasileiro para a manutenção de estudantes vulneráveis economicamente, com ênfase no desenvolvimento econômico nacional. 


\section{REFERENCIAL TEÓRICO}

\subsection{Capital humano}

\subsubsection{A importância do capital humano}

Para Schultz (1973), entende-se por capital humano o conjunto de capacidade, conhecimentos, competências e atributos de personalidade que favorecem a realização de trabalho, de modo a produzir valor econômico.

A capacidade de iniciativa, a competência profissional, a inventividade, a disciplina e o hábito de agir no presente tendo em vista o futuro são fatores de produção pelo menos tão importantes para a criação de riqueza quanto qualquer outro tipo de capital (FONSECA apud MARTINS, 2009, p. 3).

A capacitação de pessoas tem como finalidade fortalecer a vantagem competitiva, tornando-as mais aptas à inovação e produzir com qualidade os produtos e serviços ofertados.

Davenport e Prusak (1999) afirma que o capital humano na forma de conhecimento é um bem intangível e não depreciável, sendo este ilimitado, uma vez que todos os bens e serviços existentes foram criados e inovados por pessoas motivadas em criatividade, habilidade e conhecimento.

Neste sentido, o conhecimento pode ser definido em quatro categorias, conforme expresso no Quadro 1, a seguir.

Quadro 1 - Tipos de conhecimento.

\begin{tabular}{|l|l|l|l|}
\hline Conhecimento Popular & \multicolumn{1}{|c|}{$\begin{array}{c}\text { Conhecimento } \\
\text { Científico }\end{array}$} & \multicolumn{1}{|c|}{$\begin{array}{c}\text { Conhecimento } \\
\text { Filosófico }\end{array}$} & Conhecimento Religioso \\
\hline Valorativo & Real (factual) & Valorativo & Valorativo \\
\hline Reflexivo & Contingente & Racional & Inspiracional \\
\hline Assistemático & Sistemático & Sistemático & Sistemático \\
\hline Verificável & Verificável & Não verificável & Não verificável \\
\hline Falível & Falível & Infalível & Infalível \\
\hline Inexato & Aproximadamente exato & Exato & Exato \\
\hline
\end{tabular}

Fonte: Ferrari (1974, p. 11). 
Segundo Loureiro (2005), o capital humano é o principal fator para a construção de empresas mais lucrativas, economias mais igualitárias e formação de um mundo mais justo e humano.

Para Chiarini e Viana (2012), o capital humano é um dos principais fatores para o desenvolvimento de uma economia. Por meio do conhecimento, os indivíduos poderão aumentar a capacidade produtiva e colaborar para o desenvolvimento econômico do país e diminuir as desigualdades sociais.

Becker (1993) já intitulava que o capital humano é o conjunto de capacidades produtivas das pessoas e que deve ser utilizado na produção de riqueza de um país.

A Teoria do Capital Humano investiga como o conhecimento pode influenciar o crescimento econômico de um país. Esta tem em suas primícias que a educação torna os indivíduos mais produtivos, aumenta suas rendas e colabora para o crescimento econômico nacional.

Solow (1956) afirma que até a década de 1950, o crescimento se dava em função dos fatores tradicionais existentes em um país ou região, a saber: matéria prima, capital e trabalho.

Os primeiros indícios sobre a responsabilidade do conhecimento para o crescimento de um país surgem com Schutz, em meados de 1960, em um artigo publicado no The Journal of Political Economy, onde se versou que a educação é uma forma de investimento, pois, o conhecimento se torna pertencente à pessoa e, portanto, seria uma forma de capital humano aspecto reforçado por Gary Becker (1962), com o trabalho Capital Humano, onde afirma que o conhecimento pode proporcionar bem estar e aumento de renda futuros, enquanto aqueles que não se preocupam com tal modalidade de investimento têm impactos presentes e perdas futuras devidos aos custos da educação.

Para a afirmação da referida teoria, Mincer (1974), responsável pela equação Minceriana, revela que quanto mais anos de escolaridade, maior será a renda do indivíduo, cujo crescimento se dará de forma linear, enquanto que a experiência é quadrática, cresce até certo instante e declina com o envelhecimento da pessoa.

Mesmo quando ainda não se tinha o termo "capital humano", Adam Smith (1776), em sua obra Riqueza das Nações, defendia a educação para o desenvolvimento econômico, sendo assim, um estudo de base para a referida teoria (CUNHA, 2007).

De fato, todo investimento possui custo; inclusive, a educação. Para o custo de oportunidade (trade-off), o investidor deverá escolher a opção que lhe será mais benéfica, ou seja, aquela em que os resultados serão melhores que os custos. O custo de oportunidade é o estudo e a criação de capital humano, mas tem-se aí uma menor autonomia financeira por 
parte do investidor, bem como a diminuição de suas horas de lazer, pois está dedicando parte do seu tempo e recursos aos estudos, além de diminuir o seu poder de consumo no tempo presente; por outro lado, o não investimento em educação aumentará o poder econômico presente do indivíduo, mas sua renda futura provavelmente estará estagnada. Neste sentido, Schultz (1973) sustenta que o investimento em capital humano é o responsável pelo aumento de renda dos trabalhadores. Para ratificar a afirmação, Becker (1993) relata em suas pesquisas que a educação e o treinamento são responsáveis pelas diferenças salariais - as pessoas educadas ganham mais, e tal fato é visível com maior expressividade em países em desenvolvimento.

A educação pode ser considerada investimento (quando os benefícios veem posteriormente, como, por exemplo, maior produção no trabalho, capacidade intelectual aumentada e alteração positiva no nível de renda) ou consumo (quando a educação é considerada somente despesa social que traz benefícios imediatos sem perspectiva de melhorias futuras) ou os dois aspectos simultaneamente (CUNHA, 2007).

Neste sentido, têm-se cinco pressupostos que a educação pode promover ao indivíduo, quais sejam:

1) retorno financeiro;

2) retorno da opção financeira, que se entende por obtenção de mais educação e a recompensa que a acompanha;

3) variáveis não monetárias como opção, como, por exemplo, a escolha de empregos;

4) adaptabilidade a novas tecnologias, uma vez que as pessoas mais educadas são mais propensas a aceitação tecnológica; e

5) benefícios de não fazer uso do mercado indiretamente relacionado às condições de emprego (WEISBROD, 1962).

A educação aumenta o nível de bem-estar daquele que se educa e permeia também este nível para as pessoas que os circulam. A educação promove o crescimento salarial, da produtividade, aumenta a expectativa de vida e reduz o tamanho da família, da mortalidade, diminuindo o índice de pobreza para o futuro. O investimento na educação facilitará o crescimento socioeconômico e o Produto Interno Bruto (PIB) per capita no país (SOARES S., 2006).

De fato, os investimentos em capital humano são estratégicos para o crescimento econômico de um país. 
O nível de capital humano de uma população influencia o sistema econômico de diversas formas, com o aumento da produtividade, dos lucros, do fornecimento de maiores conhecimentos e habilidades, e também por resolver problemas e superar dificuldades regionais, contribuindo com a sociedade de forma individual e coletiva (VIANA, 2010, p. 139).

O capital humano tem-se se tornando cada vez mais fator primordial na determinação de produção de um país. Crawford (1994) sustenta que os países melhores posicionados em termos econômicos têm como base o desenvolvimento de pessoas.

\subsubsection{Taxa Interna de Retorno da Educação}

O nível educacional da população adulta de um país é o resultado de décadas de investimento em educação, da mesma forma que o estoque de capital físico da economia é o resultado de décadas de investimento em máquinas, equipamentos e infraestrutura (IPEA, 2011, p. 6).

A determinação individual para se investir em estudos no Brasil ainda é pequena, principalmente se o indivíduo possui baixa escolaridade, uma vez que o retorno do investimento pode demorar e diminuir substancialmente o seu bem estar durante aquele período. Nos níveis de escolaridade mais altos, a iniciativa de investimento eleva-se devido à expectativa de retorno ser mais alta. O Brasil não possui uma pesquisa ou gerenciamento para acompanhar o indivíduo ao longo do tempo, o que dificulta o tema estudado (SACHSIDA; LOUREIRO; MENDONÇA, 2004).

O sistema educacional é indicado como um dos fatores de desenvolvimento de um país e, tradicionalmente, a taxa de retorno da educação no Brasil é estimada nas regressões de Mincer, onde o coeficiente da educação tem como prêmio o salário igual à taxa de retorno da educação.

A equação minceriana exerce forte influência sobre os pesquisadores que estudam o retorno do investimento sobre a educação. Tal equação implica que a renda de uma pessoa é dependente principalmente dos fatores "educação" e "experiência" (MARCELO; WYLLIE, 2006).

Mincer propôs um modelo para estimar os retornos da educação, da qualidade da educação, das experiências, do gênero, da raça e da região - aspectos que podem interferir na renda das pessoas. A Taxa Interna de Retorno (TIR) é aquela que verifica o custo de capital com o ganho esperado pelo investimento - neste caso, a educação. Tal modelo também é 
utilizado para medir a transversalidade entre o crescimento econômico e o nível de escolaridade, além de verificar os efeitos sobre a desigualdade (MINCER, 1974).

O modelo de regressão de Mincer é composto da seguinte fórmula:

$\ln \mathrm{w}=\beta 0+\beta 1$ educ $+\beta 2 \exp +\beta 3 \exp ^{2}+\gamma^{\prime} \mathrm{x}+\epsilon$

onde:

- $\quad \mathrm{w}=$ salário recebido pelo indivíduo;

- $\quad$ educ = escolaridade do indivíduo, geralmente medida por anos de estudo;

- $\exp =$ experiência do indivíduo, geralmente aproximada pelo idade do indivíduo;

- $\quad \mathrm{x}$ = vetor de características observáveis do indivíduo, tais como: raça, gênero, região; e

- $\epsilon=$ erro estocástico.

A técnica elaborada por Mincer quantifica a TIR da educação, que mede os diferentes níveis de renda para diferentes escalas de escolaridade, e possui também outros fatores que podem comprometer ou influenciar a renda a ser adquirida, tais como: região, gênero, raça, habilidades e outros (BECKER, 1993).

Mincer (1981) vislumbra que o capital humano pode ser observado pela ótica macroeconômica quando seus pressupostos são indispensáveis para o crescimento econômico do país, e pela percepção microeconômica, onde a diferença de estoque de capital humano é uma das variáveis responsáveis pela estrutura salarial e distribuição de renda pessoal.

Para Cangussu, Salvato e Nakabashi (2010), a especificação proposta por Mincer é mais adequada para o estudo do caso brasileiro. Ainda conforme aqueles autores, o impacto do capital humano no PIB per capita é maior que o impacto do capital físico.

Teixeira e Menezes-Filho (2012) consideram que Langoni (1973) foi o pioneiro no estudo da TIR sobre o investimento na educação brasileira; este autor certifica que a escolaridade é fator significativo para as diferenças salariais e para as desigualdades sociais existentes no Brasil.

Para avaliar se o investimento na educação brasileira era rentável, Langoni, em 1973, desenvolveu um trabalho sobre a TIR do investimento em capital fixo e a TIR em educação, e concluiu que nas décadas de 1960 e 1970, a TIR em educação era superior aos rendimentos do capital fixo. Em 1969, aquele autor subdividiu a TIR por nível de ensino, do seguinte modo: 
primário (32\%); fundamental (19,5\%); médio (21,3\%); e, superior (12,2\%) (BARBOSA FILHO; PESSÔA, 2008).

Conforme Sachsida, Loureiro e Mendonça (2004), outros autores trabalharam na TIR da educação brasileira, a saber:

- Ueda e Hofmann (2002) fizeram uso do método de variáveis instrumentais, apresentando o percentual de $9,8 \%$.

- Loureiro e Galrão (2001) utilizaram o artifício de Heckman nos setores rurais e urbanos, apresentando o percentual de $18,58 \%$ e $11,35 \%$, respectivamente.

- Silva e Kassouf (2000) investigaram a existência de retornos diferenciados por sexo na escolaridade e treinamento, onde afirmaram que o retorno da escolaridade para as mulheres foi maior que a dos homens.

- Soares e Gonzaga (1999) utilizaram o modelo de switching-regressions, que definiu a TIR da seguinte maneira: setor secundário: $12 \%$; setor primário: $23,4 \%$.

Teixeira e Menezes-Filho (2012, p. 485) destacam que estes "trabalhos encontram um diferencial de salários significativo associado à educação e enfatizam a necessidade de se investir nos estágios iniciais da educação, pois a taxa de retorno era bem mais elevada" que os níveis imediatamente superiores.

O comportamento salarial do brasileiro é dado por meio do ensino e de sua experiência. Para aqueles que possuem zero ano de estudo, o salário é refletido em forma de "U" invertido, inicialmente o salário vai crescendo nos primeiros anos de trabalho, decaindo posteriormente, o que pode ser interpretado como depreciação do conhecimento. Para os detentores de ensino com até o primeiro grau, o crescimento salarial é linear e cresce conforme o ganho de experiência. Para portadores do Ensino Médio e Superior, o ângulo da curva da taxa salarial é decrescente com os anos de experiência. De todo modo, infere-se que a inclinação das curvas de salários se eleva com os anos de educação (BARBOSA FILHO; PESSÔA, 2008). 
Tabela 1 - Salário médio.

\begin{tabular}{lccc}
\hline Nível de Escolaridade & \multicolumn{2}{c}{ Pessoal Ocupado Assalariado } & \multirow{2}{*}{$\begin{array}{c}\text { Salário Médio Mensal } \\
\text { em Reais (R\$) }\end{array}$} \\
\cline { 2 - 3 } & Absoluto & Relativo (\%) & \\
\hline Sem nível superior & 37.445 .402 & 82,9 & $1.294,70$ \\
Com nível superior & 7.738 .617 & 17,1 & $4.135,06$ \\
\hline
\end{tabular}

Fonte: IBGE (2013).

Barbosa Filho e Pessôa (2008) realizaram pesquisa semelhante à de Langoni (1973), no intuito de atualizar e comparar o retorno da educação em períodos distintos, conforme expresso na Tabela 2, a seguir.

Tabela 2 - Comparativo da TIR sobre Educação.

\begin{tabular}{lccc}
\hline \multicolumn{1}{c}{ Escolaridade } & $\mathbf{1 9 6 0}$ & $\mathbf{1 9 6 9}$ & $\mathbf{2 0 0 4}$ \\
\hline Pré-escola & 48,1 & 32 & 9,8 \\
Primário & 23,8 & 19,5 & 14,8 \\
Secundário & 14,8 & 21,3 & 13,9 \\
Terciário & 4,9 & 12,2 & 13,8 \\
\hline
\end{tabular}

Fonte: Barbosa Filho e Pessôa (2008, p. 110).

Todos os níveis educacionais oferecem retorno aos indivíduos. O comparativo outrora apresentado demonstra que o período do primeiro ano de estudo até à pré-escola oferecia maior retorno sobre a TIR da educação e, na atualização destes dados, demonstrou-se este nível como o de maior queda sobre a TIR. Todos os níveis de educação sofreram queda na taxa de retorno, com exceção do terceiro grau, que demonstrou fôlego e ofertou crescimento maior que os anos anteriores do estudo.

De acordo com Sachsida, Loureiro e Mendonça (2004, p. 263), o Estado deve investir principalmente nos níveis mais elementares da educação, pois, um indivíduo ou família de baixa renda não "estaria propensa a investir em educação porque teria que suportar um custo muito alto gerado pelo baixo retorno até que o investimento se tornasse atrativo".

A TIR da educação no Brasil continua muito rentável e o investimento no setor ainda é muito viável, além de gerar externalidades positivas - maior desenvolvimento social e econômico. Neste sentido, é possível destacar a educação superior por apresentar crescimentos sucessivos da TIR, bem como oferecer melhor média salarial que os níveis educacionais anteriores. 


\subsection{O Ensino Superior brasileiro}

\subsubsection{Histórico}

O Brasil Colônia era visto pela Coroa Portuguesa como se fosse uma empresa e, portanto, era tratado como um local de investimento para a obtenção de lucros. Portugal não tinha interesse em educar o povo brasileiro, pois este poderia conquistar sua autonomia e se rebelar contra a Coroa Portuguesa. O Ensino Superior brasileiro teve sua origem somente no século XIX, em 1808, quando a Família Real Portuguesa se viu obrigada a se transferir para a Colônia, em consequência das ameaças napoleônicas de invadir Portugal. A descentralização do Ensino Superior no Brasil só foi possível após a Proclamação da República, em 1889, quando também se alterou a Constituição da época - fato importantíssimo, pois, ali se diversificou o sistema educacional brasileiro valido até o presente momento (SANTOS; CERQUEIRA, 2011).

No segundo momento, durante o golpe da Revolução de 1930, o ensino retoma as características monárquicas, com a centralização por parte do Estado e a criação do Ministério da Educação (MEC), por intermédio do Decreto n 19.444, de 01 de dezembro de 1930.

Durante a Segunda República (1945-1964), expandem-se as universidades federais e surgem as universidades estaduais e municipais. Neste período tem-se a Campanha Nacional de Aperfeiçoamento de Pessoal de Nível Superior (atualmente Coordenação de Aperfeiçoamento de Pessoal de Nível Superior - CAPES), por meio do Decreto $\mathrm{n}^{\circ}$ 29.741/1951, e a União Nacional dos Estudantes (UNE), que reivindicava toda a substituição da rede de ensino privada. Em 1961, foi aprovada a primeira Lei de Diretrizes e Bases da Educação (LDB), que possuía, entre suas funções, mecanismos de controle da expansão do Ensino Superior (SANTOS; CERQUEIRA, 2011).

De acordo com Sampaio (1991), o movimento estudantil foi derrotado durante o Regime Militar (1964-1985), sendo este o detentor do controle das universidades. Em 1968, foi anunciada a reforma do Ensino Superior preconizada por Darcy Ribeiro, cujas principais mudanças eram: abolir a cátedra e implementar os departamentos, organizar os currículos em duas etapas: o básico e o profissionalizante, e deliberar a flexibilidade curricular com o sistema de crédito e semestralidade. E ainda, segundo Sampaio (1991), a expansão universitária tem sua gênese em 1960 e se intensifica na década de 1970. 
Durante a década de 1970, se deu o chamado "milagre econômico", que promoveu o enriquecimento da classe média e, consubstancialmente, o aumento da demanda pelo Ensino Superior. O setor público não estava preparado para ofertar as vagas necessárias para este modal de ensino. O setor privado absorveu grande parte desta demanda, tornando o Ensino Superior um grande negócio. Neste sentido, o Ensino Superior privado, em 1986, era responsável por $76,5 \%$ das matrículas, a rede federal por $16 \%$, e as redes estadual e municipal por 7,5\% das matrículas efetivadas (SANTOS; CERQUEIRA, 2011).

Em 1996, foi promulgada a nova LDB - em vigor desde a sua publicação. Ali se tem como destaque a obrigatoriedade do recredenciamento das Instituições Federais de Ensino Superior (IFES), a criação do Exame Nacional dos cursos e a criação do Exame Nacional do Ensino Médio (ENEM), além da autonomia universitária das instituições de Ensino Superior. O Plano Nacional de Educação, em 2001, estabeleceu como meta matricular entre $12 \%$ e 30\% dos jovens de 18 a 24 anos no nível superior. Mas o referido índice estava abaixo de países com economia inferior, como, por exemplo, a Argentina (40\%) e o Chile (20,6\%).

De acordo com o Instituto Nacional de Estudos e Pesquisas Educacionais Anísio Teixeira (INEP), as instituições de Ensino Superior brasileiro e o número de matriculados estão distribuídos conforme as Tabelas 3 e 4, a seguir.

Tabela 3 - Número de instituições de Ensino Superior.

\begin{tabular}{lcccccccccccc}
\hline \multicolumn{10}{c}{ Número de Instituições de Ensino Superior em 2011 no Brasil } \\
\hline \multicolumn{10}{c}{ Total Geral } & \multicolumn{10}{c}{ Pública } \\
\hline \multicolumn{1}{l}{ Total } & $\%$ & Total & $\%$ & Federal & $\%$ & Estadual & $\%$ & Municipal & $\%$ & Total & $\%$ \\
\hline 2365 & 100 & 284 & 12 & 103 & 4,3 & 110 & 4,7 & 71 & 3 & 2081 & 88 \\
\hline
\end{tabular}

Fonte: Brasil (2014). 
Tabela 4 - Número de matrículas de graduação em 2011.

\begin{tabular}{lcc}
\hline \multicolumn{3}{c}{ Número de Matrículas em 2011 nos cursos de graduação } \\
\hline Setor & Total & $\%$ \\
\hline Federal & 1032936 & 15,3 \\
Estadual & 619354 & 9,2 \\
Municipal & 121025 & 1,8 \\
Total Pública & 1773315 & 26,3 \\
Privada & 4966374 & 73,7 \\
Total & 6739689 & 100 \\
\hline
\end{tabular}

Fonte: Brasil (2014).

Conforme os dados apresentados nas Tabelas 3 e 4, o Ensino Superior Brasileiro concentra-se na iniciativa privada, sendo que a rede federal absorve apenas $15 \%$ dos graduandos. A educação, em especial, o nível superior, é considerada por muitos como forma de ascensão social. As vagas ofertadas no Ensino Superior público são limitadas e, apesar do modelo ali existente ser considerado público, o direito pela vaga é extremamente rival e excludente, o que contraria a definição de bens públicos.

Diante do fato de concentrar o número de matriculados do Ensino Superior na rede privada e o Estado não possuir infraestrutura adequada para ofertar o número de vagas necessárias para suprir a demanda estudantil do nível superior, em 2004, foi criado o Programa Universidade para Todos (ProUni), institucionalizado em 2005 por meio da Lei n $^{\circ}$ 11.096. Este tem a finalidade de ofertar bolsas integrais e parciais (50\%) em instituições privadas de Ensino Superior, em cursos de graduação e sequenciais para brasileiros não portadores de diploma superior; em contrapartida, a instituição recebedora dos discentes apoiados pelo Programa está isenta de tributos. Podem participar do ProUni os estudantes da rede pública ou da rede privada nas condições de bolsistas integrais e ter renda familiar per capita de até três salários mínimos (BRASIL, MEC, 2014).

Para Costa (2013, p. 2), o ProUni surge do "contexto da demanda de ampliação do acesso à Educação Superior no Brasil, em especial, por parte de segmentos sociais excluídos do sistema educacional, em função das dificuldades de ingressar na universidade" e manter-se até a colação de grau.

Sobre o ProUni, Costa (2013, p. 2) ainda assevera que:

$\mathrm{O}$ acesso às políticas públicas da juventude, em especial à educação superior, configura-se como uma possibilidade e uma perspectiva de mobilidade social ascendente, ao proporcionar oportunidades de capacitação profissional, acesso ao 
conhecimento e ampliação do universo cultural. Tais fatores podem contribuir para melhor inserção no mercado de trabalho e, consequentemente, uma elevação da renda desses indivíduos.

De acordo com Almeida Junior (2009), o ProUni não pode ser uma política isolada e deve oferecer ferramentas de manutenção do estudante na Instituição de Ensino Superior (IES). Para suprir tal necessidade, têm-se alguns incentivos, como, por exemplo, a Bolsa Permanência e os convênios para estágios com a Caixa Econômica Federal (CEF) e a Federação Brasileira de Bancos (FEBRABAN), entre outros.

Para o MEC (2014), o ProUni atendeu mais de 1,2 milhão de estudantes, desde sua criação até 2013 , sendo que $69 \%$ com bolsas integrais.

Heringer e Ferreira (2009) fazem algumas críticas ao ProUni, como, por exemplo, a renúncia de receita oferecida às IES conveniadas ao programa; ou seja, o Brasil deixa de arrecadar e, consequentemente, deixa de investir na educação pública.

Para suprir a demanda por vagas no Ensino Superior público foi criado, em 2007, o Programa de Reestruturação e Expansão das Universidades Federais (REUNI), que prevê a ampliação de acesso aos cursos de graduação, criação ou ampliação de cursos noturnos para melhor aproveitamento de espaço físico, e construção ou readequação da infraestrutura do Ensino Superior público federal. A Lei no 12.711, de 29 de agosto de 2012, como política de cunho afirmativa, dispõe que $50 \%$ das vagas das IFES deverão ser preenchidas por estudantes que cursaram integralmente o Ensino Médio em escolas públicas e, em seu parágrafo único, destaca ainda, que 50\% das referidas vagas deverão ser preenchidas por estudantes oriundos de famílias com renda per capita de até um salário-mínimo e meio, ou seja, estudantes em vulnerabilidades socioeconômicas.

\footnotetext{
A expansão de vagas e de Assistência Estudantil, ainda que focalizada, vão servir à coesão social e às ideologias de ascensão social via educação, num período de agudização das expressões da Questão Social, do desemprego estrutural e da desigualdade (CISLAGHI; SILVA, 2011, p. 9).
}

O Programa Nacional de Assistência Estudantil (PNAES) foi instituído em 2007 com o objetivo de garantir a permanência e a conclusão dos cursos de estudantes economicamente e socialmente vulneráveis, e com o advento da Lei de Cotas, que reserva 50\% das vagas para estes estudantes, o referido Programa deverá ser mais bem explorado pelo sistema com o objetivo de minimizar as desigualdades sociais e reduzir o abandono do Ensino Superior público federal. 


\subsubsection{Financiamento do Ensino Superior brasileiro e internacional}

A educação é um setor estratégico para o desenvolvimento econômico de um país. A principal fonte internacional de dados sobre a educação é a Organização para a Cooperação e Desenvolvimento Econômico (OCDE), responsável pelo teste do Programme for International Student Assessment (PISA), que mede a qualidade de ensino em diversos países. Neste sentido, Maciel (2013, p. 26) destaca: "No caso das despesas com educação, espera-se que países com perfil demográfico jovem, como o Brasil, tendam a alocar mais recursos no setor do que os demais países" com perfil demográfico mais velho.

A seguir, tem-se uma seguinte comparação em relação ao PIB em investimento na educação brasileira e internacional.

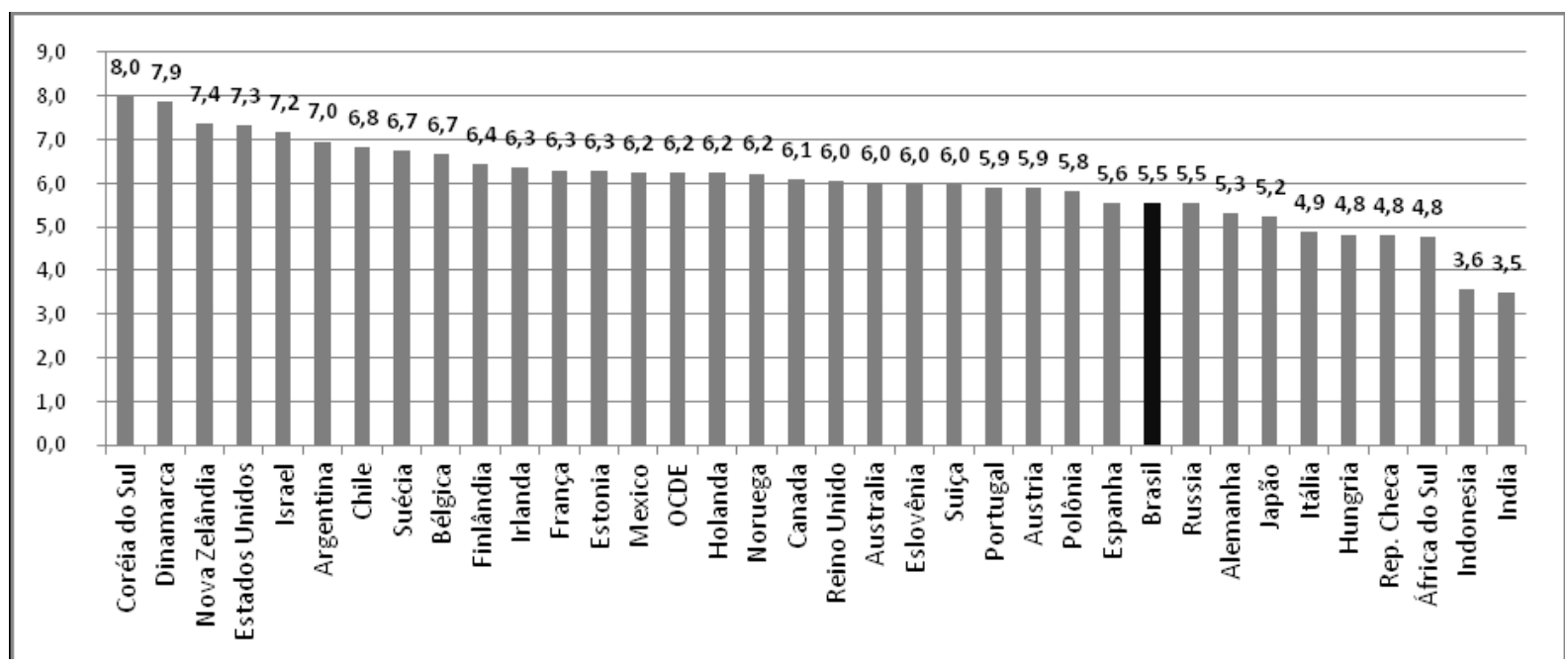

Gráfico 1 - Investimento na educação em relação ao Produto Interno Bruto brasileiro e internacional.

Fonte: OECD: Education at a Glance (2012 apud MACIEL, 2013).

Ao analisar a situação brasileira, o país encontra-se abaixo da média dos países que compõem a OCDE que aplicam 6,2\% do PIB. De acordo o Instituto de Pesquisa Econômica Aplicada (IPEA) (2011), o gasto público em educação saltou de R\$ 73,5 bilhões, em 1995, para R \$ 161,2 bilhões, em 2009, apontando um crescimento de mais de 119\%. Porém, tal fato se deu em proporção ao crescimento da economia nacional. Os dados da OCDE corroboram com o IPEA ao afirmarem que em 2012, o investimento estatal continuou na mesma proporção quando comparado ao PIB, em torno de 5,5\%. 
Segundo o teste do PISA (2012), o Brasil ocupa a $58^{\circ}$ posição no ranking da disciplina de Matemática entre os 65 países pesquisados. Apesar de ser uma colocação ruim, esta foi a única área em que o Brasil apresentou alguma melhoria, ou seja, saiu de 356 pontos, em 2003, para 391 pontos, em 2012. Ainda assim, o Brasil está aquém dos 494 pontos obtidos pela OCDE em 2012.

O investimento brasileiro na educação pré-escolar, primária e secundária é bem inferior aos aplicados pela OCDE, quando se assume o investimento per capita nos referidos níveis de educação. Neste sentido, os valores aplicados foram distribuídos conforme os dados expressos na Tabela 5, a seguir.

Tabela 5 - Investimento per capita por nível de ensino (US\$ - 1000).

\begin{tabular}{lcc}
\hline \multicolumn{1}{c}{ Nível Escolar } & OCDE & Brasil \\
\hline Pré-Escola & 6,7 & 1,7 \\
Primário & 7,7 & 2,4 \\
Secundário & 9,3 & 2,2 \\
Terciário & 13,7 & 11,7 \\
\hline
\end{tabular}

Fonte: OCDE Education at a Glance (2012 apud MACIEL, 2013).

De fato, o investimento na educação básica é bem inferior aos dos países desenvolvidos. A diferença no nível pré-escolar é de quatro vezes; no primário, de três vírgula vinte e uma vezes; e, no secundário, tem-se a maior discrepância: quatro vírgula vinte e duas vezes. O Ensino Superior é o único que se aproxima do investimento per capita da OCDE com diferença de $17 \%$.

A educação demanda recursos públicos, cumprindo, assim, as funções de distribuição e alocação de rendas. O financiamento da educação é garantido pela Carta Magna de 1888, em seu art. $211, \S 1^{\circ}$, in verbis:

Art. 211. A União, os Estados, o Distrito Federal e os Municípios organizarão em regime de colaboração seus sistemas de ensino.

$\S 1^{\circ}$ A União organizará o sistema federal de ensino e o dos Territórios, financiará as instituições de ensino públicas federais e exercerá, em matéria educacional, função redistributiva e supletiva, de forma a garantir equalização de oportunidades educacionais e padrão mínimo de qualidade do ensino mediante assistência técnica e financeira aos Estados, ao Distrito Federal e aos Municípios; (Redação dada pela Emenda Constitucional no 14, de 1996)

[...] (BRASIL, 1988). 
A LDB versa que os Municípios devem oferecer a educação infantil em creches e préescolas e, com prioridade, o Ensino Fundamental; e os Estados devem assegurar o Ensino Fundamental e oferecer, com prioridade, o Ensino Médio. Para a garantia de tal financiamento, a Carta Magna de 1988 assegura no seu art. 212, in verbis:

Art. 212. A União aplicará, anualmente, nunca menos de dezoito, e os Estados, o Distrito Federal e os Municípios vinte e cinco por cento, no mínimo, da receita resultante de impostos, compreendida a proveniente de transferências, na manutenção e desenvolvimento do ensino.

[...] (BRASIL, 1988).

Estes percentuais somente poderão ser atribuídos aos impostos recolhidos, não sendo compreendidas as taxas e contribuições. Em 2009, a Emenda Constitucional (EC) n 59 estabeleceu a exclusão gradativa dos gastos públicos em educação do cálculo da Desvinculação da Receita da União, o que poderá elevar os recursos para a educação.

O Brasil não dispõe de mecanismo de controle ou sistemas estatísticos que mensurem o investimento da iniciativa privada na educação superior, mas o investimento público neste nível de ensino representa $0,8 \%$ do PIB nacional. O Chile - país com PIB menor que o brasileiro - investe cerca de $2 \%$ do seu PIB na educação terciária. Os países pertencentes à OCDE investem em média 1,5\% do PIB na educação superior. Na análise de alguns países, tais como: Estados Unidos da América (EUA) - investimento de 3,1\% do PIB; Canadá investimento de 2,6\% do PIB; e, Coréia do Sul - investimento de 4\% do PIB, verifica-se a importância dada ao Ensino Superior (CHIARINI; VIEIRA, 2012).

$\mathrm{O}$ orçamento público brasileiro é considerado um dos mais rígidos do mundo. A vinculação orçamentária é o principal fator para amarrar os recursos a uma função ou projeto estatal. A discricionariedade orçamentária brasileira se dá no percentual de $10 \%$ - uma margem pequena para o governante fazer realocações orçamentárias. A vinculação é atrelada à aplicabilidade mínima a uma função do Estado, como, por exemplo, os temas "educação" e "saúde". As alterações orçamentárias requerem medidas via Projetos de Leis (PLs) ou mesmo ECs. Ou seja, tem-se aí um orçamento brasileiro engessado (MACIEL, 2013).

O financiamento público para a educação ainda é insuficiente e, para corrigir as lacunas, o Estado poderá adotar outras formas alternativas de financiamento, tais como: alterações nos impostos existentes, criação de taxas de contribuição, diminuição de renúncias e subsídios fiscais, ampliação da vinculação do imposto para a educação, renda do Pré-Sal, ação do Banco Nacional de Desenvolvimento Econômico e Social (BNDES) e políticas de 
melhoria e eficiência do gasto público. $\mathrm{O}$ atual investimento na educação apenas mantém o cenário existente ou pequenas melhorias na educação nacional.

\subsection{3 Áreas estratégicas do Ensino Superior para o desenvolvimento econômico e o caso do}

\section{Brasil}

O conhecimento é fator primordial para a produção de riqueza de um país. Para Seralgedin (1998), os países precisam fazer uso do conhecimento da melhor maneira possível para lidar com suas lacunas econômicas e sociais. A Organization of American States (OAS) (2005) afirma que a introdução do conhecimento na sociedade pode determinar o desenvolvimento igualitário, reduzir a pobreza e gerar empregos.

Para Schwartzman (2008), nos países desenvolvidos, os investimentos em pesquisa e inovação tecnológica são realizados na maior parte por empresas privadas e organizações militares, mas, na América latina, incluindo o Brasil, este tipo de investimento se dá, em sua maioria, nas universidades. Castro e Souza (2012) também afirmam que as pesquisas de inovação tecnológica estão concentradas nas universidades e instituições de pesquisas públicas. Para fortalecer o investimento em pesquisa e desenvolvimento, o Brasil tem elaborado leis para incentivar tais procedimentos e aumentar a capacidade de desenvolvimento (CASTRO; SOUZA, 2012).

O primeiro ditame no Brasil que visou regulamentar os direitos de propriedade industrial e intelectual foi a de $\mathrm{n}^{\circ}$ 9.279/1996. De acordo Nunes (1967-2007), após a publicação deste, houve um incremento substancial no número de propriedade intelectual das universidades brasileiras, que passaram de 355, no período de 1990 a 1999, para 784, em um período de apenas quatro anos, que compreende entre 2000 e 2004.

No intuito de fortalecer as pesquisas em inovação tecnológica, foi promulgada a Lei da Inovação - Lei $\mathrm{n}^{\circ} 10.973 / 2004$, que dispõe sobre incentivos à pesquisa de inovação tecnológica no país, e, em seu art. $3^{\circ}$, define, in verbis:

Art. $3^{\circ}$. A União, os Estados, o Distrito Federal, os Municípios e as respectivas agências de fomento poderão estimular e apoiar a constituição de alianças estratégicas e o desenvolvimento de projetos de cooperação envolvendo empresas nacionais, ICT e organizações de direito privado sem fins lucrativos voltadas para atividades de pesquisa e desenvolvimento, que objetivem a geração de produtos e processos inovadores.

Parágrafo único. $\mathrm{O}$ apoio previsto neste artigo poderá contemplar as redes e os projetos internacionais de pesquisa tecnológica, bem como ações de empreendedorismo tecnológico e de criação de ambientes de inovação, inclusive incubadoras e parques tecnológicos (BRASIL, 2004). 
O referido ditame visa estimular com fomentos financeiros e fiscais as Instituições Científicas e Tecnológicas, as empresas sem fins lucrativos, o inventor independente e os Fundos de Investimentos. Para Castro e Souza (2012, p. 4), "sua promulgação foi responsável por definir as regras quanto à participação dos criadores da tecnologia nos ganhos econômicos gerados pela proteção de propriedade intelectual."

Ainda de acordo com Castro e Souza (2012), a Lei nº 10973/2004 obriga a instalação de Núcleos de Inovação Tecnológica (NITs) nos Institutos de Ciências e Tecnologia (ICTs) das universidades e define tais ações como política estratégica para o desenvolvimento nacional.

A Lei $n^{\circ} 11.487$, de incentivo à ciência e tecnologia, sancionada em 2007, altera a Lei $\mathrm{n}^{\circ}$ 11.196, de 21 de novembro de 2005, ao ofertar novo incentivo à inovação tecnológica e modificar as regras relativas à amortização acelerada para investimentos vinculados à pesquisa e ao desenvolvimento. Tal ditame apresenta critérios de direito de propriedade intelectual. As empresas recebem isenção fiscal inversamente proporcional ao direito de propriedade, ou seja, quanto menor a isenção fiscal, maior é o direito da empresa sobre a pesquisa. O limite mínimo de isenção é calculado como sendo metade da carga tributária do valor gasto pela empresa no projeto de pesquisa - aproximadamente $17 \%$, e o limite máximo para a isenção fiscal é de duas vezes e meia a carga tributária dos dispêndios realizados pela empresa no projeto de pesquisa - cerca de $85 \%$ (BRASIL, 2007).

O Instituto Nacional da Propriedade Industrial (INPI) é o responsável no Brasil para a concessão de patentes. No período de 2003 a 2013, foram concedidas 34.189 patentes. Conforme o relatório mais recente da Organização Mundial de Propriedade Intelectual (OMPI), de 2012, o país encontra-se em desvantagem em relação aos países de referência sobre inovação tecnológica. Neste sentido, tem-se: EUA, em primeiro lugar, com 2.200.000; Japão, com 1.600.000; China, com 875.000; Coréia do Sul, com 738.000; Alemanha, com 549.000; França, com 490.000; e, Reino Unido, com 459.000. O Brasil ocupa a $19^{a}$ posição. O tempo médio de resposta do INPI passou de seis vírgula oitenta e um anos, em 2003, para 10,8 anos, em 2013 - quase dobrando o tempo de espera, o que desestimula a produção de patentes no país (CNI, 2014).

Dados da Universidade Estadual de Campinas (UNICAMP) (2012) revelam que os maiores impetrantes de patentes no Brasil, no período de 2001 a 2010, se dá como se segue: Petrobras, com 415 patentes; UNICAMP, com 394 patentes; Universidade de São Paulo (USP), com 235 patentes; Fundação de Amparo à Pesquisa do Estado de São Paulo 
(FAPESP), com 143 patentes; e, Universidade Federal de Minas Gerais (UFMG), com 139 patentes. Tem-se, então, que $27 \%$ as patentes brasileiras foram requeridas por universidades.

\begin{abstract}
A economia do conhecimento baseia-se no desenvolvimento para os mercados mundiais de produtos sofisticados, que fazem uso de conhecimento intensivo, e na crescente concorrência entre países e corporações multinacionais, com base em sua competência científica e tecnológica (SCHWARTZMAN, 2008, p. 19).
\end{abstract}

O governo brasileiro é o responsável por $60,2 \%$ dos recursos investidos em pesquisa e desenvolvimento no país, enquanto 39,8\% dos recursos são financiados pela iniciativa privada. Nos países desenvolvidos, este tipo de patrocínio se dá de modo inverso à situação brasileira, ou seja, o investimento privado é cerca de $64 \%$, e o investimento público é de $36 \%$ (CASTRO; SOUZA 2012).

A Pesquisa Industrial de Inovação Tecnológica (PINTEC) tem como objetivo o aumento da eficiência econômica, do desenvolvimento e da difusão de tecnologias. Esta sugere áreas do conhecimento que são importantes para o desenvolvimento nacional. Os eixos de atuação são definidos em áreas de opções estratégicas e atividades portadoras de futuro (CHIARINI; VIEIRA, 2012).

Quadro 2 - Áreas estratégicas para o desenvolvimento econômico.

\begin{tabular}{|l|c|c|}
\hline Áreas do Conhecimento - CAPES & Setores Estratégicos - PINTEC & $\begin{array}{c}\text { Estratégicas/Portadoras de } \\
\text { Futuro }\end{array}$ \\
\hline Ciências Exatas e da Terra & Software & Estratégica \\
\hline \multirow{2}{*}{ Engenharia } & Semicondutores & Estratégica \\
\cline { 2 - 3 } & Bens de capital & Estratégica \\
\hline Ciências da Saúde & Fármacos & Estratégica \\
\hline Ciências Agrárias & Biomassa & Atividades de Futuro \\
\hline \multirow{2}{*}{ Ciências Biológicas } & - & Não estratégica \\
\hline Ciências Sociais Aplicadas & - & Não estratégica \\
\hline Humanas & - & Não estratégica \\
\hline Linguística, Letras e Artes & - & Não estratégica \\
\hline Multidisciplinar & Biotecnologia & Atividades de Futuro \\
\hline
\end{tabular}

Fonte: Adaptado de Chiarini e Vieira (2012). 
A fim de compreender a situação brasileira, faz-se importante comparar o percentual de matrículas com as áreas identificadas pela PINTEC como estratégicas para o desenvolvimento econômico nacional.

Tabela 6 - Matrículas no Ensino Superior por área.

\begin{tabular}{lccccc}
\hline País & Saúde (\%) & $\begin{array}{c}\text { Ciências } \\
\text { Biológicas, Físicas } \\
\text { e Agrárias (\%) }\end{array}$ & $\begin{array}{c}\text { Matemática e } \\
\text { Ciência da } \\
\text { Computação (\%) }\end{array}$ & $\begin{array}{c}\text { Ciências } \\
\text { Humanas, Sociais, } \\
\text { Letras, Artes e } \\
\text { Educação (\%) }\end{array}$ & $\begin{array}{c}\text { Engenharia } \\
(\%)\end{array}$ \\
\hline OCDE & 13,5 & 7,0 & 4,8 & 62,3 & 12,2 \\
Brasil & 15,6 & 4,9 & 2,7 & 66,4 & 4,6 \\
Coréia & 9,2 & 6,2 & 4,9 & 56,4 & 23,2 \\
\hline
\end{tabular}

Fonte: Chiarini e Vieira (2012).

Diante do exposto, é possível perceber que o Brasil mostra-se aquém dos países comparados em percentual de matrículas para a formação de pessoas nas citadas áreas estratégicas de desenvolvimento, e sua maior deficiência se dá na Engenharia, com diferença de 7,6\% em relação a média dos países que compõem a OCDE.

Chiarini e Vieira (2012, p. 121) asseguram que "a observação da natureza dos investimentos em educação superior, bem como dos estudantes matriculados, segundo a área de conhecimento, é importante para que se possa caracterizar a formação de mão de obra qualificada no país." Ainda segundo aqueles autores, uma das causas possíveis para a concentração de formação nas áreas humanas e sociais no Brasil é devido à forte presença do setor público na oferta de mão de obra.

Neste sentido, Nunes (1967-2007, p. 105) afirma que a administração pública carece na análise da "educação superior como um dos mais importantes e cruciais temas operacionais e estratégicos da nação e do Estado brasileiro."

Sem dúvida, existe uma diferença gritante entre a população adulta brasileira portadora de diploma superior quando comparada com a população analisada pela OCDE, apresentando-se conforme a Tabela 7, a seguir. 
Tabela 7 - Percentual da população com nível superior.

\begin{tabular}{lcc}
\hline $\begin{array}{c}\text { Percentual da população que alcançou nível de escolaridade do } \\
\text { Ensino Superior }\end{array}$ & Brasil - 2011 & OCDE - 2011 \\
\hline População entre 25 e 64 anos de idade & $12 \%$ & $32 \%$ \\
População entre 30 e 34 anos de idade & $12 \%$ & $39 \%$ \\
População entre 25 e 34 anos de idade & $13 \%$ & $39 \%$ \\
População entre 55 e 64 anos de idade & $9,0 \%$ & $24 \%$ \\
\hline
\end{tabular}

Fonte: OCDE (2013).

A discrepância evidenciada pode ser uma das causas para a explicação das diferenças de qualidade de vida, capacidade técnica e desenvolvimento humano identificadas. A renda domiciliar dos matriculados no ensino do terceiro grau é superior aos estudantes de nível médio, o que indica que se não houver fomento de manutenção destes, dificilmente o Brasil aumentará a taxa de escolaridade (NUNES, 1967-2007).

\footnotetext{
Pouco se faz para lidar com desafios fundamentais inerentes à desejável ascensão do país, e de sua educação superior no contexto mundial. Solenemente ignora-se, por exemplo, o desafio de se aumentar a qualidade do setor público, de forma que se tenham universidades de classe mundial (NUNES, 1967-2007, p. 115).
}

De acordo o mais recente trabalho da OCDE, Education at a Glance 2013 OECD Indicators, o Brasil vem demonstrando um leve crescimento na escolarização, mas ainda abaixo da média dos países analisados por aquela Organização. Neste sentido, tem-se o dado nacional de 2011, que apresentou apenas $43 \%$ da população, entre 25 a 64 anos de idade, detentora do Ensino Médio, enquanto nos países analisados pela OCDE, tem-se o percentual de $75 \%$.

No presente estudo se dá ao nível terciário da educação e, para esta mesma população, somente $12 \%$ concluíram o Ensino Superior, e para a OCDE, o percentual desta classe é de $32 \%$.

Ainda segundo a OCDE (2013), o Ensino Superior no Brasil, em termos de empregabilidade, apresenta uma pequena vantagem quando comparado com a média dos países que compõem a OCDE. Para o Brasil, a taxa é de $85 \%$, enquanto na OCDE, é de $83 \%$. Possuir Ensino Superior no Brasil aumenta a probabilidade de estar empregado mais do que em outros países. Além disso, o salário médio no Brasil para quem tem nível superior é $157 \%$ maior quando comparado com pessoas que possuem apenas o Ensino Médio. A diferença salarial também se dá na OCDE, mas em escala menor, sendo o contraste de $57 \%$ sobre a mesma população. 
O conhecimento e sua aplicação tornaram-se o insumo básico para o progresso dos povos. À divisão entre possuidores ou não de recursos naturais, de capital físico, segue-se a separação entre as nações detentoras ou não de conhecimentos e tecnologias. $\mathrm{Na}$ atualidade, o conhecimento aplicado divide os povos entre ricos e pobres. Como corolário dessa, resulta o princípio de que o desenvolvimento de um povo depende da geração e/ou aquisição de conhecimentos, onde eles estiverem (CONTINI; SÉCHET, 2011, p, 31).

O termo "inovação" é entendido como a criação ou melhoramento significativo de um produto, processo ou método que melhora as condições de trabalho ou relações externas. Dutta e Benavente (2011) definem a inovação social como aquela transmitida, aceita e difundida na sociedade ou em parte desta, sem interesse de lucro, até a prática inovativa se tornar rotina.

A pesquisa e inovação no Brasil vêm enfrentando mudanças significativas com ações regulatórias que fortalecem tais áreas, mas ainda enfrentam dificuldades históricas entre as empresas e universidades que trabalham para a promoção da inovação brasileira, devido à limitação de financiamento. Entre as ações de mudanças, destacam-se as Leis nº 10.973/2004, 11.196/2005 e o REUNI (NEVES; NEVES, 2011).

A finalidade do REUNI foi de expandir a oferta de vagas nas IFES com a criação de 10 novas universidades federais e ampliação dos campi universitários. Entre 2006 e 2010, foram criados 1.035 novos cursos de graduação presencial, além de ofertarem 77.279 novas vagas nas referidas Instituições (ANDIFES, 2010).

Existe uma severa crítica sobre o REUNI, uma vez que se preocupou apenas com a expansão de infraestrutura física e a criação de vagas nas IFES e, no que tange à pesquisa e inovação, "delega a cada universidade a estipular medidas concretas nesse campo. Seu impacto é portanto, confuso, difuso e aleatório" (NEVES; NEVES, 2011, p. 494).

De fato, as universidades federais absorvem uma parcela importantíssima das pesquisas desenvolvidas no Brasil. Assim, o Estado compreende que as universidades são pontos estratégicos para o desenvolvimento nacional e, portanto, financia as pesquisas alocadas nas IFES por meio de fomentos.

O principal financiador das pesquisas nas universidades federais é o Fundo Nacional de Desenvolvimento Científico e Tecnológico (FNDCT), que engloba o orçamento da Financiadora de Estudos e Projetos (FINEP) e do Conselho Nacional de Desenvolvimento Científico e Tecnológico ( $\mathrm{CNPq}$ ). O financiamento institucional também é feito pelo Ministério da Ciência, Tecnologia e Inovação (MCTI). Mas o CNPq continua sendo o principal financiador de pesquisa no Brasil. Existem também outros fundos setoriais que 
financiam a pesquisa e o desenvolvimento com recursos oriundos dos royalties do petróleo e seus derivados, e sobre o faturamento de empresas de setores específicos (BRASIL, 2010).

O Brasil apresenta poucas interações entre as universidades e as empresas que trabalham com pesquisas e desenvolvimento, o que ocasiona um baixo investimento neste setor, principalmente dos entes privados. A cultura de pesquisa e inovação é pouca disseminada no Brasil. Assim, tem-se a necessidade de seu fortalecimento a partir de iniciativas políticas nas universidades e em outros sistemas de inovação, com o objetivo de formar a dinâmica da economia e educação em que favorecerá o crescimento do país (NEVES; NEVES, 2011).

Romero (2009) afirma que o Brasil não possui uma ótica industrializadora para o longo prazo, o que acabou dando ênfase aos investimentos em ativos fixos em relação aos recursos humanos e, por isso, tornou-se um parque industrial fraco, com baixa qualidade, pouco competitivo e explorador de recursos não renováveis. Para o país avançar é essencial possuir indústrias de valor agregado e, para tanto, é indispensável uma política que fortaleça a educação e a mão de obra com bases marcadas pela tecnologia e conhecimento, o que proporcionará vantagens para a cultura e o desenvolvimento econômico.

As universidades são fundamentais para a formação de capital humano. Tais instituições são responsáveis pela maior parte da produção de pesquisa e desenvolvimento em inovação. O Estado deve promover ações que fortaleçam a demanda por cursos das áreas consideradas estratégicas para o desenvolvimento tecnológico, social e econômico. 


\section{PROGRAMA NACIONAL DE ASSISTÊNCIA ESTUDANTIL}

A formação de capital humano é fundamental para a criação de riquezas e de diminuição de desigualdades sociais existentes em um país, em especial para o Brasil.

A capacitação de pessoas aumenta a aptidão produtiva e inovativa para a geração de novas tecnologias, bens e serviços agregando valores para o desenvolvimento econômico nacional e gerando melhores oportunidades individuais para a ascensão social.

O trabalho em seus capítulos e subcapítulos anteriores demonstra a importância das Universidades públicas e do ensino superior para o caso brasileiro, pois, essas Universidades são as maiores responsáveis pela inovação tecnológica brasileira e que o ensino superior é considerado um dos principais fatores para a ascensão social do povo brasileiro. Vimos que o salário médio para os detentores de ensino terciário é bem superior à média salarial para os detentores somente do nível médio, bem como o nível de empregabilidade dos que possuem o terceiro grau também apresenta melhores índices e o investimento em educação pelo Estado gera externalidades positivas superiores ao aplicado somente na distribuição de renda.

A maior parte de matrículas da educação superior é concentrada na iniciativa privada, e por isso é fundamental dar oportunidade para aqueles que não possuem nenhuma condição de financiar um curso superior na rede de ensino privada e aumentarem a sua probabilidade de ascensão social. Dessa forma, o Estado intervém na educação superior com políticas afirmativas de inclusão social e manutenção desses estudantes por meio do PNAES.

\subsection{Reivindicações por assistência estudantil}

O primeiro registro sobre Assistência Estudantil do Ensino Superior brasileiro, de acordo com M. Araújo (2007), se deu em 1928, com a inauguração da Casa do Estudante Brasileiro em Paris, na França, durante o governo de Washington Luís, visando assegurar uma residência aos estudantes brasileiros que tinham dificuldade de fixar moradia. Outro fato importante foi durante o Governo Vargas, em 1930, com a Casa do Estudante do Brasil, que tinha a finalidade de assistir aos estudantes vulneráveis da época, situada na cidade do Rio de Janeiro.

Foi durante a primeira reforma da educação a nível nacional que houve uma tentativa de regularizar o tema "Assistência Estudantil”, o qual passou a pertencer à Carta Magna de 1934, onde relatava em seu art. 157, in verbis: 
Art 157 - A União, os Estados e o Distrito Federal reservarão uma parte dos seus patrimônios territoriais para a formação dos respectivos fundos de educação.

$\S 1^{\circ}$ - As sobras das dotações orçamentárias acrescidas das doações, percentagens sobre o produto de vendas de terras públicas, taxas especiais e outros recursos financeiros, constituirão, na União, nos Estados e nos Municípios, esses fundos especiais, que serão aplicados exclusivamente em obras educativas, determinadas em lei.

$\S 2^{\circ}$ - Parte dos mesmos fundos se aplicará em auxílios a alunos necessitados, mediante fornecimento gratuito de material escolar, bolsas de estudo, assistência alimentar, dentária e médica, e para vilegiaturas (BRASIL, 1934).

A Constituição de 1946 também corroborava com o argumento de manutenção da Assistência Estudantil, em seu art. 172, in verbis:

Art. 172 - Cada sistema de ensino terá obrigatoriamente serviços de assistência educacional que assegurem aos alunos necessitados condições de eficiência escolar (BRASIL, 1946).

A União Nacional dos Estudantes (UNE), durante o Regime Militar, em 1961, na cidade de Salvador, Bahia, promoveu o documento "Declaração da Bahia", que buscava cursos praticáveis a todos. Neste mesmo ano, foi anunciada a Lei de Diretrizes e Bases da Educação (LDB), que continuava com a preocupação de assegurar as condições de permanência aos estudantes necessitados (FÁVERO, 1995).

O Governo Médici, respaldado na Constituição de 1967, seu art. 168, assegurava, in verbis:

Art. 168 - A educação é direito de todos e será dada no lar e na escola; assegurada a igualdade de oportunidade, deve inspirar-se no princípio da unidade nacional e nos ideais de liberdade e de solidariedade humana.

$\S 1^{\circ}$ - O ensino será ministrado nos diferentes graus pelos Poderes Públicos.

$\S 2^{\circ}$ - Respeitadas as disposições legais, o ensino é livre à Iniciativa particular, a qual merecerá o amparo técnico e financeiro dos Poderes Públicos, inclusive bolsas de estudo.

$\S 3^{\circ}$ - A legislação do ensino adotará os seguintes princípios e normas:

I - o ensino primário somente será ministrado na língua nacional;

II - o ensino dos sete aos quatorze anos è obrigatório para todos e gratuito nos estabelecimentos primários oficiais;

III - o ensino oficial ulterior ao primário será, igualmente, gratuito para quantos, demonstrando efetivo aproveitamento, provarem falta ou insuficiência de recursos. Sempre que possível, o Poder Público substituirá o regime de gratuidade pelo de concessão de bolsas de estudo, exigido o posterior reembolso no caso de ensino de grau superior;

IV - o ensino religioso, de matrícula facultativa, constituirá disciplina dos horários normais das escolas oficiais de grau primário e médio.

$\mathrm{V}$ - o provimento dos cargos iniciais e finais das carreiras do magistério de grau médio e superior será feito, sempre, mediante prova de habilitação, consistindo em concurso público de provas e títulos quando se tratar de ensino oficial; VI - é garantida a liberdade de cátedra (BRASIL, 1967). 
Em 1970, concebeu o Departamento de Assistência Estudantil (DAE), que cuidava do tema para a graduação em nível federal. Neste contexto, em 1972, foi promulgado o Decreto Presidencial $n^{\circ}$ 69.927, que instituiu, em caráter nacional, o Programa "Bolsa de Trabalho", que considerava "imprescindível a integração de estudante brasileiro no processo de desenvolvimento econômico-social do País." O DAE foi dissolvido durante o Governo Fernando Collor, em 1990. Assim, a Assistência Estudantil passou a ser de responsabilidade de cada universidade (CÂMARA DOS DEPUTADOS, 1972; FONAPRACE, 2004).

Àquelas universidades que persistiram em garantir as ações de Assistência Estudantil retiraram recursos da verba para a manutenção de outras atividades, comprometendo assim o custeio de atividades de ensino, pesquisa e extensão (ARAÚJO, 2007, p. 4).

Por inexistência orçamentária específica, o assunto ficou em segundo plano para as Instituições Federais de Ensino Superior (IFES), o que dificultava a manutenção da oferta assistencial.

Diante da preocupação sobre o tema, em 1987, foi criado o Fórum Nacional de PróReitores de Assuntos Comunitários e Estudantis, composto pelos pró-reitores, decanos ou cargos afins, responsáveis pela Assistência Estudantil nas IFES.

Neste sentido, tem-se o que versa a Carta Magna de 1988, em seus arts. 205 e 206, in verbis:

Art. 205. A educação, direito de todos e dever do Estado e da família, será promovida e incentivada com a colaboração da sociedade, visando ao pleno desenvolvimento da pessoa, seu preparo para o exercício da cidadania e sua qualificação para o trabalho.

Art. 206. O ensino será ministrado com base nos seguintes princípios:

I - igualdade de condições para o acesso e permanência na escola;

II - liberdade de aprender, ensinar, pesquisar e divulgar o pensamento, a arte e o saber;

III - pluralismo de idéias e de concepções pedagógicas, e coexistência de instituições públicas e privadas de ensino;

IV - gratuidade do ensino público em estabelecimentos oficiais;

V - valorização dos profissionais da educação escolar, garantidos, na forma da lei, planos de carreira, com ingresso exclusivamente por concurso público de provas e títulos, aos das redes públicas; (Redação dada pela Emenda Constitucional no 53, de 2006)

VI - gestão democrática do ensino público, na forma da lei;

VII - garantia de padrão de qualidade.

VIII - piso salarial profissional nacional para os profissionais da educação escolar pública, nos termos de lei federal. (Incluído pela Emenda Constitucional $\mathrm{n}^{\circ} 53$, de 2006)

Parágrafo único. A lei disporá sobre as categorias de trabalhadores considerados profissionais da educação básica e sobre a fixação de prazo para a elaboração ou 
adequação de seus planos de carreira, no âmbito da União, dos Estados, do Distrito Federal e dos Municípios. (Incluído pela Emenda Constitucional $n^{\circ} 53$, de 2006) (BRASIL, 1988).

Em 1996, foi promulgada a Lei ${ }^{\circ} 9.394$, a nova LDB, que logo no seu art. $3^{\circ}$ aponta:

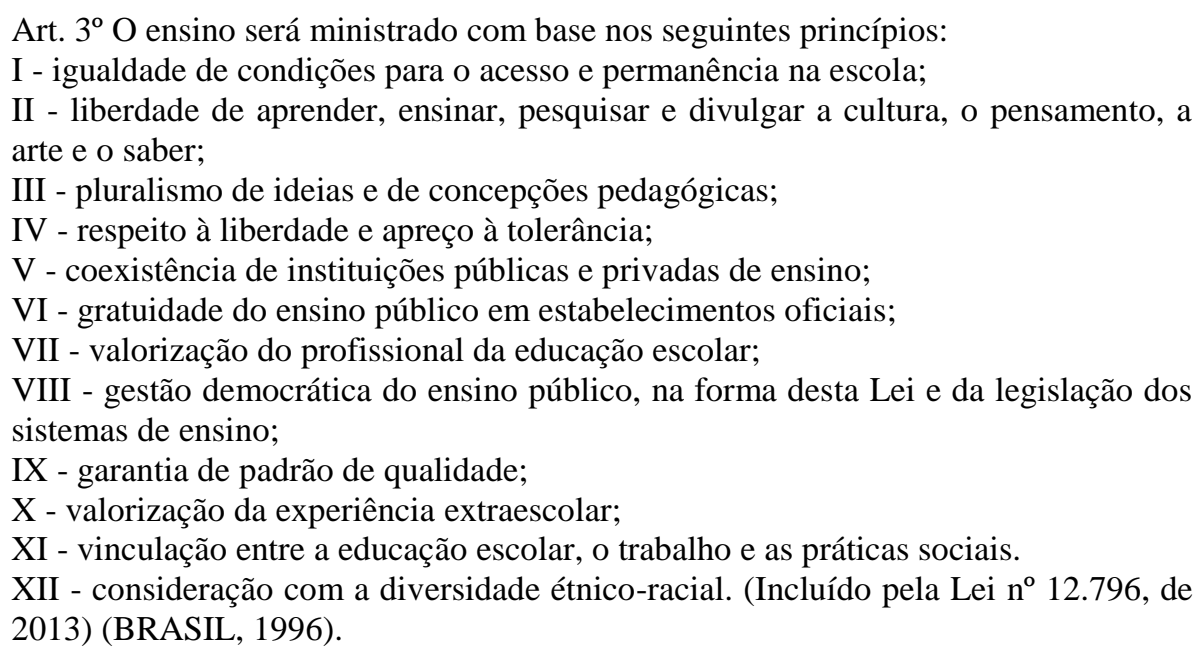

O Fórum Nacional de Pró-Reitores de Assuntos Comunitários e Estudantis (FONAPRACE) realizou duas pesquisas - em 1997 e 2004 - que traçaram o perfil socioeconômico dos estudantes de graduação das IFES. Neste sentido, foi possível apresentar a proposta de um programa de Assistência Estudantil nacional à Associação Nacional dos Dirigentes das Instituições Federais de Ensino Superior (ANDIFES). Consequentemente, o Ministério da Educação (MEC) aprovou a Portaria Normativa $n^{\circ} 39 / 2007$, que originou o Programa Nacional de Assistência Estudantil (PNAES) como uma política pública através do Decreto Presidencial n $7.234 / 2010$.

\subsection{Programa Nacional de Assistência Estudantil: o fortalecimento da assistência estudantil}

Para Cislaghi e da Silva (2011), o PNAES foi concebido no rastro do Programa de Reestruturação e Expansão das Universidades Federais (REUNI), em 2007, por meio da Portaria Normativa $n^{\circ} 39$, do MEC, transformada no Decreto Presidencial $n^{\circ} 7.234 / 2010$.

O PNAES é executado no âmbito do MEC, sendo de responsabilidade das IFES, que deverão "definir os critérios e a metodologia de seleção dos alunos de graduação a serem beneficiados", uma vez que estas conhecem mais as necessidades locais e os tipos de benefícios ali melhor alocados, considerando que o referido Programa "tem como finalidade 
ampliar as condições de permanência dos jovens na educação superior pública federal" dos estudantes regularmente matriculados nos cursos de graduação presencial (BRASIL, 2010).

Ainda de acordo com o referido Decreto:

Art. $2^{\circ}$ São objetivos do PNAES:

I - democratizar as condições de permanência dos jovens na educação superior pública federal;

II - minimizar os efeitos das desigualdades sociais e regionais na permanência e conclusão da educação superior;

III - reduzir as taxas de retenção e evasão; e

IV - contribuir para a promoção da inclusão social pela educação (BRASIL, 2010).

Neste sentido, Alves (2002, p. 29) destaca:

Há a necessidade da democratização do Ensino Superior, democratização essa voltada não apenas a ações de acesso à universidade pública gratuita, como também com mecanismos para a permanência, reduzindo os efeitos das desigualdades apresentadas por um conjunto de estudantes, provenientes de segmentos sociais cada vez mais pauperizados e que apresentam dificuldades concretas de prosseguirem sua vida acadêmica com sucesso.

Os recursos destinados ao Programa poderão ser aplicados nas seguintes ações, conforme o $\S 1^{\circ}$, art. $3^{\circ}$ do Decreto supramencionado:

Art. $3^{\circ} \mathrm{O}$ PNAES deverá ser implementado de forma articulada com as atividades de ensino, pesquisa e extensão, visando o atendimento de estudantes regularmente matriculados em cursos de graduação presencial das instituições federais de ensino superior.

$\S 1^{\circ}$ As ações de assistência estudantil do PNAES deverão ser desenvolvidas nas seguintes áreas:

I - moradia estudantil;

II - alimentação;

III - transporte;

IV - atenção à saúde;

V - inclusão digital;

VI - cultura;

VII - esporte;

VIII - creche;

IX - apoio pedagógico; e

$\mathrm{X}$ - acesso, participação e aprendizagem de estudantes com deficiência, transtornos globais do desenvolvimento e altas habilidades e superdotação (BRASIL, 2010).

O FONAPRACE (2004) define que a democratização no Ensino Superior não é apenas o aumento quantitativo de vagas. Estas são importantes, mas não são suficientes para que o estudante permaneça na universidade. A Assistência Estudantil deve ser complementada por meio das ações descritas pelo art. $3^{\circ}$ do Decreto Presidencial n ${ }^{\circ} 7.234 / 2010$. 
Discorrer sobre a questão da Assistência Estudantil vai além da transferência de renda, alimentação ou moradia. "A assistência ao estudante deve ser ampliada de forma a democratizar o acesso e garantir uma universidade que, de fato, seja pública, gratuita e comprometida com a permanência de qualidade na educação superior" (ESTRADA; RADAELLI, 2014, p. 6).

Para Silva (2007), a transferência de renda é entendida como uma transferência monetária direta efetuada a indivíduos ou a famílias. O pressuposto central é de que articular uma transferência de renda com políticas e programas estruturantes, principalmente no campo da educação, saúde e trabalho, direcionadas às famílias pobres, pode interromper o ciclo vicioso da pobreza do presente e a sua reprodução no futuro. Além disso, possibilita a construção de uma política de enfrentamento à pobreza e à desigualdade social.

Os benefícios do PNAES diferem dos benefícios acadêmicos e meritórios, por características eminentemente sociais (CISLAGHI; SILVA, 2011).

O Decreto Presidencial $n^{\circ} 7.234 / 2010$ insere ainda que deverão ser atendidos prioritariamente os estudantes oriundos da rede pública de ensino e de famílias cuja renda per capita seja inferior a um salário-mínimo e meio, no intuito de democratizar o Ensino Superior federal.

Para tanto, objetiva-se proporcionar oportunidades iguais entre todos os estudantes e assegurar que aqueles que se encontram em vulnerabilidades econômicas não possam ser prejudicados nos seus desempenhos acadêmicos e permaneçam nas IFES para a conclusão dos cursos, por meio de medidas que buscam combater situações de repetência e evasão. As ações de Assistência Estudantil devem considerar a necessidade de viabilizar a igualdade de oportunidades, contribuir para a melhoria do desempenho acadêmico e agir, preventivamente, nas situações de retenção e evasão decorrentes da insuficiência de condições financeiras dos estudantes de baixa renda.

\footnotetext{
A Assistência Estudantil precisa desenvolver ações que atendam os estudantes em suas necessidades enquanto sujeitos em formação. Assim sendo, chega-se à compreensão de que deve estar integrada ao desenvolvimento social e ao exercício pleno da cidadania.... Isso posto, podemos afirmar que, se o PNAES é uma política importante quanto à ampliação da possibilidade e geração de condições de permanência na educação superior, pois, uma vez possibilitado o acesso, a permanência dos estudantes se torna fundamental a fim de que o chamado processo de democratização seja considerado efetivo (ESTRADA; RADAELLI, 2014, p. 8).
} 
A efetivação do PNAES como programa e o gradativo aumento dos recursos financeiros têm contribuído fortemente para o reposicionamento da Assistência Estudantil na estrutura organizacional das universidades federais.

Os benefícios que podem ser concedidos pelo PNAES são aqueles listados no art. $3^{\circ}, \S$ $1^{\circ}$, do Decreto Presidencial $n^{\circ} 7.234 / 2010$, e ainda de acordo com o $\S 2^{\circ}$ do referido artigo, in verbis:

Art. $3^{\circ}[\ldots]$.

$\S 2^{\circ}$ Caberá à instituição federal de ensino superior definir os critérios e a metodologia de seleção dos alunos de graduação a serem beneficiados (BRASIL, 2010).

O PNAES, por entender que as IFES conhecem as suas necessidades específicas, permite que estas levantem as suas necessidades particulares e tracem estratégias para supressão desses pontos. Neste sentido, o Programa possui características discricionárias, permitindo que o gestor do programa possa fazer escolhas dos benefícios, da quantidade de benefícios e dos valores dos benefícios, de modo que possa aplicar os recursos da melhor maneira possível em favor da comunidade que atende aos critérios ali estabelecidos. Assim, cada IFES poderá ter o seu plano com programas e benefícios que melhor atendam a sua realidade.

O PNAES é a garantia de recursos orçamentários investidos diretamente nas IFES para assegurar os programas da Assistência Estudantil, mas tal situação se torna preocupante, pois o mesmo é sustentado por um Decreto Presidencial, tornando-se política de governo, podendo ser descartado a qualquer momento, sendo que o ideal é a transformação do Decreto em Lei, para que o mesmo seja uma política de Estado.

\subsection{Perfil socioeconômico dos estudantes das Instituições Federais de Ensino Superior}

Em 2010, o FONAPRACE deu início à outra pesquisa sobre o perfil socioeconômico dos estudantes das IFES, concluída em 2011, com destaque para o que se segue na Tabela 8:

Tabela 8 - Percentual de estudantes nas Instituições Federais de Ensino Superior por classe econômica.

\begin{tabular}{cccc}
\hline Classe Econômica & Pesquisa 1996/97 (\%) & Pesquisa 2003/04 (\%) & Pesquisa 2010 (\%) \\
\hline A & 12,6 & 15,6 & 15,3 \\
B & 43,1 & 41,5 & 41,1 \\
C & 30,5 & 30,9 & 33,6 \\
D & 10,5 & 11,1 & 9,6 \\
E & 3,3 & 0,8 & 0,5 \\
C + D + E & 44,3 & 42,8 & 43,7 \\
\hline
\end{tabular}

Fonte: FONAPRACE (2011). 
De acordo com a pesquisa do perfil socioeconômico e cultural dos estudantes de graduação das universidades federais, o FONAPRACE considerou que os estudantes que estão nas classes econômicas "C", "D" e "E" estão aptos a receberem benefícios da Assistência Estudantil. A pesquisa contradiz o mito de que somente pessoas ricas ingressam nas universidades públicas. Neste sentido, é possível observar que 43,7\% dos estudantes encontram-se no perfil atendido pela Assistência Estudantil, e se consideramos a classe B2 da tabela 9, o percentual é de 67,16\%. Nota-se ainda a disparidade de acesso as IFES, quando se considera apenas a classe "E", com 0,5\% do preenchimento das vagas (FONAPRACE, 2011, p. 21).

Para classificar as classes sociais, o FONAPRACE utilizou a metodologia da Associação Brasileira das Empresas de Pesquisas (ABEP) (2010), conforme exposto na Tabela 9, a seguir.

Tabela 9 - Renda média familiar por classe econômica.

\begin{tabular}{ccc}
\hline Classe & Pontos & Renda Média Familiar em 2009 (R\$) \\
\hline A1 & 42 a 46 & $11.480,00$ \\
A2 & 35 a 41 & $8.295,00$ \\
B1 & 29 a 34 & $4.754,00$ \\
B2 & 23 a 28 & $2.656,00$ \\
C1 & 18 a 22 & $1.459,00$ \\
C2 & 14 a 17 & 962,00 \\
D & 08 a 13 & 680,00 \\
E & 00 a 07 & 415,00 \\
\hline
\end{tabular}

Fonte: FONAPRACE (2011).

A classificação da ABEP define a classe econômica brasileira, abstendo-se da medição da classe social. O critério de classificação tem a finalidade de segmentar as classes econômicas pelo poder aquisitivo fazendo uso de sistemas de pontos. Para o cálculo do sistema de pontos, verifica-se o quantitativo de itens no domicilio, quais sejam: televisores, automóveis, empregados mensalistas e outros, atribuindo-se pontos por item e quantidade encontrada, além de verificar o grau de instrução do chefe de família com a atribuição de pontos conforme a sua escolaridade. A referida Associação separa os níveis econômicos por escala de pontos identificando, assim, a renda média e o poder aquisitivo de cada classe (ABEP, 2010).

Para a ABEP (2010), enquadram-se na classe "E" aqueles que recebem renda familiar de até $\mathrm{R} \$ 415,00$ (quatrocentos e quinze reais), sendo aqueles que mais necessitam da 
Assistência Estudantil e, conforme a renda familiar vai aumentando, a necessidade de ser amparado é inversamente proporcional. A renda da classe "A" é no mínimo 27 vezes maior que a renda média auferida pela população da classe "E".

A Secretaria de Educação Superior (SESu) instaurou, em 1995, a Comissão Especial de Estudos sobre a Evasão nas Universidades Públicas Brasileiras, que constatou que 40\% dos ingressantes saiam das universidades antes da conclusão dos cursos, o que onera os gastos públicos per capita com educação e fortalece a ideia de que o acesso ao Ensino Superior deve ser vinculado à manutenção dos estudantes nas IFES (BRASIL, 2014). O REUNI estabelece que a taxa de conclusão a ser alcançada é de $90 \%$ nos cursos de graduação presencial - o que é extremamente alta, uma vez que os países analisados pela Organização para a Cooperação e Desenvolvimento Econômico (OCDE), em 2007, apresentaram uma taxa de conclusão de 70\%. (OCDE, 2008, p 76).

Ainda de acordo com a pesquisa do FONAPRACE (2011), o trancamento de matrículas nas IFES é de 12,4\%, distribuído conforme o expresso na Tabela 10, a seguir.

Tabela 10 - Trancamento de matrículas.

\begin{tabular}{|c|c|c|c|c|c|c|c|c|}
\hline \multirow{9}{*}{ 苞 } & Classe & $\begin{array}{l}\text { Não } \\
(\%)\end{array}$ & $\begin{array}{c}\text { Sim, por } \\
\text { insatisfação } \\
\text { com o curso } \\
(\%)\end{array}$ & $\begin{array}{c}\text { Sim, por } \\
\text { impedimento } \\
\text { de saúde }(\%)\end{array}$ & $\begin{array}{c}\text { Sim, por } \\
\text { impedimento } \\
\text { financeiro } \\
(\%)\end{array}$ & $\begin{array}{c}\text { Sim, por } \\
\text { licença- } \\
\text { maternidade } \\
(\%)\end{array}$ & $\begin{array}{c}\text { Sim, } \\
\text { por } \\
\text { outro } \\
\text { motivo } \\
(\%)\end{array}$ & $\begin{array}{c}\text { Geral } \\
(\%)\end{array}$ \\
\hline & A1 & 2,38 & 2,03 & 1,27 & 0 & 0 & 2,92 & 2,35 \\
\hline & A2 & 13,3 & 13,16 & 4,52 & 0,66 & 0 & 12,5 & 12,9 \\
\hline & B1 & 17,9 & 13,72 & 12,61 & 4,79 & 11,35 & 19,23 & 17,58 \\
\hline & B2 & 22,9 & 22,59 & 27,93 & 27,03 & 20,56 & 29,27 & 23,49 \\
\hline & $\mathrm{C} 1$ & 19,4 & 19,07 & 32,02 & 24,4 & 25,13 & 18,34 & 19,59 \\
\hline & $\mathrm{C} 2$ & 14 & 12,7 & 13,77 & 21,49 & 23,96 & 11,9 & 14,01 \\
\hline & $\mathrm{D}$ & 9,63 & 12,64 & 7,89 & 20,22 & 18,99 & 5,77 & 9,6 \\
\hline & $\mathrm{E}$ & 0,41 & 4,1 & 0 & 1,39 & 0 & 0,08 & 0,47 \\
\hline
\end{tabular}

Fonte: FONAPRACE (2011).

Diante do universo de trancamento de matrículas, a disposição encontrada é de que $16 \%$ dos discentes trancam por insatisfação com o curso escolhido, 15\% por motivos financeiros e $10 \%$ por questão de saúde. O descontentamento pelo curso tem maior relevância nas classes "A" e "B" que somam 51,5\%, e a questão do impedimento financeiro se dá fortemente nas classes "B2", "C" e "D". 


\subsection{Matriz de distribuição orçamentária do Programa Nacional de Assistência Estudantil}

Os valores investidos no PNAES demonstram a preocupação governamental com a manutenção dos estudantes em vulnerabilidade socioeconômica e a descentralização dos recursos para melhor gerenciamento por parte das IFES. Os primeiros aportes orçamentários foram disponibilizados às IFES em 2008, via Portaria Normativa $n^{\circ}$ 39/2007, do MEC, após vários embates do FONAPRACE sobre a necessidade de um programa de apoio a estudantes que necessitam de algum tipo de ajuda para a sua formação acadêmica. O Programa teve uma grande aceitação após os seus dois primeiros anos de implementação e, em 2010, foi decretada como política do Governo Federal mediante o Decreto Presidencial no 7.234/2010. Desde a sua criação, ou seja, de 2008 a 2014, o PNAES repassou às IFES o total de R\$ 2.849.423.633,00 (dois bilhões, oitocentos e quarenta e nove milhões, quatrocentos e vinte e três mil e seiscentos e trinta e três reais), distribuídos conforme expresso no Gráfico 2, a seguir.

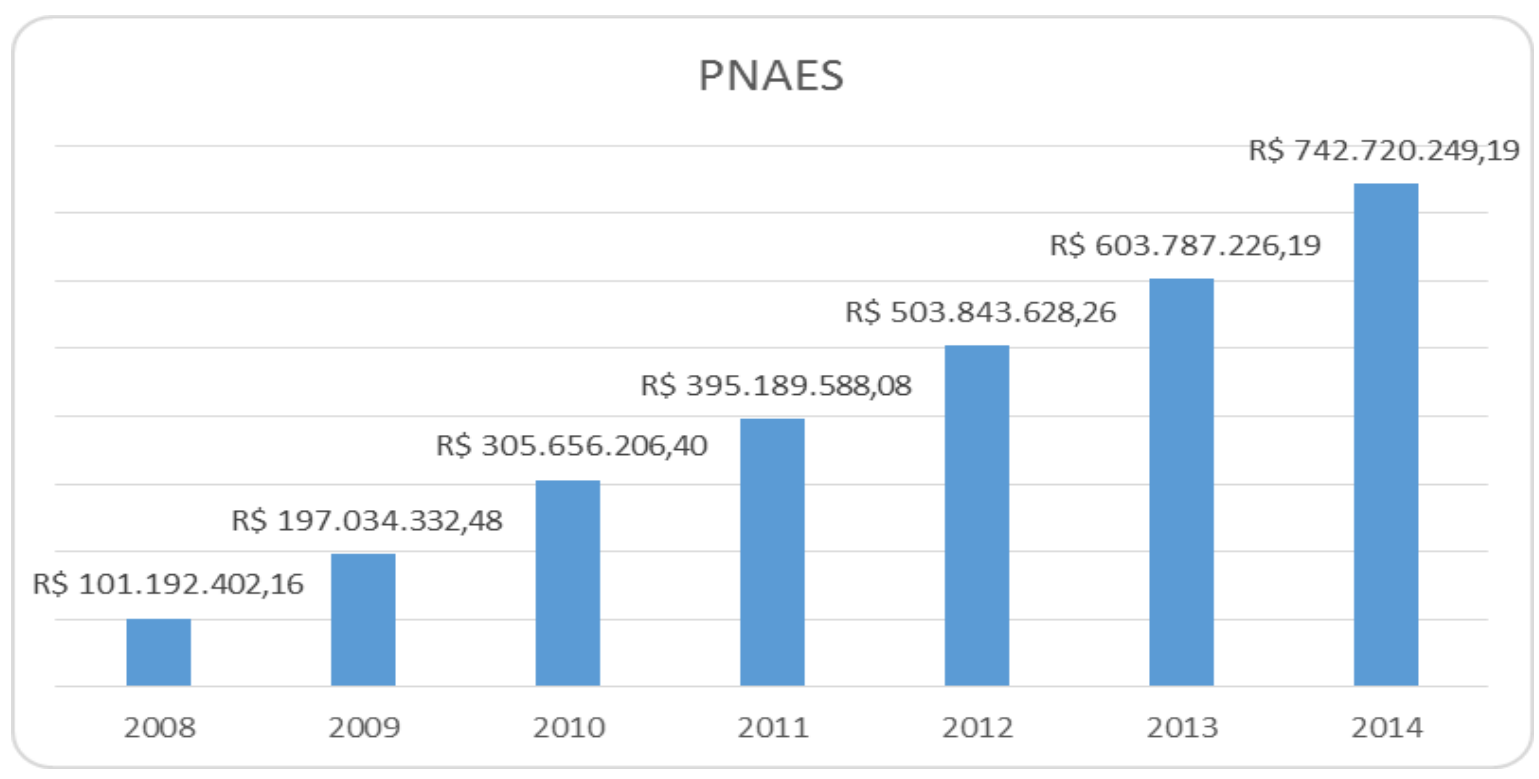

Gráfico 2 - Recursos do Programa Nacional de Assistência Estudantil para as Instituições Federais de Ensino Superior.

Fonte: Adaptado de Brasil (2014).

A matriz de distribuição dos recursos do PNAES é dada da seguinte forma: a universidade que utilizar integralmente o Exame Nacional do Ensino Médio (ENEM) para a seleção dos ingressantes receberão $100 \%$ dos recursos do PNAES, e quem utilizar o referido 
Exame para a seleção de 50\% das vagas, receberá $75 \%$ dos recursos; e as universidades que utilizarem parcialmente o Exame receberão $50 \%$ do valor, e apenas $25 \%$ dos recursos nos demais casos (CISLAGHI; SILVA, 2011).

O PNAES considera "a centralidade da Assistência Estudantil como estratégia de combate às desigualdades sociais e regionais, bem como sua importância para a ampliação e a democratização das condições de acesso e permanência dos jovens no ensino superior público federal" (Portaria Normativa MEC nº 39/2007). A Assistência Estudantil é estratégica para difundir a educação superior como possibilidade de ascensão social e para buscar a coesão social por meio das promessas da educação. 
Tabela 11 - Distribuição orçamentária do Programa Nacional de Assistência Estudantil por região.

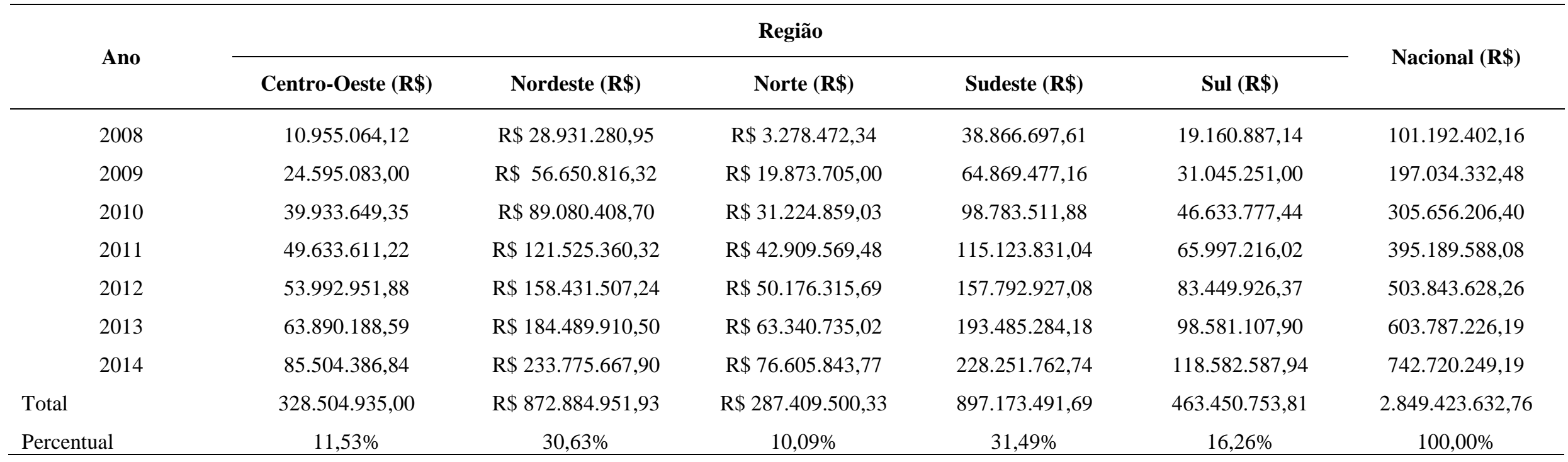

Fonte: Adaptado de Brasil (2014). 
A Tabela 11 apresentada anteriormente demonstra a distribuição orçamentária do PNAES por região brasileira desde a sua concepção. Conforme o exposto é possível observar que a região Sudeste é aquela que mais recebe recurso do PNAES, com 31,49\% do montante distribuído, seguido pelas regiões Nordeste, com 30,63\%; Sul, com 16,26\%; Centro-Oeste, $11,53 \%$; e, Norte, com 10,09\%.

O PNAES é um programa de cunho social e, neste sentido, faz-se importante analisar a sua distribuição de recursos com os dados do Índice de Desenvolvimento Humano Municipal $(\mathrm{IDHM})^{2}$ em prol da diminuição da discrepância social brasileira, tendo em vista que o objetivo primordial é e assegurar a diplomação de estudantes vulneráveis economicamente.

O IDHM das regiões brasileiras está distribuído do maior para o menor: Sul, 0,756; Sudeste, 0,754; Centro-Oeste, 0,753; Norte, 0,684; e, Nordeste, 0,660, sendo que as três primeiras regiões apresentam alto desenvolvimento e as duas últimas apresentam médio desenvolvimento. Quando o referido Índice trata da educação, ou seja, o ÍDHM-Educação ${ }^{3}$, há pouca mudança no ranking, alternando apenas nas duas primeiras posições, passando a configurar do seguinte modo: Sudeste, 0,671; Sul, 0,669; Centro-Oeste, 0,663; Norte, 0,587; e, Nordeste, 0,565; mas é preciso atentar para a classificação dos índices, onde as três primeiras regiões são classificadas como médio desenvolvimento e, as duas últimas, como baixo desenvolvimento (BRASIL, 2014).

O número de benefícios concedidos aos estudantes é crescente. A Tabela 12, a seguir, demonstra o quantitativo de benefícios distribuídos anualmente e também o acumulado ao longo dos anos. Ressalta-se que um estudante pode receber mais de um benefício (auxílio moradia, auxílio financeiro, auxílio alimentação e outros). É possível o surgimento de dúvidas sobre os dados que datam de 2008 pelo motivo do Programa ser objeto de Decreto Presidencial somente em 2010, mas cabe ressaltar que o PNAES teve a sua origem por meio da Portaria Normativa no 39/2007, do MEC.

\footnotetext{
${ }^{2}$ O IDHM ajusta o Índice de Desenvolvimento Humano (IDH) para a realidade dos municípios e reflete as especificidades e desafios regionais no alcance do desenvolvimento humano no Brasil.

3 O IDHM-Educação é medido pela composição de dois subíndices. A escolaridade adulta é medida pelo percentual de pessoas de 18 anos ou mais com Ensino Fundamental completo e o fluxo da população jovem é medido pelo percentual de crianças de 5 a 6 anos na escola, de jovens de 11 a 13 anos frequentando os anos finais do Ensino Fundamental, do percentual de jovens de 15 a 17 com o Ensino Fundamental completo e do percentual de jovens de 18 a 20 com Ensino Médio completo (PNUD, 2013).
} 
Tabela 12 - Benefícios distribuídos no Programa Nacional de Assistência Estudantil.

\begin{tabular}{cccccccc}
\hline \multirow{2}{*}{ Região } & \multicolumn{7}{c}{ Ano } \\
\cline { 2 - 7 } & $\mathbf{2 0 0 8}$ & $\mathbf{2 0 0 9}$ & $\mathbf{2 0 1 0}$ & $\mathbf{2 0 1 1}$ & $\mathbf{2 0 1 2}$ & $\mathbf{2 0 1 3}$ & Total \\
\hline Centro-Oeste & 24.911 & 61819 & 66468 & 36366 & 38457 & 134699 & 362.720 \\
Nordeste & 52.508 & 70642 & 114075 & 61423 & 68784 & 158037 & 525.469 \\
Norte & 17.438 & 18009 & 76470 & 28278 & 31631 & 164909 & 336.735 \\
Sudeste & 66.951 & 147544 & 292281 & 834977 & 833033 & 554833 & 2.729 .619 \\
Sul & 36.418 & 110486 & 184966 & 117044 & 124875 & 353630 & 927.419 \\
Nacional & $\mathbf{1 9 8 . 2 2 6}$ & $\mathbf{4 0 8 . 5 0 0}$ & $\mathbf{7 3 4 . 2 6 0}$ & $\mathbf{1 . 0 7 8 . 0 8 8}$ & $\mathbf{1 . 0 9 6 . 7 8 0}$ & $\mathbf{1 . 3 6 6 . 1 0 8}$ & $\mathbf{4 . 8 8 1 . 9 6 2}$ \\
\hline
\end{tabular}

Fonte: Adaptado de Brasil (2014).

Os dados expressos na Tabela 12 revelam que as regiões que possuem os melhores índices do IDHM e IDHM-Educação, ou seja, as regiões Sudeste e Sul, são a que apresentam os maiores números de benefícios distribuídos aos estudantes.

O PNAES deve fornecer garantias mínimas de manutenção destes para que a qualidade do aprendizado não seja prejudicada. E de acordo com Estrada e Radelli (2014, p. 8), “os dados refletem a necessidade de implementação de uma política baseada em uma profunda discussão, com novas perspectivas na ampliação de recursos e programas que permitam uma efetiva inserção social”. 


\section{MÉTODOS E TÉCNICAS DE PESQUISA}

\subsection{Tipo e descrição da pesquisa}

“O método é o conjunto das atividades sistemáticas e racionais que, com maior segurança e economia, permite alcançar o objetivo - conhecimentos válidos e verdadeiros -, traçando o caminho a ser seguido, detectando erros e auxiliando as decisões do cientista" (MARCONI; LAKATOS, 2003, p. 83).

A metodologia adotada no presente estudo foi a que configura o estudo de caso, pois, de acordo com Yin (1989, p. 23), “o estudo de caso é uma inquirição empírica que investiga um fenômeno contemporâneo dentro de um contexto da vida real, quando a fronteira entre o fenômeno e o contexto não é claramente evidente e onde múltiplas fontes de evidência são utilizadas." E ainda, segundo aquele autor, tal método é utilizado em situações onde os comportamentos relevantes não podem ser manipulados, mas onde é possível se fazer observações diretas.

A pesquisa empregada foi do tipo descritiva, uma vez que, segundo Vergara (2000), esta expõe as características de determinada população ou fenômeno, estabelece correlações entre variáveis e define sua natureza.

A abordagem da pesquisa foi de tipo misto, tendo em vista a compreensão das análises qualitativa e quantitativa.

Para Denzin e Lincoln (2000), a abordagem qualitativa compreende estudos nos quais o enfoque é naturalista e interpretativo da realidade, sendo que este tipo de análise envolve materiais empíricos que podem ser utilizados em estudos de casos. De acordo com Flick (2004), a pesquisa qualitativa é indicada para verificar casos reais e com pressupostos temporal e local. Já a pesquisa quantitativa preocupa-se com a medição de dados; é bastante utilizada em pesquisas descritivas, as quais pretendem descobrir e classificar a relação de variáveis com as causas e efeitos dos eventos pesquisados (OLIVEIRA, 1997).

\subsection{Caracterização do lócus da pesquisa}

A pesquisa empreendida nas linhas que se seguem fez-se na Universidade de Brasília (UnB) - Instituição Federal de Ensino Superior (IFES) com sede em Brasília, Distrito Federal, composta por quatro campus, a saber: Darcy Ribeiro, Faculdade UnB Ceilândia (FCE), Faculdade UnB Gama (FGA) e Faculdade UnB Planaltina (FUP). Tem-se ali a oferta 
de cursos de graduação e pós-graduação gratuitos à população. $\mathrm{O}$ setor analisado foi a Diretoria de Desenvolvimento Social do Decanato de Assuntos Comunitários (DDS/DAC) da referida Universidade - responsável pela Assistência Estudantil na instituição.

Conforme o anuário estatístico 2013 da UnB, a Universidade registra o quantitativo de 44.449 alunos regularmente matriculados, assim distribuídos:

Tabela 13 - Número de estudantes regularmente matriculados na Universidade de Brasília.

\begin{tabular}{lc}
\hline \multicolumn{1}{c}{ Alunos Regulares Registrados } & Ano: 2012 \\
\hline Graduação & 36.135 \\
Residência Médica & 311 \\
Especialização & Não Declarado \\
Mestrado & 4.983 \\
Doutorado & 3.020 \\
Total & 44.449 \\
\hline
\end{tabular}

Fonte: UnB (2014a).

No presente estudo, somente se deu a verificação dos discentes matriculados em cursos de graduação, conforme preconiza o art. $3, \S 2^{\circ}$ do Decreto $n^{\circ} 7.234 / 2010$.

\subsection{População e amostra}

Os sujeitos da pesquisa foram os estudantes da graduação que participam de algum dos programas executados pela DDS/DAC/UnB

Os estudantes, para lograrem os benefícios dos programas existentes na DDS/DAC/UnB, devem passar pelo estudo socioeconômico realizado pelo Serviço de Assistência Social e estar de acordo com o Decreto n ${ }^{\circ} 7234 / 2010$, art. $5^{\circ}$, in verbis:

Art. $5^{\circ}$. Serão atendidos no âmbito do PNAES prioritariamente estudantes oriundos da rede pública de educação básica ou com renda familiar per capita de até um salário mínimo e meio, sem prejuízo de demais requisitos fixados pelas instituições federais de ensino superior.

além de outros requisitos fixados pela UnB, quais sejam:

a) Estudantes regularmente matriculados em disciplinas nos cursos presenciais de graduação. 
b) Renda familiar (somatório de todos os rendimentos das pessoas físicas que compõem o núcleo familiar, de eventuais pessoas jurídicas - por exemplo, empresa ou pequenos negócios - e renda de capital ou bens imóveis).

c) Profissão/ocupação e nível de escolaridade do(s) mantenedor(es) ou cônjuge.

d) Grupo familiar (o número de membros declarados no formulário socioeconômico e comprovados mediante documentação).

e) Despesas da família com aluguel ou com financiamento da casa própria.

f) Pessoas diagnosticadas com doenças crônicas ou degenerativas e pessoas com deficiência.

Diante do exposto, os dados da amostra permitiram conhecer o perfil dos estudantes da UnB que são atendidos pelos Programas ali existentes (e empregados) e se tais benefícios contribuíram para a diplomação de grau dos referidos discentes.

\subsection{Procedimentos de coleta dos dados da pesquisa}

A abordagem do trabalho foi de tipo misto, ou seja, fez-se uso de pesquisa qualitativa e quantitativa. E ainda, para a compreensão e complementação dos dados, fez-se uma análise documental, além de pesquisas, nos sistemas de dados da UnB.

Para Marconi e Lakatos (2003), a pesquisa documental restringe-se a documentos escritos ou não. Neste sentido, a presente pesquisa fez uso dos modais supramencionados arquivos públicos, particulares e fontes estatísticas, além de dados e sistemas existentes na UnB.

Diante do exposto, tem-se que os procedimentos de coleta de dados são indispensáveis para a consecução do objeto de pesquisa.

\subsection{Instrumentos de coleta dos dados da pesquisa}

A técnica de coleta de dados utilizada se deu por meio de pesquisa documental.

A análise de documentos fez-se na UnB, a partir da verificação de fichas, relatórios e outros arquivos pertinentes à Assistência Estudantil. Tal análise buscou dados sócios demográficos dos estudantes beneficiados pelos programas existentes na referida Diretoria, quais sejam: sistema de ensino anterior, raça, sexo, estado civil e outros quesitos. Os principais sistemas de banco de dados da UnB utilizados na presente pesquisa foram o 
Sistema de Graduação (SIGRA) - que identifica os cursos e a taxa de trancamento de matriculas dos estudantes - e o Sistema da Assistência Estudantil (SAEWeb) - que trata especificamente da Assistência Estudantil da UnB. E ainda, foram analisados registros estatísticos do Instituto Brasileiro de Geografia e Estatística (IBGE), do Instituto Nacional de Estudos e Pesquisas Educacionais Anísio Teixeira (INEP), do Ministério da Educação (MEC) e da Organização para a Cooperação e Desenvolvimento Econômico (OCDE), tais como: censo da educação superior, dados econômicos, dados do PNAES, comparações internacionais com o Brasil etc. Em caso de necessidade, os documentos analisados poderão ser digitalizados ou fotografados para eventuais consultas futuras. Assim, será possível, então, catalogar os dados e, posteriormente, tratá-los, para que as informações possam enriquecer esta e outras pesquisas.

A pesquisa bibliográfica aqui empreendida se deu por meio de livros, artigos científicos, teses, dissertações e relatórios técnicos. Mesmo tratando-se de fonte secundária, este tipo de pesquisa tem a finalidade de embasar o tema da pesquisa ofertando conceitos e demonstrações de como o tema está sendo tratado. O referencial teórico é o responsável pelo arcabouço que sustentará a pesquisa.

“A pesquisa bibliográfica não é mera repetição do que já foi dito ou escrito sobre certo assunto, mas propicia o exame de um tema sob novo enfoque ou abordagem, chegando a conclusões inovadoras" (MARCONI; LAKATOS, 2003, p. 182).

Para registro e segurança dos dados expostos nas linhas que se seguem, foram utilizados alguns hardwares e softwares, quais sejam: notebook, pendrives, scanner, caixa arquivo e armazenamento em nuvem.

Para a consistência da presente pesquisa, os instrumentos e procedimentos se deram de acordo com a real necessidade desta.

\subsection{Procedimentos de análise dos dados}

"Os dados representam a aplicação lógica dedutiva e indutiva do processo de investigação. A importância dos dados não está em si, mas em proporcionarem respostas às investigações" (MARCONI; LAKATOS, 2003, p. 167).

Segundo Marconi e Lakatos (2003), a análise dos dados em uma pesquisa se dá em

três etapas, a saber: 1) interpretação - a verificação das variáveis independentes e dependentes, a fim de ampliar o conhecimento sobre o tema abordado; 2) explicação - busca 
o esclarecimento das origens das variáveis; e, 3) especificação - exibe as relações entre as variáveis.

Para a interpretação dos dados aqui coletados fez-se uso de funções estatísticas específicas - média, percentuais, tabelas, gráficos e outras - por meio de software de análise estatística. As variáveis analisadas, em suma, esclarecem o objeto estudado, descrevendo o perfil socioeconômico dos estudantes beneficiados pelos Programas de auxílio existentes na DDS/DAC/UnB, além de identificar em que cursos estão matriculados e mensurar o nível de retenção destes da UnB.

\subsection{Síntese metodológica}

Os dados obtidos sobre o tema aqui proposto tiveram sua origem em fontes oficiais do governo brasileiro, da comunidade internacional, do Fórum Nacional de Pró-Reitores de Assuntos Comunitários e Estudantis (FONAPRACE), da Secretaria de Administração Acadêmica da UnB (SAA/UnB) e da DDS/DAC/UnB, sendo possível a confecção de gráficos, quadros e tabelas para análise e avaliação da educação superior brasileira e do PNAES. Assim, foi possível analisar o ensino superior brasileiro, a atual situação da distribuição dos benefícios e dos recursos em nível nacional e o perfil demográfico daqueles que recebem este tipo de benefício na UnB.

Quadro 3-Quadro síntese metodológico (continua).

\begin{tabular}{|c|l|l|l|l|l|}
\hline Etapa & \multicolumn{1}{|c|}{ Objetivos } & Fontes de Dados & $\begin{array}{c}\text { Tipos de Dados } \\
\text { que Serão } \\
\text { Coletados }\end{array}$ & $\begin{array}{c}\text { Técnicas para } \\
\text { Coletar os Dados }\end{array}$ & $\begin{array}{c}\text { Técnica para } \\
\text { Análise dos Dados }\end{array}$ \\
\hline 1 & $\begin{array}{l}\text { Comparar o } \\
\text { investimento em } \\
\text { educação em } \\
\text { relação ao PIB de } \\
\text { modo internacional. }\end{array}$ & $\begin{array}{l}\text { Relatório OCDE, } \\
\text { IBGE, INEP etc. }\end{array}$ & $\begin{array}{l}\text { Volume de recurso } \\
\text { investido na } \\
\text { educação em } \\
\text { relação ao PIB dos } \\
\text { países } \\
\text { selecionados. }\end{array}$ & $\begin{array}{l}\text { Pesquisa } \\
\text { documental e } \\
\text { sistematização de } \\
\text { planilhas. }\end{array}$ & $\begin{array}{l}\text { Análise estatística } \\
\text { de comparação } \\
\text { (tabelas, gráficos, e } \\
\text { outros). }\end{array}$ \\
\hline 2 & $\begin{array}{l}\text { Apresentar } \\
\text { histórico da } \\
\text { Assistência } \\
\text { Estudantil. }\end{array}$ & $\begin{array}{l}\text { Livros, artigos, } \\
\text { sites da internet e } \\
\text { documentos da } \\
\text { UnB. }\end{array}$ & $\begin{array}{l}\text { Histórico e dados } \\
\text { relativos a } \\
\text { Assistência } \\
\text { Estudantil } \\
\text { brasileira no } \\
\text { ensino superior. }\end{array}$ & $\begin{array}{l}\text { Pesquisa } \\
\text { documental e } \\
\text { Bibliográfica. }\end{array}$ & $\begin{array}{l}\text { Análise } \\
\text { hermenêutica } \\
\text { (interpretação } \\
\text { textual). }\end{array}$ \\
\hline
\end{tabular}


Quadro 3 - Quadro síntese metodológico (conclusão).

\begin{tabular}{|c|c|c|c|c|c|}
\hline Etapa & Objetivos & Fontes de Dados & $\begin{array}{l}\text { Tipos de Dados } \\
\text { que Serão } \\
\text { Coletados }\end{array}$ & $\begin{array}{c}\text { Técnicas para } \\
\text { Coletar os Dados }\end{array}$ & $\begin{array}{c}\text { Técnica para } \\
\text { Análise dos Dados }\end{array}$ \\
\hline 3 & $\begin{array}{l}\text { Descrever o perfil } \\
\text { sócio demográfico } \\
\text { dos estudantes } \\
\text { brasileiros } \\
\text { beneficiados pelo } \\
\text { PNAES e } \\
\text { Distribuição } \\
\text { orçamentária. }\end{array}$ & $\begin{array}{l}\text { Relatório Perfil } \\
\text { demográfico } \\
\text { FONAPRACE, e } \\
\text { MEC. }\end{array}$ & $\begin{array}{l}\text { Raça, sexo, classe } \\
\text { econômica, } \\
\text { trancamento de } \\
\text { matrículas, } \\
\text { distribuição } \\
\text { orçamentária. }\end{array}$ & $\begin{array}{l}\text { Pesquisa } \\
\text { documental, } \\
\text { Bibliográfica. }\end{array}$ & $\begin{array}{l}\text { Estatística como } \\
\text { média, somatório, } \\
\text { tabelas e } \\
\text { percentual. }\end{array}$ \\
\hline 4 & $\begin{array}{l}\text { Apresentar o perfil } \\
\text { sócio demográfico } \\
\text { dos estudantes } \\
\text { beneficiados pela } \\
\text { Assistência } \\
\text { Estudantil da UnB. }\end{array}$ & $\begin{array}{l}\text { SIGRA, } \\
\text { SAEWeb, } \\
\text { Documentos da } \\
\text { DDS. }\end{array}$ & $\begin{array}{l}\text { Raça, sexo, curso, } \\
\text { forma de ingresso, } \\
\text { etc. }\end{array}$ & $\begin{array}{l}\text { Pesquisa } \\
\text { documental e } \\
\text { sistematização de } \\
\text { planilhas. }\end{array}$ & $\begin{array}{l}\text { Estatística como } \\
\text { média, somatório, } \\
\text { tabelas e } \\
\text { percentual. }\end{array}$ \\
\hline 5 & $\begin{array}{l}\text { Mensurar os } \\
\text { benefícios ofertados } \\
\text { pela Assistência } \\
\text { Estudantil da UnB. }\end{array}$ & Relatórios DDS. & $\begin{array}{l}\text { Modalidade e } \\
\text { quantidade de } \\
\text { benefícios } \\
\text { ofertados pela } \\
\text { UnB. }\end{array}$ & $\begin{array}{l}\text { Pesquisa } \\
\text { documental e } \\
\text { sistematização de } \\
\text { planilhas. }\end{array}$ & $\begin{array}{l}\text { Estatística como } \\
\text { média, somatório, } \\
\text { tabelas e } \\
\text { percentual. }\end{array}$ \\
\hline 6 & $\begin{array}{l}\text { Mensurar a evasão } \\
\text { de estudantes da } \\
\text { UnB. }\end{array}$ & $\begin{array}{l}\text { SIGRA e } \\
\text { SAEWeb. }\end{array}$ & $\begin{array}{l}\text { Trancamento de } \\
\text { matrículas. }\end{array}$ & $\begin{array}{l}\text { Pesquisa } \\
\text { documental e } \\
\text { sistematização de } \\
\text { planilhas. } \\
\end{array}$ & $\begin{array}{l}\text { Estatística como } \\
\text { média, somatório e } \\
\text { percentual. }\end{array}$ \\
\hline
\end{tabular}

Fonte: Do autor.

A interpretação dos dados permitiu preconizar um viés crítico do que pode ser melhorado e se o objetivo do PNAES - que é de cunho social - está sendo logrado.

Assim, o presente estudo buscou abordar a metodologia analítica descritiva com resenha crítica da situação dos dados extraídos. A ideia e a contribuição do trabalho foram agregar os dados da melhor maneira possível, em uma análise qualitativa e quantitativa, destacando os dados mais relevantes, para que o leitor possa compreender a importância do PNAES na sociedade e economia brasileira. 


\section{O PLANO NACIONAL DE ASSISTÊNCIA ESTUDANTIL NA UNIVERSIDADE DE BRASÍLIA}

\subsection{A assistência estudantil na Universidade de Brasília}

O Decanato de Assuntos Comunitários (DAC), por meio da Diretoria de Desenvolvimento Social (DDS), é o órgão que promove os programas assistenciais da Universidade de Brasília (UnB). A política assistencial da referida Universidade tem como finalidade promover a inclusão social dos estudantes com necessidades econômicas, a fim de que estes possam ter a mesma oportunidade de diplomação e rendimento acadêmicos, minimizando a evasão e o trancamento de matrículas. Para tanto, faz-se necessário entender que a educação de qualidade de nível superior deve ofertar meios democráticos e igualitários para o acesso e apoio à colação de grau dos estudantes, principalmente daqueles que se encontram em condições economicamente desfavoráveis. Neste sentido, tem-se ali uma série de programas e ações que garantem aos estudantes as condições mínimas para a sua formação.

Podem participar dos programas de Assistência Estudantil da UnB os estudantes que possuem renda familiar per capita de até um salário mínimo e meio, não possuem formação acadêmica superior e atendam as condições do Decreto Presidencial $n^{\mathbf{0}} 7.234 / 2010$, que promove o Programa Nacional de Assistência Estudantil (PNAES).

O DAC promove a política de Assistência Estudantil da UnB e sua execução é de responsabilidade da DDS - executora de atividades, programas e serviços, tais como:

- Atividades:

- Análise socioeconômica: é de responsabilidade dos assistentes sociais, que tem como finalidade averiguar se o estudante possui requisitos que darão acesso aos auxílios e bolsas ofertados pela política de assistência a estudantes da UnB. O estudo socioeconômico é válido por quatro semestres.

- Acolhimento individual: a atividade é promovida pela equipe de assistentes sociais da DDS; se dá de forma espontânea, para aqueles estudantes que procuram ou necessitem de algum atendimento do Serviço Social.

- Serviços:

- Transporte intercampi: é gratuito e ofertado a toda comunidade acadêmica, desde que comprove o vínculo com a UnB. O intuito aqui é a integração de todos os campus da UnB, quais sejam: Darcy Ribeiro, Faculdade UnB 
Ceilândia (FCE), Faculdade UnB Gama (FGA) e Faculdade UnB Planaltina (FUP). O serviço é terceirizado.

- Transporte intracampus: se dá nos mesmos moldes do serviço intercampi, com prioridade para o atendimento de estudantes que participam dos programas da DDS. O intracampus é ofertado somente no campus Darcy Ribeiro.

- Programas:

- Programa Auxílio Socioeconômico da UnB (PASeUnB) (antigo Bolsa Permanência): é a concessão financeira aos estudantes que foram identificados pelo Serviço Social com o perfil para o recebimento do auxílio; é concedido mensalmente e tem a finalidade de complementação financeira, a fim de evitar a evasão e o abandono de curso dos discentes por falta de recursos financeiros.

○ Programa Moradia Estudantil da Graduação e Pós-Graduação: a UnB oferece vagas em moradia temporária aos estudantes presenciais da graduação e da pós-graduação stricto sensu. No que tange à pós-graduação, é ofertada apenas no campus Darcy Ribeiro e em vagas de apartamentos próprios da Fundação Universidade de Brasília (FUB). A moradia da graduação encontra-se em todos campi da FUB e é ofertada em auxílio moradia ou imóveis locados pela referida Fundação até a reinauguração da Casa do Estudante Universitário (CEU). A concessão do benefício pode ser estendida até dois semestres além do tempo regular do curso em que o estudante encontra-se matriculado. A prioridade da moradia estudantil é para os estudantes residentes fora do Distrito Federal ou do Distrito Federal de difícil locomoção aos campi e que se encontram em vulnerabilidade socioeconômica.

- Programa Bolsa Alimentação: os estudantes identificados em perfil desfavorável economicamente poderão fazer as refeições (desjejum, almoço e jantar) gratuitamente nas dependências do Restaurante Universitário (RU), no campus Darcy Ribeiro. Durante o ano de 2014, os campi da FCE e FGA foram contemplados com a extensão do RU, beneficiando também os estudantes ali matriculados. É importante salientar que antes da Resolução n ${ }^{\circ}$ 52/2013, DO Conselho de Administração (CAD) da UnB, havia três classificações econômicas para os estudantes da UnB, quais sejam: o grupo III pagava R\$ 2,50 (dois reais e cinquenta centavos) por refeição; o grupo II pagava R $\$ 1,00$ (um real) por refeição; e, o grupo I pagava $\mathrm{R} \$ 0,50$ (cinquenta centavos de 
real) por refeição; após a referida Resolução, todos os estudantes vulneráveis economicamente realizam as refeições gratuitamente no RU, e aqueles que não fazem parte do Programa desembolsam o valor de $\mathrm{R} \$ 2,50$ (dois reais e cinquenta centavos) por refeição.

○ Programa Auxílio Alimentação: é o auxílio financeiro para o campus que não possui em suas instalações um RU. O auxílio é mensal e tem a função de auxiliar na alimentação do grupo atendido pelo referido Programa. O valor do benefício é fixo e não há distinção da concessão de valores pelo grau de vulnerabilidade econômica do estudante. O auxílio é ofertado para o campus FUP, mas já foi ofertado para os campi FCE e FGA, onde não existiam RUs.

- Programa Auxílio Emergencial: atende as situações inesperadas de estudantes regulamente matriculados em cursos presenciais e que não participam dos programas da política de Assistência Estudantil da UnB. Poderá ser concedido até seis vezes ao ano por estudante. A solicitação do referido auxílio deverá ser analisada pelo setor de assistência social e assinado pela direção da DDS e do DAC.

- Programa Vale Livro: para cada semestre é disponibilizado até cinco cupons que permitirão a compras de livros ou material pedagógico da Editora UnB com $50 \%$ de desconto. O benefício é concedido para estudantes da Assistência Estudantil, e os beneficiários podem ser alunos matriculados em cursos de graduação ou pós-graduação.

- Programa de Acesso a Língua Estrangeira: é uma parceria com a UnB Idiomas, que disponibiliza até duas vagas por turma com a isenção da cobrança de matrículas e mensalidades aos estudantes da Assistência Estudantil.

Diante do exposto, é preciso ressaltar que somente os programas dos auxílios socioeconômicos, alimentação, moradia em pecúnia e o auxílio emergencial são financiados pelo PNAES.

Para que o estudante esteja apto em participar dos programas da Assistência Estudantil, este deverá obedecer rigorosamente as regras dos editais divulgados pelo DAC. Os editais são lançados a cada semestre do ano letivo. Os estudantes que queiram participar dos programas deverão ser escrever pelo site http://www.saeweb.unb.br e entregar cópias dos documentos solicitados nos editais na DDS, para avaliação socioeconômica dos estudantes pela equipe de assistentes sociais da UnB. 
Os programas da Assistência Estudantil da UnB são regidos, em sua maioria, por Resoluções que regulam o funcionamento dos programas e a concessão de benefícios.

O Programa Bolsa Permanência foi criado em 1997 por meio da Resolução no 001/1997, da Reitoria da UnB, que estabeleceu normas para concessão, renovação e administração do Programa de Bolsa de Permanência, a qual objetivava proporcionar suporte financeiro que garantisse a permanência e proporcionasse condições favoráveis ao rendimento acadêmico satisfatório, ao aluno com dificuldades financeiras para manutenção dos seus estudos em curso de graduação. Em contrapartida, o beneficiado prestava serviços na Universidade por meio de atividades que contribuíam para o desenvolvimento profissional dentro da sua área de formação. A Bolsa Permanência, por meio desta Resolução, era concedida mensalmente ao aluno previamente selecionado pela DDS, e o tempo máximo de duração não poderia exceder o período de duração média do seu curso de graduação. Os alunos selecionados eram supervisionados por um professor orientador que emitia, semestralmente, parecer sobre o desempenho do bolsista.

A Resolução $n^{\circ}$ 14/2009 tem a sua particularidade por atualizar os valores monetários e a quantidade de Bolsas Permanência ofertada pela UnB. O quantitativo de bolsas passou de 300 para 500, e o valor de $\mathrm{R} \$ 300,00$ (trezentos reais) para $\mathrm{R} \$ 465,00$ (quatrocentos e sessenta e cinco reais) - valor atualmente praticado.

O Governo Federal, por meio da Portaria no 389/2013, do Ministério da Educação (MEC) solicitou que as Instituições Federais de Ensino Superior (IFES) que possuem o programa de auxílio econômico denominado "Bolsa Permanência" deixassem de utilizar tal nomenclatura, que passaria a ser de uso exclusivo daquele Ministério. A referida Portaria também visou minimizar as desigualdades sociais e contribuir para a diplomação dos estudantes economicamente vulneráveis. O programa advindo desta Portaria tinha por gerência o próprio MEC. Desde então, e pela Resolução $n^{\circ}$ 12/2014, do CAD/UnB, o programa passou a ser denominado de Programa Auxílio Socioeconômico da UnB (PASeUnB). Tal Resolução revogou a de nº 01/1997.

De acordo com a Resolução $n^{\circ} 12 / 2014$, do CAD/UnB, que cria o PASeUnB, os objetivos do programa deverão estar de acordo com o Decreto do PNAES e ainda contribuir com a redução de vagas ociosas decorrentes de insuficiência financeira. O estudante que for beneficiado pelo PASeUnB pode acumular com mais uma bolsa ou auxilio, decorrente de desenvolvimento de atividades de ensino, pesquisa e extensão da UnB ou de programas como, por exemplo, o Programa Institucional de Bolsas de Iniciação Científica (PIBIC), mas a soma total dos valores não pode ultrapassar um salário mínimo e meio. $\mathrm{O}$ estudante beneficiado 
poderá acumular também outros auxílios fornecidos pela Assistência Estudantil, mas também não pode ultrapassar a soma de um salário mínimo e meio, com exceção dos campi que não possuem RU.

Para receber o PASeUnB, o estudante deve estar matriculado em curso de graduação presencial no mínimo de crédito do fluxo de seu curso no semestre, conforme o Projeto Político Pedagógico (PPP), não ser portador de diploma de curso superior, não ultrapassar dois semestre do tempo regulamentar do referido curso e não participar do programa Bolsa Permanência do MEC. Caso o estudante apresente dois ou mais trancamentos de disciplinas e notas inferiores a "MM", este será encaminhado ao Serviço de Orientação ao Universitário do Decanato de Ensino de Graduação da Universidade de Brasília (SOU/DEG/UnB).

O estudante poderá ser desligado do $\mathrm{PASeUnB}$ a pedido, se não se matricular no quantitativo mínimo do PPP do curso, por abandono, exclusão ou desligamento do curso. Perderá o direito do benefício aquele que omitir, fraudar ou falsificar a documentação entregue na DDS e quando houver pena disciplinar ao estudante conforme o Regimento Geral da UnB.

O estudante beneficiado pelo Programa Auxílio Socioeconômico da UnB deverá elaborar atividades de cunho formativo e integrador no âmbito da referida Universidade.

O programa de alimentação da UnB para os estudantes assistidos pela DDS é classificado em duas modalidades, a saber: 1) o Bolsa Alimentação, que lhe concede o direito de refeições gratuitas onde existir RU; e, 2) o Auxílio Alimentação, onde o contemplado recebe o benefício em pecúnia.

A Resolução no 138/2012, da Reitoria da UnB, estabeleceu o Programa Bolsa Alimentação com o objetivo de garantir alimentação básica aos estudantes que se encontram em vulnerabilidade econômica com a finalidade de sua manutenção na UnB. Para ter direito ao benefício, o estudante deverá estar regulamente matriculado em disciplinas presenciais e ser identificado pela DDS como estudante do grupo de vulneráveis. Para usufruir do benefício, o estudante deverá apresentar a identidade estudantil no acesso aos refeitórios do restaurante. Estes poderão se alimentar no RU e ter direito a três refeições diárias: desjejum, almoço e jantar. O estudante beneficiado que burla o sistema de acesso ao RU ou fizer uso inadequado da identidade estudantil para benefício de terceiros terá o direito suspenso por 30 dias uteis.

A Resolução no 139/2012, também da Reitoria da UnB, garante o ressarcimento aos participantes do Programa Bolsa Alimentação durante os períodos prolongados de não funcionamento do RUs, como, por exemplo, greve e outros motivos, com o intuito de 
minimizar o impacto financeiro gerado aos alunos beneficiários da bolsa nestes períodos. Vale ressaltar que somente os estudantes contemplados com o Programa Bolsa Alimentação, Moradia e os campi onde existir RU terão o direito de ressarcimento.

Ainda sobre o Programa Bolsa Alimentação, a Resolução nº 52/2013, do CAD/UnB, define que os estudantes pertencentes àquele grupo serão isentos de cobranças ou taxas nas refeições servidas nos RUs.

O Programa Auxílio Alimentação, instituído em 2009 por meio da Resolução no 55 e atualizado pela Resolução no 21/2011, da Reitoria da UnB, concede o auxílio aos estudantes beneficiados pela Assistência Estudantil regularmente matriculados nos cursos de graduação presenciais nos campi FCE, FUP e FGA, por não possuírem RUs. O auxílio é concedido apenas durante o semestre letivo ou para aqueles estudantes que comprovarem atividades acadêmicas no período de férias, e cessará após a construção dos restaurantes em cada campus e desde que esteja em pleno funcionamento.

A Resolução no 026/2013, que criou e normatizou o Auxílio Emergencial, foi revogada pela Resolução no 109/2013, também da Reitoria da UnB, que dispõe e atualiza a concessão do referido benefício, destinado aos estudantes em dificuldades socioeconômicas emergenciais, inesperadas e momentâneas, o qual colocam em risco a sua permanência na Universidade. Tal auxílio pode ser pago por no máximo três meses e prorrogado por no máximo mais três meses no mesmo ano letivo. O Assistente Social que conceder o benefício deverá acompanhar a situação econômica e social do estudante. O valor do auxílio é o mesmo valor daquele preconizado pelo PASeUnB.

O Auxílio Emergencial destaca-se dos demais programas por atender aos estudantes que não recebem bolsa ou auxílio dos programas da Assistência Estudantil da UnB, ou seja, são aqueles estudantes que não estão contemplados nos programas da DDS, mas necessitam de amparo institucional para garantir a sua manutenção ou diminuir os riscos de evasão destes estudantes da UnB.

A preocupação pela moradia estudantil teve início nas Resoluções ns. 03/1974, 04/1988, 06/1988, 02/2002, do CAD/UnB, e por meio do Ato da Reitoria $n^{\circ} 1792 / 1997$, os quais foram revogados pela Resolução no 06/2008, também do CAD/UnB, que permaneceu válida até 31 de agosto de 2014 . O novo Ato da Reitoria que regulamenta o funcionamento da Casa do Estudante Universitário é o de $n^{\circ} 1200$, de $1^{\circ}$ de setembro de 2014. 
O Programa de Moradia Estudantil de Graduação (PME-G) visa contribuir para o desempenho acadêmico e a permanência dos estudantes selecionados, com a finalidade de reduzir os custos de manutenção de vagas ociosas decorrentes das desigualdades econômicas. Neste sentido, tem-se a CEU, que é composta por dois blocos com 90 apartamentos cada, e com quatro vagas em cada um deles, totalizando 360 vagas. Os apartamentos são equipados de móveis e eletrodomésticos, a fim de garantir condições mínimas de moradia. Têm-se ali dois apartamentos adaptados para atender preferencialmente aos estudantes portadores de deficiências. As vagas serão para os estudantes de graduação presenciais cujas famílias residam fora do Distrito Federal e nem possuam imóveis nesta Unidade da Federação (UF).

A CEU é patrimônio da UnB e os seus residentes deverão zelar pelo bem público. Assim, os moradores que causarem danos ou prejuízos patrimoniais deverão ressarcir ao erário e, quando da não identificação do responsável que causar qualquer tipo de prejuízo ali identificado, será rateado o valor do prejuízo entre os ocupantes do respectivo apartamento. Os móveis e os equipamentos serão de responsabilidade dos moradores. O beneficiário ou exbeneficiário do PME-G que constar alguma pendência em seu nome, não terá o "nada consta" e ficará impedido da sua conclusão do curso ou renovação do programa de moradia.

O tempo máximo de permanência do estudante é de até dois semestres além do tempo regular do seu curso. Não poderão hospedar amigos e parentes com exceção dos estudantes deficientes que necessitem dos seus cuidadores. O estudante poderá perder a vaga quando da ocorrência das seguintes hipóteses: ausentar-se da CEU por mais de 15 dias consecutivos, mesmo em período de férias, se não tiver a anuência da administração da CEU, ou em caso de desobediência das regras de convivência da CEU. O estudante desligado do Programa deverá liberar a vaga no prazo de dez dias corridos. A vaga será preenchida por estudante classificado e que ainda não foi contemplado, obedecendo rigorosamente a ordem de classificação.

Para amparar os estudantes que participam do PME-G foi delegado ao DAC assinar contratos com os discentes por meio do Ato da Reitoria ${ }^{\circ}$ 114/2011, para lhes assegurar o direito de moradia durante a reforma da CEU. O estudante poderá optar em escolher a contratação de locação de imóvel pela FUB ou receber o Auxílio Moradia. A locação de imóvel cessará após a reinauguração da CEU.

Neste sentido, foi instaurada a Resolução $n^{\circ} 118 / 2012$, da Reitoria da UnB, que estabelece critérios de efeito suspensivo da Assistência Estudantil para estudantes que não estejam regularmente matriculados em disciplinas dos cursos presenciais de graduação, mas 
foi revogada pela Resolução $n^{\circ} 76 / 2013$, do CAD/UnB, uma vez que cada programa existente e regulamentado disponibiliza os critérios de suspensão em suas Resoluções ou Atos.

A seguir, tem-se um histórico recente sobre o quantitativo de estudantes beneficiados pela Assistência Estudantil, expressos nas Tabelas 14 a 18.

Tabela 14 - Número de beneficiados da Assistência Estudantil da Universidade de Brasília.

\begin{tabular}{lc}
\hline Ano & Número de Estudantes \\
\hline 2008 & 570 \\
2009 & 1207 \\
2010 & 1183 \\
2011 & 1972 \\
2012 & 2604 \\
2013 & 3216 \\
2014 & 3058 \\
\hline
\end{tabular}

Fonte::UnB (2014b).

Conforme a Tabela 14, é possível identificar que o número de estudantes cresceu em torno de 5,6 vezes, quando comparado o ano de 2013 com o de 2008, em decorrência dos recursos oriundos do PNAES. O quantitativo de 2014 é referente até o mês de setembro, ou seja, é referente ao primeiro semestre e não contempla o segundo semestre, sendo um dos motivos da apresentação de um número inferior a 2013. Em 2010, houve uma redução de beneficiados devido à paralisação de 187 dias dos servidores técnicos da UnB, o que dificultou os processos de trabalho da Assistência Estudantil.

Os recursos do PNAES para a UnB foram distribuídos conforme os dados expressos na Tabela 15 , a seguir.

Tabela 15 - Recursos do Programa Nacional de Assistência Estudantil para a Universidade de Brasília.

\begin{tabular}{ll}
\hline Ano & Valor $(\mathbf{R} \$)$ \\
\hline 2008 & $913.186,95$ \\
2009 & $6.986 .976,00$ \\
2010 & $8.341 .577,51$ \\
2011 & $12.062 .803,78$ \\
2012 & $13.971 .718,45$ \\
2013 & $16.560 .796,58$ \\
2014 & $26.075 .259,12$ \\
Total & $84.912 .318,39$ \\
\hline
\end{tabular}

Fonte: Adaptado de Brasil (2014). 
Diante do exposto, é possível observar um aumento consubstancial de recursos financeiros destinado para a Assistência Estudantil da UnB. Anteriormente ao PNAES, os recursos eram bastante escassos e não possibilitavam a criação de novos programas e tampouco o aumento do número de beneficiados.

O PNAES possibilitou a criação de novos programas, bem como o aumento quantitativo de beneficiados dos programas que já existiam. Destaca-se o ano de 2014, quando a UnB aderiu ao ENEM.

O PASeUnB foi um dos programas que mais se destacou após a implementação do PNAES. O PASeUnB concede recursos financeiros aos estudantes economicamente vulneráveis com a finalidade de suprir as necessidades de manutenção na universidade.

Tabela 16 - Número de beneficiados - Programa de Auxílio Socioeconômico da Universidade de Brasília.

\begin{tabular}{cccc}
\hline Ano & Número de Bolsas Concedidas & Demanda Reprimida & Cotas Disponíveis \\
\hline 2008 & 300 & - & - \\
2009 & 300 & - & - \\
2010 & 450 & 66 & 450 \\
2011 & 1006 & 387 & 1006 \\
2012 & 1206 & 247 & 1206 \\
2013 & 1480 & 291 & 1480 \\
Total & 4142 & 991 & 4142 \\
\hline
\end{tabular}

Fonte:UnB (2014b).

A concessão deste auxílio anterior ao PNAES era financiada com recursos federais destinados à manutenção do estudante, o que era aquém da necessidade e retirava a possibilidade de aplicação de parte destes recursos em setores acadêmicos. Os recursos do Programa eram mais limitados e concediam até o máximo de 300 bolsas. Os dados obtidos revelam que havia pouca preocupação com o planejamento do Programa, pois não foi possível a obtenção dos seguintes dados dos anos de 2008 e 2009: demanda reprimida e cotas disponíveis. Para a obtenção destes dados, seria necessário analisar todos os estudos socioeconômicos dos respectivos anos, para, assim, obter os dados incompletos.

A partir do ano de 2010, os dados passaram a ser registrados, o que possibilitou no planejamento para a concessão de novas bolsas e verificação do número de estudantes que possuem o perfil para o referido Programa. 
A oferta de bolsas em 2013 cresceu mais de três vezes, quando comparado com o ano de 2010 e, ainda assim, existiu demanda reprimida. Por meio destes dados, o DAC e a DDS podem promover novas políticas para o respectivo Programa.

Tabela 17 - Programa de alimentação.

\begin{tabular}{cccccc}
\hline \multirow{2}{*}{ Ano } & \multicolumn{3}{c}{ Campus } & Total \\
\cline { 2 - 5 } & Darcy & FUP & FGA & FCE & \\
\hline 2008 & 570 & - & - & - & 570 \\
2009 & 899 & 189 & 50 & 69 & 1207 \\
2010 & 788 & 223 & 69 & 103 & 1183 \\
2011 & 1322 & 320 & 142 & 188 & 1972 \\
2012 & 1735 & 404 & 165 & 300 & 2604 \\
2013 & 1737 & 725 & 294 & 460 & 3216 \\
2014 & 1886 & 620 & 247 & 305 & 3058 \\
Total & 9806 & 2481 & 967 & 1425 & 14679 \\
\hline
\end{tabular}

Fonte:UnB (2014b).

O Programa de Alimentação era ofertado apenas no campus Darcy Ribeiro e, com a implementação do PNAES, foi possível levá-lo aos demais campi e ampliar a oferta do benefício (que pode ser o Auxílio-Alimentação ou a Bolsa Alimentação).

Outra ação conquistada devido ao PNAES foi a implementação do Auxílio Emergencial, o qual destina recursos financeiros para suprir necessidades não eventuais e que são de extrema importância para a permanência do estudante na UnB. Na Tabela 18, a seguir, tem-se os dados deste auxílio desde a sua criação.

Tabela 18 - Auxílio emergencial.

\begin{tabular}{lc}
\hline Ano & Auxílios Concedidos \\
\hline 2011 & 150 \\
2012 & 294 \\
2013 & 386 \\
\hline
\end{tabular}

Fonte::UnB (2014b).

Analisando a situação da UnB por meio de dados e Resoluções que versam sobre o tema "Assistência Estudantil", percebeu-se que a Instituição tem o cuidado de definir as regras para concessão de bolsas, auxílios e benefícios, porém, durante a pesquisa empreendida, não foi encontrado nenhum documento que demonstrasse os resultados dos 
programas, ou seja, não se sabe quanto todo o esforço em oferecer a Assistência Estudantil fez de diferença na evasão e retenção da Instituição, que é o objetivo primordial do PNAES.

\subsection{Perfil dos estudantes assistidos pela Universidade de Brasília}

A DDS/DAC/UnB possui o Sistema da Assistência Estudantil Web (SAEWeb), desenvolvido pelo seu Centro de Processamento de Dados (CPD). O sistema é responsável pelos dados dos estudantes participantes da Assistência Estudantil da UnB. A descrição do perfil dos estudantes assistidos será baseada nos dados extraídos do SAEWeb.

O perfil será descrito com base nos dados obtidos em 05 de setembro de 2014. Os dados mencionados nesta seção poderão ser conferidos no Anexo B logo adiante.

O estudo socioeconômico se dá por profissionais do Serviço Social. Os dados do SAEWeb demonstram que naquele momento, 3.274 estudantes se inscreveram para participarem dos programas da DDS, mas somente 3.058 estudantes possuíam perfil socioeconômico para participarem de algum dos programas ofertados pela UnB. Portanto, tem-se que 93,4\% dos estudantes que procuram o serviço de Assistência Estudantil carecem de algum tipo de ajuda para se manterem na UnB. Entre os estudantes contemplados, a maioria é do sexo feminino, com 1.761 estudantes (57,6\% dos discentes beneficiados), e o sexo masculino tem representatividade de 1.297 estudantes $(42,4 \%$ dos discentes beneficiados).

O SAEWeb classifica a raça dos estudantes em cinco tipos, quais sejam: amarela, preta, parda, branca e indígena. A raça parda é a maior beneficiada pelos programas da UnB, com 1493 estudantes, seguida pelas raças branca (788 estudantes), preta (646 estudantes), amarela (com 91 estudantes) e indígena (com 40 estudantes). A raça parda destaca-se como a de maior percentual dos beneficiados, com 48,8\%, e a raça indígena é a menos representativa, com apenas 1,3\% dos beneficiados. Os dados da UnB divergem pouco quando comparado com os dados do Censo de 2010 do Instituo Brasileiro de Geografia e Estatística (IBGE), onde a população brasileira de raça branca é a predominante, com 47,7\%, seguida pelas raças parda $(43,3 \%)$, preta $(7,6 \%)$, amarela $(1,05 \%)$ e indígena $(0,46 \%)$. Portanto, a participação dos beneficiados da Assistência Estudantil da UnB quanto à raça diverge em relação à população brasileira apenas nos dois primeiros lugares, pois há inversão nas ordens quando comparado à raça dos beneficiados da UnB e da população brasileira; nas demais posições, o comportamento é idêntico. 
O modo de ingresso dos referidos estudantes na UnB chama a atenção, pois, do total de 3.058 estudantes que participam da Assistência Estudantil, 2.067 ingressaram pelo modo universal, o que representa $67 \%$, e apenas $33 \%$ dos estudantes, ou seja, 991 estudantes, usufruíram de alguma modalidade de cota para entrar na UnB.

Os tipos de cotas e o número de estudantes beneficiados foram distribuídos da seguinte maneira: cota para negros, com 422 estudantes $(13,8 \%)$; estudantes oriundos de escolas públicas de baixa renda - Pretos, Pardos e Indígenas (PPI), 209 discentes (6,8\%); escola pública alta renda - PPI, 143 discentes (4,7\%); estudantes procedentes de escola pública baixa renda - não PPI, 115 discentes $(3,8 \%)$; estudante de escola pública de alta renda - não PPI, 73 discentes (2,4\%); e, cota indígena, 29 discentes $(0,9 \%)$ que recebem benefícios da UnB.

A UnB possui quatro campi e a distribuição de beneficiários da Assistência Estudantil se dá na seguinte ordem: campus Darcy Ribeiro, com 1.886 beneficiários (61,7\%); campus FUP, com 620 beneficiários (20,3\%); campus FCE, com 305 beneficiários (10\%); e, campus FGA, com 247 beneficiários $(8,1 \%)$ de algum dos programas da Assistência Estudantil.

Os dados do SAEWeb demonstram a existência de beneficiados em 102 cursos de graduação e sua distribuição não se dá de forma homogênea. O SAEWeb é um programa elaborado pela UnB com a finalidade de armazenar dados da Assistência Estudantil, porém, este não permite a extração de dados por semestre ou por ano, demonstrando apenas os estudos socioeconômicos válidos no momento. Estudantes que tiverem seus estudos vencidos, que abandonaram os cursos ou se formaram são excluídos automaticamente da base de dados do SAEWeb. Assim, os dados informados referem-se aos estudantes que receberam algum tipo de benefício da Assistência Estudantil no ano de 2014 até o mês de setembro, e não se trata do acumulado da implementação do PNAES. Tais dados somente seriam possíveis com a pesquisa documental de todos os estudos socioeconômicos da UnB desde a implementação do PNAES, o que demandaria muito tempo para o levantamento destes dados.

Neste sentido, faz-se importante ressaltar os três cursos com o maior número de beneficiados e os três últimos cursos em número de beneficiários para efeito de ilustração. Tem-se, portanto, os cursos de Ciências Naturais (221 estudantes beneficiados - 7,23\%), Letras (com 162 estudantes beneficiados - 5,30\%) e Educação do Campo (com 147 estudantes beneficiados $-4,81 \%$ ), que apresentam discentes que recebem algum benefício da Assistência Estudantil da UnB. Os últimos colocados em benefícios são os cursos de Transporte, Tecnologia Ambiental e Recursos Hídricos, e Psicologia Social do Trabalho e das 
Organizações, com apenas um estudante beneficiado $(0,33 \%)$ em cada um destes cursos que recebem algum benefício.

É importante destacar o quantitativo de beneficiados de cursos orientados para o desenvolvimento econômico, conforme preconiza a PINTEC, que são os setores de software, semicondutores, bens de capital e fármacos. Tais setores concentram-se basicamente nas áreas do conhecimento de Engenharias e Ciências da Saúde. Neste sentido, constatou-se a distribuição conforme se segue: Engenharia (103 estudantes beneficiados - 3,37\%), Engenharia de Energia (41 estudantes beneficiados - 1,34\%), Engenharia Eletrônica (39 estudantes beneficiados - 1,28\%), Engenharia de Software (29 estudantes beneficiados 0,95\%), Engenharia Mecatrônica (23 estudantes beneficiados - 0,75\%), Engenharia Civil (19 estudantes beneficiados - 0,62\%), Engenharia Aeroespacial (18 estudantes beneficiados 0,59\%), Engenharia Automotiva (17 estudantes beneficiados - 0,56\%), Engenharia Elétrica (17 estudantes beneficiados - 0,56\%), Engenharia Mecânica (13 estudantes beneficiados 0,43\%), Engenharia de Redes de Comunicação (10 estudantes beneficiados - 0,33\%), Ciência da Computação (07 estudantes beneficiados - 0,23\%), Engenharia de Computação (07 estudantes beneficiados - 0,23\%), Engenharia de Sistemas Eletrônicos e de Automação (02 estudantes beneficiados -0,07\%), Farmácia (71 estudantes beneficiados - 2,32\%) e Ciências Farmacêuticas (09 estudantes beneficiados - 0,29\%). Esses são os cursos ofertados pela UnB com maiores probabilidades de aumento da eficiência e desenvolvimento econômico nacional.

$\mathrm{O}$ resumo do perfil dos estudantes da UnB beneficiados com algum programa da Assistência Estudantil pode ser descrito da seguinte maneira: a maioria é do sexo feminino, ou seja, 57,6\% dos discentes beneficiados; a raça predominante é a parda, com quase metade dos beneficiários $(48,8 \%)$. A maior parte dos estudantes assistidos ingressaram na UnB por meio do sistema universal e apresentaram um índice elevadíssimo de $67,6 \%$, e somente $32,4 \%$ destes ingressaram por meio de cotas. O sistema de cotas com mais representatividade na Assistência Estudantil é o de cotas para negros, com 13,8\%. Os cursos orientados para o desenvolvimento econômico nacional absorvem 13,90\%, e o campus Darcy Ribeiro representa $61,7 \%$ dos estudantes auxiliados com benefícios da Assistência Estudantil da UnB.

\subsection{Trancamento de matrículas e desligamento estudantil da Universidade de Brasília}

Faz-se importante aqui comparar os dados da Secretária de Administração Acadêmica (SAA) da UnB e verificar em termos numéricos como está sendo o comportamento da Universidade depois da institucionalização do PNAES. A análise que se segue aborda o 
período de 2002 até o $1^{\circ}$ semestre de 2014, com as variáveis "estudantes regularmente matriculados", "desligamentos" e "algumas formas de trancamento de matrículas". A série histórica contemplará antes e após a implementação REUNI/PNAES.

Os dados apresentados são exclusivos dos cursos de graduação da UnB. No início do período analisado, a Universidade possuía 19.978 estudantes regularmente matriculados e, em 2007, quando do surgimento do REUNI, esta contava com 22.015 estudantes regularmente matriculados. Tal acréscimo representa um crescimento de 10,2\% em relação ao ano base.

A expansão universitária da UnB teve início em 2008, com a aplicação de recursos do REUNI, e se deu por meio de ampliação de vagas nos cursos de graduação, criação de cursos noturnos e construção de novos prédios e dos campi FCE, FGA e FUP. Por meio da política expansionista, a UnB, no primeiro semestre de 2014, estava com 36.027 estudantes regulamentes matriculados, ou seja, 15.385 estudantes a mais quando comparado com o final do ano de 2007, o que representa um crescimento percentual de $75 \%$ após a implementação do REUNI.

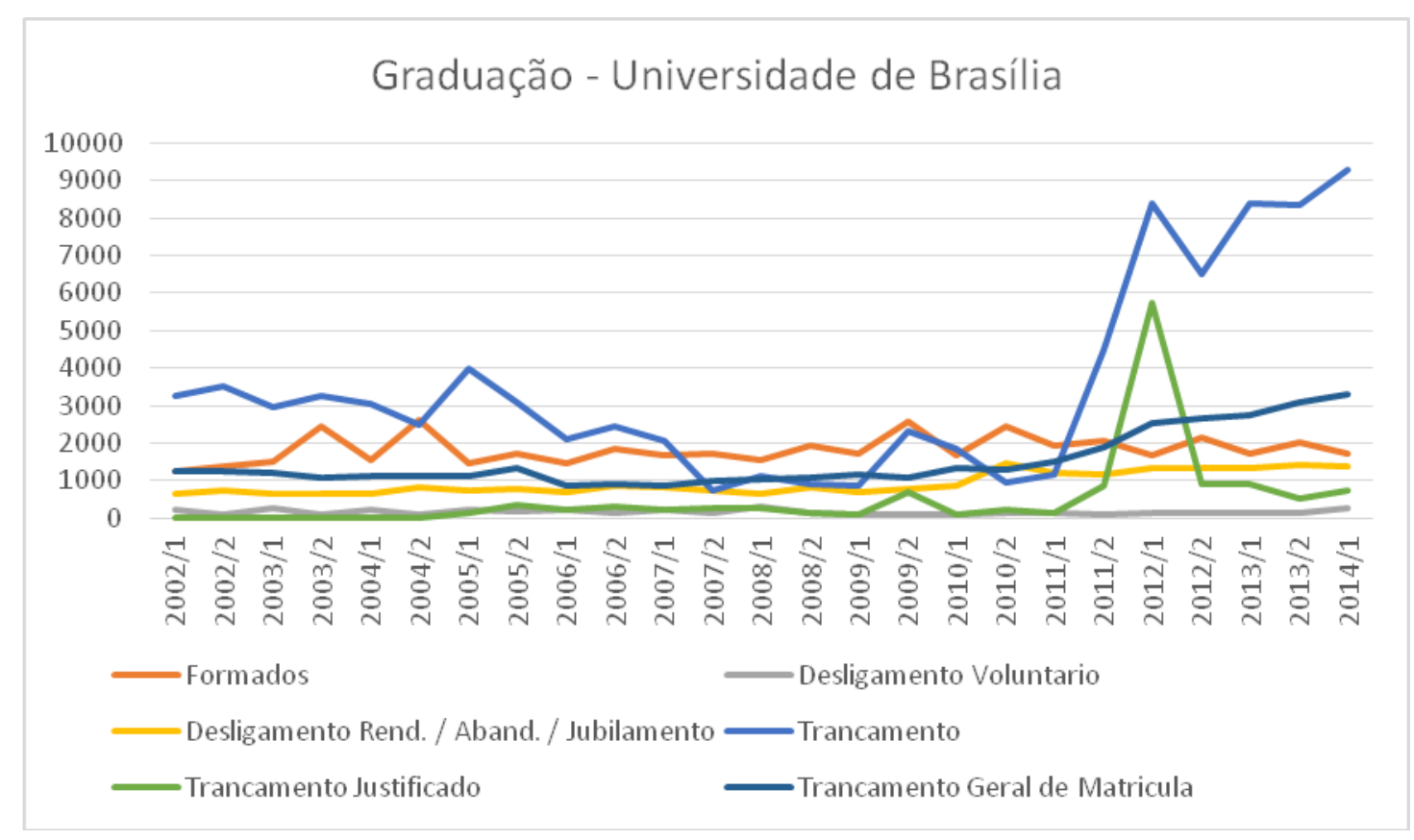

Gráfico 3 - Formados, trancamentos e desligamentos.

Fonte: Adaptado de UnB (2014a).

Os dados que mais interessam no presente estudo são aqueles referentes à retenção e evasão dos estudantes da UnB. Primeiramente, tem-se uma análise dos dados sobre os 
formados. Para tanto, calculou-se a média dos formados antes e após a implementação do REUNI/PNAES. Assim, a média pré Programas foi de 1.712 discentes formados por semestre; e a média sobe um pouco após a implementação dos referidos Programas, mas quando a comparação se dá pela média percentual em relação aos estudantes regulamente matriculados, o índice pré REUNI/PNAES apresenta melhor taxa de concluintes, com 8,5\% contra 6,6\% após os dois programas federais de expansão e manutenção dos estudantes das IFES. 
Tabela 19 - Média de trancamentos de matrículas e desligamentos.

\begin{tabular}{|c|c|c|c|c|c|}
\hline Itens & $\begin{array}{c}\text { Média Pré-REUNI/PNAES } \\
\text { (2002 a 2007) }\end{array}$ & $\begin{array}{c}\text { Média Pós-REUNI/PNAES } \\
\text { (2008 a 2014) }\end{array}$ & $\begin{array}{c}\text { Média Percentual Pré- } \\
\text { REUNI/PNAES (2002 a 2007) }\end{array}$ & $\begin{array}{c}\text { Média Percentual Pós- } \\
\text { REUNI/PNAES (2008 a 2014) }\end{array}$ & Diferença Percentua \\
\hline Total de Alunos Regulares & 20032 & 29442 & 20032 & 29442 & $46,98 \%$ \\
\hline Formados & 1712 & 1933 & $8,55 \%$ & $6,56 \%$ & $-1,98 \%$ \\
\hline Desligamento Voluntario & 180 & 144 & $0,90 \%$ & $0,49 \%$ & $-0,41 \%$ \\
\hline $\begin{array}{l}\text { Desligamento } \\
\text { Rend./Aband./Jubilamento }\end{array}$ & 732 & 1107 & $3,65 \%$ & $3,76 \%$ & $0,11 \%$ \\
\hline Trancamento & 2744 & 4205 & $13,70 \%$ & $14,28 \%$ & $0,58 \%$ \\
\hline Trancamento Justificado & 131 & 864 & $0,65 \%$ & $2,93 \%$ & $2,28 \%$ \\
\hline Trancamento Geral de Matricula & 1097 & 1898 & $5,48 \%$ & $6,45 \%$ & $0,97 \%$ \\
\hline
\end{tabular}

Fonte: Adaptado de UnB (2014a). 
Para os dados de evasão dos estudantes da UnB, o presente estudo concentrou-se nas variáveis "trancamento de matrículas" e "desligamentos". O trancamento pode ser dado em três modos, a saber: trancamento, trancamento justificado e trancamento geral de matrícula.

O trancamento médio de matrículas pré Programas foi de 2.744 contra 4.205 trancamentos, representando um aumento de 53\% neste tipo de evento. Ao se comparar o trancamento pré e pós PNAES em relação à média de estudantes regulamente matriculados, têm-se os percentuais de $13,7 \%$ e 14,3\%, respectivamente. Para o trancamento justificado, a diferença é ainda maior quando comparado os dois períodos, ou seja, houve um crescimento de seis vírgula cinquenta e nove vezes após a adesão da UnB aos programas de expansão e de manutenção dos estudantes das IFES, com a média de 131 trancamentos justificados para 864 trancamento na modalidade justificada, a diferença percentual entre os períodos é de 2,28\%. A última modalidade de trancamento é a geral de matrículas, onde se tem uma piora do índice em relação aos períodos com crescimento de $73 \%$ neste tipo de trancamento. O trancamento geral de matrículas tem a média de 5,5\% dos estudantes regulamente matriculados e, logo após a política de expansão e democratização do Ensino Superior, o percentual passou para $6,5 \%$ em relação à média dos estudantes matriculados. Neste sentido, é possível perceber uma piora nas três modalidades de trancamento quando comparado os períodos pré e pós implementação do REUNI/PNAES.

O desligamento é uma das variáveis que pode ser utilizada para verificar o resultado do PNAES na UnB. O Sistema de Graduação (SIGRA) permite analisar duas modalidades de desligamento, quais sejam: o desligamento voluntário e o desligamento por rendimento, abandono e jubilamento.

O desligamento voluntário, no início do período aqui analisado, contava com 226 casos e representava $0,011 \%$ dos estudantes regulamente matriculados e, no final da série, primeiro semestre de 2014, registrou 273 casos. A comparação dos períodos pré e pós Programas revela uma pequena melhoria, sendo a média de 180 estudantes, o que representa 0,010\%, contra a média de 144 estudantes, o que representa $0,005 \%$ dos estudantes regularmente matriculados.

O desligamento por falta de rendimento, abandono ou jubilamento teve crescimento pouco significativo após o REUNI/PNAES, ou seja, a média foi de $0,0365 \%$ para $0,0376 \%$, em comparação com a média dos alunos regulares.

Difere-se, então, que após a implementação do PNAES, houve melhoria apenas na variável "desligamento voluntário", apresentando índices deficitários nas demais variáveis pesquisadas. 


\section{CONCLUSÃO}

O Programa Nacional de Assistência Estudantil (PNAES) é um programa de cunho social com a finalidade de dar condições de diplomação aos estudantes economicamente vulneráveis das Instituições Federais de Ensino Superior (IFES) e de diminuir as desigualdades socioeconômicas do Brasil.

O critério utilizado pelo PNAES para repassar o recurso financeiro às IFES consiste na adesão destas ao Sistema de Seleção Unificada (SiSU)/ENEM, o que se opõe a um dos seus objetivos: diminuir as desigualdades sociorregionais. A Universidade que reservar cem por cento de suas vagas pela seleção do ENEM receberá cem por cento dos recursos do PNAES, a que reserva $50 \%$ das vagas pelo SiSU/ENEM receberá $75 \%$ dos recursos orçamentário do PNAES, a IFES que utilizar parcialmente esse método de seleção receberá $50 \%$ do PNAES e nos demais casos a IFES receberá 25\% dos recursos do PNAES. Para tanto, a distribuição orçamentária deveria ser feita de forma inversamente proporcional à média do Índice de Desenvolvimento Humano (IDH) da região para as IFES, de modo que as instituições das regiões com menor IDH receberiam maior quantidade de recursos financeiros para a Assistência Estudantil. Porém, detectou-se que os recursos e números de benefícios distribuídos e financiados pelo PNAES não estão de acordo com o preceito do IDH.

Outro ponto analisado é o percentual de investimento na educação superior brasileira em relação ao Produto Interno Bruto (PIB), que demonstrou ser menor do que a média dos países que compõem a Organização para a Cooperação e Desenvolvimento Econômico (OCDE), e que pode ser observado também no investimento per capita neste nível de ensino, isso acarreta deficiências na produção de bens e serviços brasileiros por não possuírem mãode-obra adequada, tornando-se assim um parque industrial fraco para a contribuição do desenvolvimento econômico do país.

As IFES possuem papel fundamental para a formação da sociedade brasileira e para o desenvolvimento econômico nacional, pois são formadoras de capital humano e uma das maiores responsáveis pela produção de patentes do país.

A população adulta brasileira, entre 25 a 64 anos, é composta de $12 \%$ com nível superior de ensino, e a OCDE apresenta o índice de 32\%. A diferença na formação da população adulta pode ser umas das causas que compromete a qualidade de vida, a capacidade técnica e o desenvolvimento humano. A taxa de empregabilidade no Brasil aos portadores de diploma superior é maior do que a média dos países que compõem a OCDE, além de oferecer média salarial extremamente superior quando comparado à média salarial do Ensino Médio da 
população brasileira. Constata-se, então, que o Ensino Superior é um dos principais fatores para a ascensão social brasileira.

A Taxa Interna de Retorno da Educação brasileira apresenta índices elevados e destaca-se o ensino superior por ser o único nível de ensino a apresentar elevação dessa taxa. O Estado deve interferir e investir na educação, mesmo esse apresentado uma TIR elevada, pois, os vulneráveis economicamente não dispõem de recursos financeiros para investir e esperar o tempo de retorno desse investimento. Esses abandonam os estudos para trabalhar e auferir recursos imediatos para o seu sustento, diminuindo assim sua renda futura. O Estado deve oferecer condições mínimas para que os vulneráveis economicamente tenham condições de ascender socialmente por meio da educação.

O PNAES na UnB ampliou o número de benefícios, beneficiados e implementou novos programas para a manutenção de estudantes economicamente vulneráveis. Neste sentido, foi possível observar que 8,5\% dos estudantes regularmente matriculados na UnB recebem algum tipo de ajuda para se manterem na universidade, e a lei de cotas para a escola pública, implementada em 2012, reforça a necessidade do PNAES na UnB, pois, até 2016, $50 \%$ das vagas ofertadas deverão ser para escolas públicas, o que acarretará o ingresso maior de estudantes com situação econômica precária.

O PNAES na UnB financia os seguintes programas: Programa Auxílio Socioeconômico da Universidade de Brasília (PASeUnB), Auxílio Moradia, Auxílio Alimentação e Auxílio Emergencial, que contemplam apenas os itens "moradia", "alimentação" e "apoio pedagógico" previstos no $\S 1^{\circ}$, art. $3^{\circ}$ do Decreto Presidencial $n^{\circ}$ 7.234/2010, porém, não promove ações de cunho cultural, transporte, saúde, inclusão digital, esporte e creche. Assim, concentra-se a aplicabilidade dos recursos em três áreas temáticas do PNAES, o que pode acarretar prejuízos aos estudantes nas áreas não cobertas pela UnB, conforme orienta o referido Decreto.

A pesquisa revela que a média de crescimento no número de estudante, pré Programa de Reestruturação e Expansão das Universidades Federais (REUNI) nos anos de 2002 a 2007, e após a implementação dos Programas correlatos cresceu em média 47\% e apresentou melhorias relativas apenas nos desligamentos voluntários. Algumas variáveis (formados, desligamento por rendimento/jubilamento, trancamento justificado e trancamento geral de matrículas) apresentaram pioras relativas em seus índices. A diferença destas aumentou em 5,92\% após a implementação dos Programas. Destaca-se que o número absoluto de formados após a implementação dos Programas aumentou, mas diminuiu em termos relativos e uma das causas é a abertura de novos cursos que ainda não formaram turmas. Outro ponto que merece 
destaque é que o aumento relativo de abandono de cursos por falta de rendimento/jubilamento foi menor que os aumentos relativos nas modalidades de trancamentos. Portanto, após a implementação do PNAES houve redução no desligamento voluntário e a modalidade de desligamento por falta de rendimento/jubilamento apresentou elevação relativa inferior que os demais índices de evasão estudantil. De acordo com os dados ofertados pela UnB, não é possível identificar os reais motivos de trancamento ou desligamento, por exemplo: por não se identificar com o curso ou se por motivos financeiros o que deixaria a pesquisa mais completa. Percebeu-se a falta de estudos ou de trabalhos relativos ao PNAES na Universidade de Brasília sobre o desempenho do referido Programa.

A princípio, o PNAES parece não ter sido bem-sucedido em sua missão de manter o estudante na universidade, tendo em vista o acréscimo em alguns índices de evasão estudantil; mas, tais variáveis poderiam ter elevações ainda mais drásticas se não existisse o Programa devido a implementação do REUNI e da Lei de Cotas para escolas públicas.

Para existir a democratização do Ensino Superior brasileiro, é necessário o aumento de vagas, políticas afirmativas e programas de manutenção estudantil aos discentes economicamente vulneráveis.

A literatura sustenta que o investimento em educação proporciona externalidades positivas superiores a programas de distribuição de renda quando aplicado os mesmos valores orçamentários. Neste sentido, é mais vantajoso para o país investir em educação e formar capital humano para o amadurecimento de uma sociedade com base na economia do conhecimento.

O PNAES poderia contribuir de forma mais significativa para o crescimento econômico brasileiro impulsionando, priorizando ou promovendo ações para as áreas do conhecimento que são orientadas para o desenvolvimento econômico nacional. Entretanto, os dados demonstram que somente 13,90\% dos estudantes da Assistência Estudantil da Universidade de Brasília (UnB) estão matriculados em cursos com maiores probabilidades de alavancagem para o desenvolvimento econômico nacional. O PNAES pode contribuir de forma mais significativa para o desenvolvimento econômico nacional por meio de incentivos à formação específica de capital humano.

Conclui-se então que o PNAES é fundamental para a manutenção dos vulneráveis economicamente nas IFES sendo um instrumento essencial para a mobilidade educacional com a finalidade de corrigir ou minimizar as discrepâncias socioeconômicas brasileiras por meio da educação. Se o Estado abolir o Programa aumentará a evasão estudantil da IFES por conta da Lei de cotas para escolas públicas e consequentemente aumentará ainda mais a 
lacuna das desigualdades socioeconômicas entre ricos e pobres da população brasileira. $\mathrm{O}$ PNAES é um programa com retorno em longo prazo para a sociedade brasileira, mas é primordial para a diminuição da pobreza do Brasil no futuro.

Como um dos objetivos do PNAES é contribuir para a promoção da inclusão social pela educação, seria relevante que a UnB acompanhasse os egressos da Assistência Estudantil, a fim de verificar como se deu a inserção destes no mercado de trabalho e se houve melhorias nas suas condições socioeconômicas.

E ainda, sugere-se acompanhar o Programa após a efetiva implementação da Lei de Cotas para as escolas públicas, uma vez que tal fato poderá provocar desequilíbrio nas classes socioeconômicas da $\mathrm{UnB}$, pois aumentará o número de estudantes com deficiências econômicas em relação às questões concernentes à sua manutenção na Universidade, provocando mudanças na política assistencial para a manutenção destes, com o objetivo de evitar a evasão estudantil e o desperdício de recursos públicos com a geração de vagas ociosas. 


\section{REFERÊNCIAS}

ALBUQUERQUE, Claudiano Manoel de; MEDEIROS, Márcio Bastos; SILVA, Paulo Henrique Feijó. Gestão de Finanças Públicas: fundamentos e práticas de planejamento, orçamento e administração financeira com responsabilidade fiscal. 3. ed. Brasília: Gestão Pública, 2013. v. I.

ALVES, Jolinda Moraes. A Assistência Estudantil no âmbito da política de Ensino Superior pública. Serviço Social em Revista, Londrina, v. 5, n. 1. Jul./dez. 2002. Disponível em: <http://www.uel.br/revistas/ssrevista/c_v5n1_Jo.html>. Acesso em: 13 ago. 2014.

ARAÚJO, Josimeire O. O elo assistência e educação: análise assistência/desempenho no Programa Residência Universitária alagoana. 2003. Dissertação (Mestrado em Serviço Social) - Universidade Federal de Pernambuco, Recife, 2003.

ARAÚJO, M. P. Memórias estudantis: da fundação da UNE aos nossos dias. Rio de Janeiro: Relume Dumará, 2007.

ASSOCIAÇÃO BRASILEIRA DE EMPRESAS DE PESQUISA - ABEP. Índice mercadológico ABEP. 2010. Disponível em: <http://www.abep.org/new/Servicos/Download.aspx?id=05>. Acesso em: 24 ago. 2014.

BANCO MUNDIAL - BM. Índice de Gini. S. d. Disponível em: <http://wdi.worldbank.org/table/2.9>. Acesso em: 29 abr. 2014.

BECKER, Gary Stanley. Human capital: a theoretical and empirical: analysis, with special reference to education. 3. ed. New York: Nat Bur Econ Res, 1993.

BARBOSA FILHO, Fernando de Holanda; PESSÔA, Samuel. Retorno da Educação no Brasil. Pesquisa e Planejamento Econômico, v. 38, p. 97-126, 2008. Disponível em: <http://ppe.ipea.gov.br/index.php/ppe/article/viewFile/130/1024>. Acesso em: 15 mar. 2014.

BRASIL. Constituição da República dos Estados Unidos do Brasil (de 16 de Julho de 1934). Nós, os representantes do povo brasileiro, pondo a nossa confiança em Deus, reunidos em Assembléia Nacional Constituinte para organizar um regime democrático, que assegure à Nação a unidade, a liberdade, a justiça e o bem-estar social e econômico, decretamos e promulgamos a seguinte. Rio de Janeiro, 1934. Disponível em: <http://www.planalto.gov.br/ccivil_03/constituicao/constituicao34.htm>. Acesso em: 15 mar. 2015. 
Constituição da República Federativa do Brasil de 1967. Brasília, 1967. Disponível em: <http://www.planalto.gov.br/ccivil_03/constituicao/constituicao67.htm>. Acesso em: 15 mar. 2015.

Constituição dos Estados Unidos do Brasil (de 18 de Setembro de 1946). Rio de Janeiro, $1946 . \quad$ Disponível em: <http://www.planalto.gov.br/ccivil_03/constituicao/constituicao46.htm>. Acesso em: 15 mar. 2015.

Constituição Federal da República Federativa do Brasil de 1988. Brasília, 1988. Disponível em: <http://www.planalto.gov.br/ccivil_03/constituicao/constituicao.htm>. Acesso em: 15 mar. 2015.

Decreto $\mathrm{n}^{\mathbf{0}}$ 7.234, de 19 de julho de 2010. Dispõe sobre o Programa Nacional de Assistência Estudantil - PNAES. Brasília, 2010. Disponível em: <http://www.ifro.edu.br/site/wp-content/uploads/2015/02/Decreto-n\%C2\%BA-7234-2010Programa-Nacional-de-Assist\%C3\%AAncia-Estudantil-PNAES.pdf $>$. Acesso em: 15 abr. 2014.

Lei $n^{0} 10.973$, de 02 de dezembro de 2004. Dispõe sobre incentivos à inovação e à pesquisa científica e tecnológica no ambiente produtivo e dá outras providências. Brasília, 2004. Disponível em: <http://www.planalto.gov.br/ccivil_03/_ato20042006/2004/lei/l10.973.htm>. Acesso em: 15 mar. 2014.

Lei $n^{\circ}$ 11.196, de 21 de novembro de 2005. Institui o Regime Especial de Tributação para a Plataforma de Exportação de Serviços de Tecnologia da Informação REPES, o Regime Especial de Aquisição de Bens de Capital para Empresas Exportadoras - RECAP e o Programa de Inclusão Digital; dispõe sobre incentivos fiscais para a inovação tecnológica; altera o Decreto-Lei $n{ }^{\circ}$ 288, de 28 de fevereiro de 1967, o Decreto $n^{\circ}$ 70.235, de 6 de março de 1972, o Decreto-Lei $n^{\circ}$ 2.287, de 23 de julho de 1986, as Leis ns. 4.502, de 30 de novembro de 1964, 8.212, de 24 de julho de 1991, 8.245, de 18 de outubro de 1991, 8.387, de 30 de dezembro de 1991, 8.666, de 21 de junho de 1993, 8.981, de 20 de janeiro de 1995, 8.987, de 13 de fevereiro de 1995, 8.989, de 24 de fevereiro de 1995, 9.249, de 26 de dezembro de 1995, 9.250, de 26 de dezembro de 1995, 9.311, de 24 de outubro de 1996, 9.317, de 5 de dezembro de 1996, 9.430, de 27 de dezembro de 1996, 9.718, de 27 de novembro de 1998, 10.336, de 19 de dezembro de 2001, 10.438, de 26 de abril de 2002, 10.485, de 3 de julho de 2002, 10.637, de 30 de dezembro de 2002, 10.755, de 3 de novembro de 2003, 10.833, de 29 de dezembro de 2003, 10.865, de 30 de abril de 2004, 10.925, de 23 de julho de 2004, 10.931, de 2 de agosto de 2004, 11.033, de 21 de dezembro de 2004, 11.051, de 29 de dezembro de 2004, 11.053, de 29 de dezembro de 2004, 11.101, de 9 de fevereiro de 2005, 11.128, de 28 de junho de 2005, e a Medida Provisória no 2.199-14, de 24 de agosto de 2001; revoga a Lei $n^{0}$ 8.661, de 2 de junho de 1993, e dispositivos das Leis ns. 8.668, de 25 de junho de 1993, 8.981, de 20 de janeiro de 1995, 10.637, de 30 de dezembro de 2002, 10.755, de 3 de novembro de 2003, 10.865, de 30 de abril de 2004, 10.931, de 2 de agosto de 2004, e da Medida Provisória $n^{0} \mathbf{2 . 1 5 8 - 3 5}$, de 24 de agosto de 2001; e dá outras providências. 
Brasília, 2005. Disponível em: <http://www.planalto.gov.br/ccivil_03/_ato20042006/2005/lei/111196.htm>. Acesso em: 15 mar. 2014.

Lei $\mathrm{n}^{\circ}$ 12.711, de 29 de agosto de 2012. Dispõe sobre o ingresso nas universidades federais e nas instituições federais de ensino técnico de nível médio e dá outras providências. $\quad$ Brasília, 2012.2014 Disponível <http://www.planalto.gov.br/ccivil_03/_ato2011-2014/2012/lei/112711.htm>. Acesso em: 15 mar. 2014.

Ministério da Educação. Painel de Controle do MEC. 2014. Disponível em: <http://painel.mec.gov.br/>. Acesso em: 15 mar. 2014.

Ministério da Educação. Portaria Normativa no 39, de 12 de dezembro de 2007. Institui o Programa Nacional de Assistência Estudantil - PNAES. Brasília, 2007. Disponível em: <http://portal.mec.gov.br/arquivos/pdf/portaria_pnaes.pdf>. Acesso em: 20 ago. 2014.

CÂMARA DOS DEPUTADOS. Decreto Presidencial nº 69.927, de 13 de janeiro de 1972. Institui em caráter nacional, o Programa "Bolsa de Trabalho". Disponível em: <http://www2.camara.leg.br/legin/fed/decret/1970-1979/decreto-69927-13-janeiro-1972418292-publicacaooriginal-1-pe.html>. Acesso em: 15 mar. 2014.

CANGUSSU, Ricardo Corrêa; SALVATO, Márcio Antônio; NAKABASHI, Luciano. Uma análise do capital humano sobre o nível de renda dos estados brasileiros: MRW versus Mincer. Estudos Econômicos, São Paulo, v. 40, n. 1, p. 153-183, 2010.

CASTRO, Biancca Scarpeline; SOUZA, Gustavo Costa de. O papel dos Núcleos de Inovação Tecnológica (NITs) nas universidades brasileiras. Liinc em Revista, Rio de Janeiro, v. 8, n. 1, mar. p 125-140, 2012.

CAVALCANTI, Marcos; GOMES, Elisabeth; PEREIRA, André. Gestão de empresas na sociedade do conhecimento: um roteiro para ação. Rio de Janeiro: Campus, 2001.

CHIARINI, Tulio; VIEIRA, Karina Pereira. Universidades como produtoras de conhecimento para o desenvolvimento econômico: sistema superior de ensino e as políticas de CT\&I. Revista Brasileira de Economia, v. 66, n. 1, p. 117-132, 2012.

CISLAGHI, Juliana Fiúza; SILVA, Matheus Thomaz da. Plano Nacional de Assistência Estudantil e a expansão de vagas nas universidades federais: abrindo o debate. V Encontro brasileiro de educação e marxismo. Marxismo, educação e emancipação humana. Florianópolis, SC, 2011. 
CONTINI, Elisio; SÉCHET, Patrick. Ainda há um longo caminho para a ciência e tecnologia no Brasil. Revista Brasileira de Pós-Graduação, v. 2, n. 3, 2011.

COSTA, Fabiana de Souza. O programa Universidade para Todos (PROUNI) no contexto Políticas de Educação, Trabalho e Juventude do Brasil. 2013.

CUNHA, Jacqueline Veneroso Alves da. Doutores em ciências contábeis da FEA-USP: análise sob a óptica da teoria do capital humano. 2007. Tese (Doutorado) - Faculdade de Economia e Contabilidade, Universidade de São Paulo, São Paulo, 2007.

DAVENPORT, Thomas H.; PRUSAK, Laurence. Conhecimento empresarial: como as organizações gerenciam o seu capital intelectual. 14. ed. Rio de Janeiro: Campus, 1999.

DENZIN, Norman K.; LINCOLN, Yvonna S. (Eds.). Handbook of qualitative research. 2. ed. Thousand Oaks, Califórnia: Sage Publications, 2000.

DESCY, Pascaline; TESSARING, Manfred. Apprendre: une valeur sûre. Évaluation et impact de l'éducation et de la formation. Troisième rapport sur la recherche en formation et enseignement professionnels en Europe: rapport de synthèse, 2006.

DUTTA, S.; BENAVENTE, D. Measuring innovation potential and results: the best performing economies. In: The global nnovation index 2011. Accelerating growth and development. Fontainebleau: France: INSEAD, 2011.

ESTRADA, Adrian Alvarez; RADAELLI, Andressa Benvenutti. Permanência na educação superior: aspectos da Assistência Estudantil. Cuadernos de Educación y Desarrollo, n. 44, 2014.

FÁVERO, M. L. A UNE em tempos de autoritarismo. Rio de Janeiro: Ed. UFRJ, 1995.

FERRARI, Alfonso Trujillo. Metodologia da ciência. 2. ed. Rio de Janeiro: Kennedy, 1974.

FLICK, Uwe. Uma introdução à pesquisa qualitativa. Porto Alegre: Bookman, 2004.

FÓRUM NACIONAL DE PRÓ-REITORES DE ASSUNTOS COMUNITÁRIOS E ESTUDANTIS - FONAPRACE. Perfil Socioeconômico e Cultural dos Estudantes de Graduação das Instituições Federais de Ensino Superior: Relatório Final da Pesquisa. Fórum Nacional de Pró-Reitores de Assuntos Comunitários e Estudantis. 1. ed. Brasília: FONAPRACE, 2004. 
Perfil Socioeconômico e Cultural dos Estudantes de Graduação das

Universidades Federais Brasileiras. Fórum Nacional de Pró-Reitores de Assuntos Comunitários e Estudantis (FONAPRACE). Brasília: FONAPRACE, 2011.

HERINGER, Rosana; FERREIRA, Renato. Análise das principais políticas de inclusão de estudantes negros no ensino superior no Brasil no período 2001-2008. Caminhos convergentes: Estado e sociedade na superação das desigualdades raciais no Brasil. Rio de Janeiro: Fundação Heinrich Boll, ActionAid, 2009.

ÍNDICE DE DESENVOLVIMENTO HUMANO MUNICIPAL BRASILEIRO - IDHM. Brasília: PNUD, IPEA, FJP, 2013.

INSTITUTO BRASILEIRO DE GEOGRAFIA E ESTATÍSTICA - IBGE. PINTEC Pesquisa de Inovação 2011. Rio de Janeiro: IBGE, 2013.

INSTITUTO DE PESQUISA ECONÔMICA APLICADA - IPEA. Gastos com a Política Social: alavanca para o crescimento com distribuição de renda. Brasília: IPEA, 2011. (Comunicado do IPEA $n^{\circ}$ 75)

INSTITUTO NACIONAL DE ESTUDOS E PESQUISAS EDUCACIONAIS ANÍSIO TEIXEIRA - INEP. Censo da educação superior: 2011 - resumo técnico. Brasília: Instituto Nacional de Estudos e Pesquisas Educacionais Anísio Teixeira, 2013.

MARCONI, Marina de Andrade; LAKATOS, Eva Maria. Fundamentos de metodologia científica. 5. ed. São Paulo: Atlas, 2003.

LANGONI, C. Distribuição de renda e desenvolvimento econômico do Brasil. Rio de Janeiro: Expressão e Cultura, 1973.

MACIEL, Pedro Jucá. Finanças públicas no Brasil: uma abordagem orientada para políticas públicas. RAP - Revista Brasileira de Administração Pública, v. 47, n. 5, 2013.

MARTINS, Vera Lúcia. A importância do capital humano como diferencial competitivo para o sucesso das empresas: um estudo dos artigos publicados no período de 2000 a 2008 na revista RAE. Revista Eletrônica de Ciências Empresariais, a. 3, n. 5, ago./dez. 2009.

MINCER, J. Human capital and economic growth. NBER Working Paper Series, n. 803, p. 30, 1981. 
NEVES, Clarissa Eckert Baeta; NEVES, Fabrício Monteiro. Pesquisa e inovação: novos desafios para a educação superior no Brasil e na Alemanha. Caderno CRH, v. 24, n. 63, p. 481-501, 2011.

NUNES, Edson. Desafio estratégico da política pública: o Ensino Superior brasileiro. RAP, Rio de Janeiro, ed. esp. comemorativa, p. 103-47, 1967-2007.

ORGANIZAÇÃO PARA A COOPERAÇÃO E DESENVOLVIMENTO ECONÔMICO OECD. Education at a Glance 2013: OECD Indicators, OECD Publishing. 2013. Disponível em: <http://www.oecd-ilibrary.org/education/education-at-a-glance-2013_eag-2013-en>. Acesso em: 15 mar. 2014.

PISA 2012 Assessment and Analytical Framework: Mathematics, Reading, Science, Problem Solving and Financial Literacy, OECD Publishing. 2013. Disponível em: $<$ http://www.oecd-ilibrary.org/education/pisa-2012-assessment-and-analyticalframework_9789264190511-en>. Acesso em: 15 mar. 2014.

OLIVEIRA, Silvio Luiz de. Tratado de metodologia científica. São Paulo: Pioneira. 1997.

ROMERO, Carlos Cortrez. Lei da Inovação Tecnológica: críticas e contribuições. 2009. Disponível em: <http://www.senac.br/BTS/282/boltec282d.htm>. Acesso em: 28 ago. 2014.

SACHSIDA, Adolfo; LOUREIRO, Paulo Roberto Amorim; MENDONÇA, Mário Jorge Cardoso de. Um estudo sobre retorno em escolaridade no Brasil. Revista Brasileira de Economia, v. 58, n. 2, p. 249-265, 2004.

SAMPAIO, Helena. Evolução do ensino superior brasileiro: 1808-1990. Documento de Trabalho NUPES, v. 8, p. 91, 1991.

SANTOS, Adilson Pereira dos; CERQUEIRA, Eustaquio Amazonas de. Ensino Superior: trajetória histórica e políticas recentes. 2011.

SCHULTZ, T. Capital humano. Rio de Janeiro: Zahar, 1973.

SCHWARTZMAN, Simon. Pesquisa Universitária e Inovação no Brasil: avaliação de políticas. 2008.

SOARES, S. S. D. Distribuição de renda no Brasil de 1976 a 2004 com ênfase no período entre 2001 e 2004. Brasília: IPEA, 2006. (Texto para Discussão nº 1166) 
SOARES, Fábio Veras; SOARES, Sergei; MEDEIROS, Marcelo; OSÓRIO, Rafael Guerreiro. Programas de transferência de renda no Brasil: impactos sobre a desigualdade. Brasília: IPEA, 2006. (Texto para Discussão n 1228)

TEIXEIRA, Wladimir Machado; MENEZES-FILHO, Naércio Aquino. Estimando o retorno à educação do Brasil considerando a legislação educacional brasileira como um instrumento. Revista de Economia Política, v. 32, n. 3, p. 479-496, 2012.

UNIVERSIDADE DE BRASÍLIA - UnB. Secretaria de Administração Acadêmica - SAA. Brasília, 2014a.

Diretoria de Desenvolvimento Social - DDS. Decanato de Assuntos Comunitários DAC. Brasília, 2014b.

UNIVERSIDADE ESTADUAL DE CAMPINAS - UNICAMP. Folha destaca Unicamp como líder de patentes entre universidades brasileira. 06 de março de 2012. Disponível em: <http://www.unicamp.br/unicamp/noticias/folha-destaca-unicamp-como-1\%C3\%ADder-depatentes-entre-universidades-brasileiras>. Acesso em: 09 maio. 2014.

VASCONCELOS, Natalia Batista. Programa Nacional de Assistência Estudantil: uma análise da evolução da Assistência Estudantil ao longo da história da educação superior no Brasil. Ensino em Re-Vista, 2010.

VELOSO, Fernando. A Evolução recente e propostas para a melhoria da Educação no Brasil. In: BACHA, Edmar Lisboa; SCHAWARTZMAN, Simon; MEDICI, André Cézar et al. Brasil: a nova agenda social. Rio de Janeiro: LTC, 2011.

VERGARA, Sylvia Constant. Projetos e relatórios de pesquisa em administração. São Paulo: Atlas, 2000.

WEISBROD, Burton A. Educação e investimento em capital humano. The Journal of Political Economy, v. 70, n. 5, p. 106-123, 1962.

YIN, Robert K. Case Study Research - Design and Methods. USA: Sage Publications Inc., 1989. 
ANEXOS 


\section{ANEXO A - DADOS DA SAA/UnB}

Os dados expressos a seguir, disponibilizados pela Secretaria de Administração Acadêmica (SAA) da Universidade de Brasília tratam dos trancamentos e desligamentos estudantis - período 2000/1-2014/1.

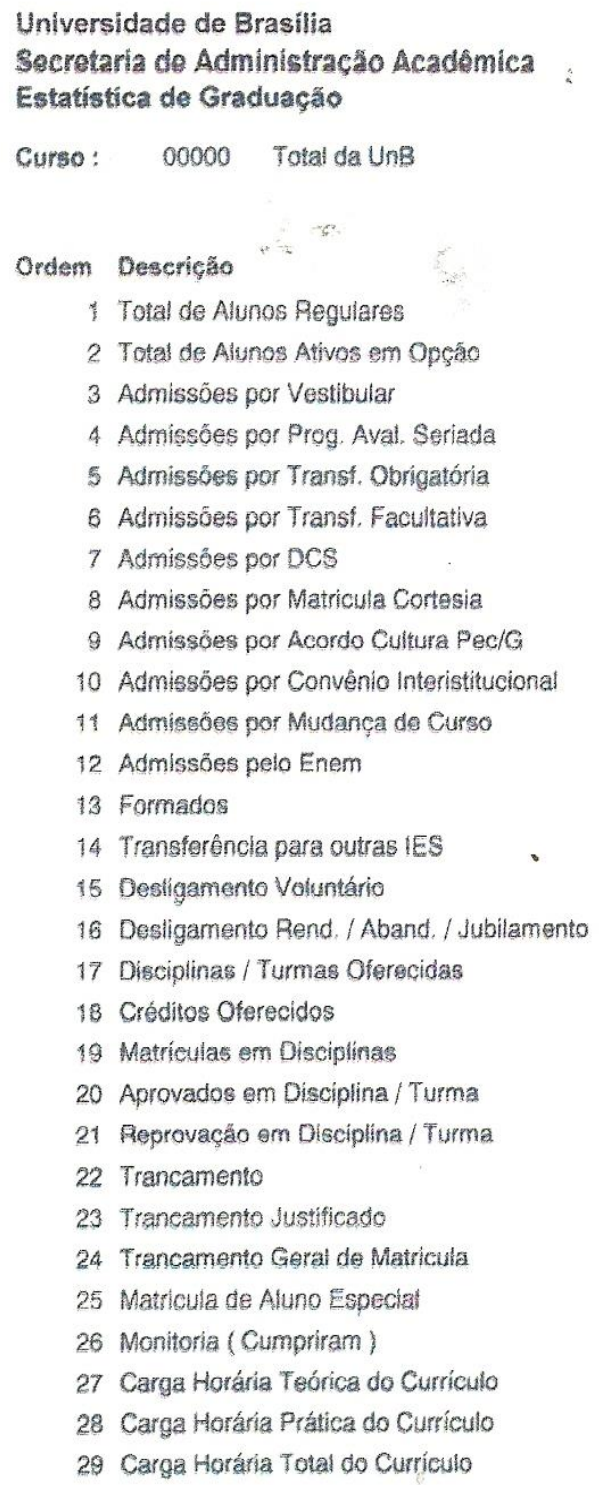

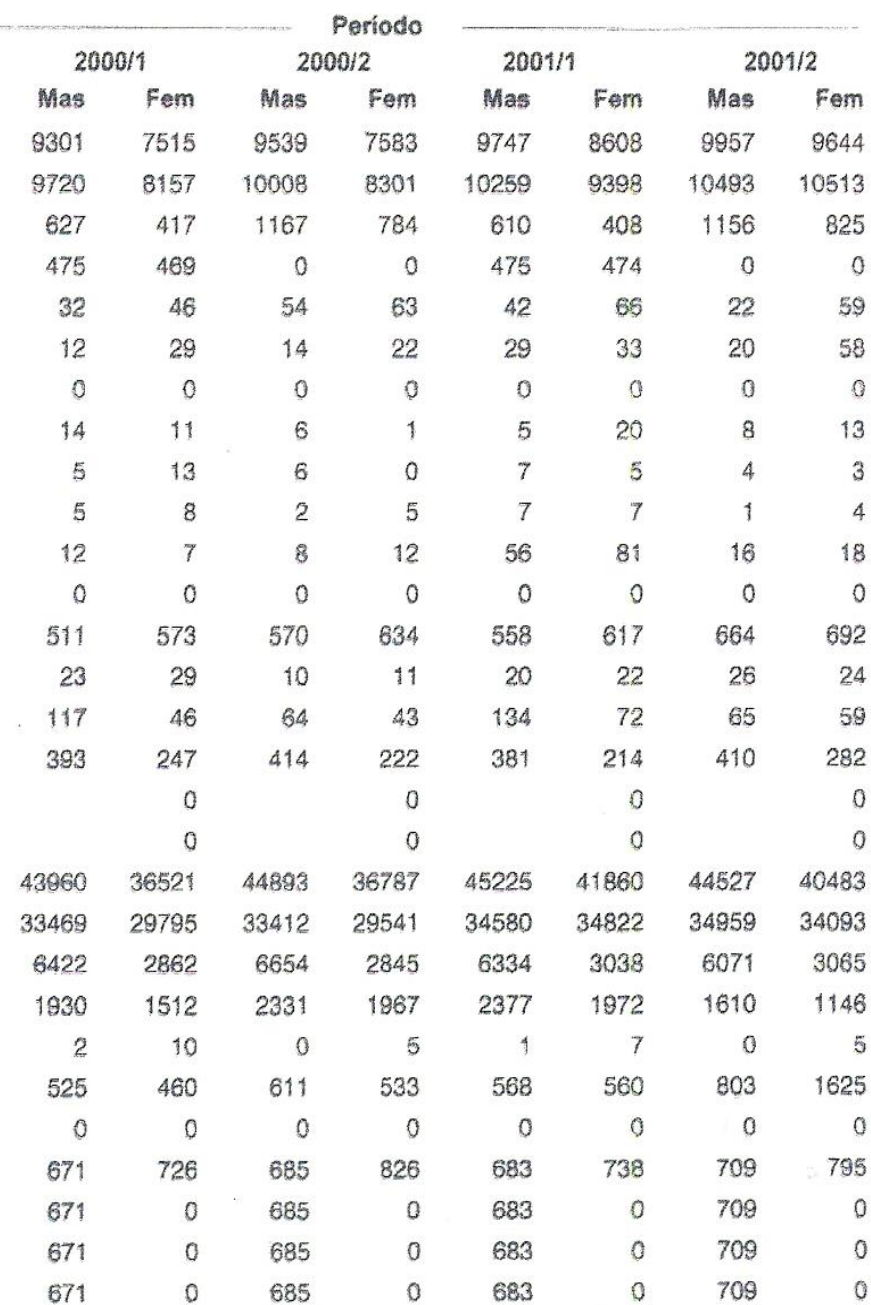


Universidade de Brasilla

Página:

1 de 1

Secrotaria de Administraça Acadêmica

Emissão: $\quad 26 / 11 / 201 \quad 08: 35$

Estatistica de Graduação

Curso: $\quad 00000$ Total da UnB

\begin{tabular}{|c|c|}
\hline Ordem & Descriçẫo \\
\hline 1 & Total de Alunos Regulares \\
\hline 2 & Total de Alunos Ativos em Opcăo \\
\hline 3 & Admissóes por Vestibular \\
\hline 4 & Admissöes por Prog. Aval. Seriada \\
\hline 5 & Admissóes por Transf. Obrigatória \\
\hline 6 & Admissões por Transf. Facultativa \\
\hline 7 & Admissöes por DCS \\
\hline 8 & Admissóes por Matricula Contesia \\
\hline 9 & Admissóes por Acordo Cultura Pec/G \\
\hline 10 & Admissóes por Convênio Interistitucional \\
\hline 11 & Admissöes por Mudança de Curso \\
\hline 12 & Admissôes pelo Enem \\
\hline 13 & Formados \\
\hline 14 & Transferéncia para outras IES \\
\hline 15 & Desligamento Voluntârio \\
\hline 16 & Desligamento Rend. / Aband. / Jubilamento \\
\hline 17 & Disciplinas / Turmas Oferecidas \\
\hline 18 & Créditos Oferecidos \\
\hline 19 & Matriculas em Disciplinas \\
\hline 20 & Aprovados em Disciplina / Turma \\
\hline 21 & Reprovaçắo em Disciplina / Turma \\
\hline 22 & Trancamento \\
\hline 23 & Trancamento Justificado \\
\hline 24 & Trancamento Geral de Matricula \\
\hline 25 & Matricula de Aluno Especial \\
\hline 26 & Monitoria (Cumpriram) \\
\hline 27 & Carga Horária Teórica do Currículo \\
\hline 28 & Carga Horária Prática do Curriculo \\
\hline 29 & Carga Horária Total do Currículo \\
\hline
\end{tabular}

\begin{tabular}{|c|c|c|c|c|c|c|c|}
\hline \multicolumn{2}{|c|}{$2002 / 1$} & \multicolumn{2}{|c|}{$\begin{array}{l}\text { Período } \\
2002 / 2\end{array}$} & \multicolumn{2}{|c|}{$2003 / 1$} & \multicolumn{2}{|c|}{$2003 / 2$} \\
\hline Mas & Fem & Mas & Fem & Mas & Fem & Mas & Fem \\
\hline 10044 & 9934 & 10122 & 9960 & 10267 & 10121 & 10434 & 10167 \\
\hline 10874 & 10832 & 10807 & 11046 & 10987 & 11309 & 11108 & 11263 \\
\hline 573 & 461 & 1153 & 829 & 601 & 424 & 1237 & 754 \\
\hline 461 & 498 & 0 & 0 & 579 & 567 & 0 & 0 \\
\hline 45 & 63 & 39 & 22 & 42 & 53 & 47 & 42 \\
\hline 25 & 45 & 24 & 45 & 28 & 43 & 7 & 16 \\
\hline 0 & 0 & 0 & 0 & 0 & 0 & 0 & 0 \\
\hline 8 & 18 & 10 & 14 & 12 & 20 & 15 & 15 \\
\hline 6 & 7 & 6 & 3 & 2 & 8 & 3 & 0 \\
\hline 3 & 10 & 3 & 3 & 4 & 11 & 0 & 8 \\
\hline 8 & 7 & 12 & 14 & 11 & 12 & 13 & 9 \\
\hline 0 & 0 & 0 & 0 & 0 & 0 & 0 & 0 \\
\hline 609 & 628 & 691 & 683 & 723 & 765 & 876 & 1589 \\
\hline 16 & 17 & 12 & 10 & 15 & 16 & 18 & 13 \\
\hline 153 & 73 & 51 & 37 & 180 & 66 & 58 & 37 \\
\hline \multirow[t]{3}{*}{412} & 259 & 431 & 316 & 393 & 262 & 354 & 278 \\
\hline & 0 & & 0 & & 0 & & 0 \\
\hline & 0 & & 0 & & 0 & & 0 \\
\hline 47530 & 49798 & 48311 & 47905 & 49455 & 49930 & 49202 & 48915 \\
\hline 38105 & 43241 & 38266 & 41751 & 39794 & 43591 & 38928 & 43021 \\
\hline 5982 & 2893 & 6184 & 3021 & 6172 & 2997 & 6568 & 3046 \\
\hline 1803 & 1465 & 2008 & 1514 & 1615 & 1336 & 1879 & 1358 \\
\hline 3 & 13 & 2 & 4 & 7 & 10 & 2 & 6 \\
\hline 610 & 653 & 599 & 646 & 587 & 619 & 510 & 567 \\
\hline 0 & 0 & 0 & 0 & 0 & 0 & 0 & 0 \\
\hline 716 & 916 & 796 & 956 & 811 & 988 & 811 & 960 \\
\hline 716 & 0 & 796 & 0 & 811 & 0 & 811 & 0 \\
\hline 716 & 0 & 796 & 0 & 811 & 0 & 811 & 0 \\
\hline 716 & 0 & 796 & 0 & 811 & 0 & 811 & 0 \\
\hline
\end{tabular}


Universidade de Brasilia

Pagina:

1 de 1

Secretaria de Administraçäo Acadêmica

Emissăo: 26/11/201 08:36

Estatistica de Graduaçăo

Curso: $\quad 00000$ Total da UnB

\begin{tabular}{|c|c|}
\hline Ordem & Descriçâo \\
\hline 1 & Total de Alunos Regulares \\
\hline 2 & Total de Alunos Ativos em Opç̧ăo \\
\hline 3 & Admissbes por Vestibular \\
\hline 4 & Admissóes por Prog. Aval. Seriada \\
\hline 5 & Admissóes por Transf. Obrigatória \\
\hline 6 & Admissobes por Transt. Facultativa \\
\hline 7 & Admissóes por DCS \\
\hline 8 & Admissdes por Matricula Cortesia \\
\hline 9 & Admissdes por Acordo Culturs Pec/G \\
\hline 10 , & Admissdes por Convếnio Interistitucional \\
\hline 11 & Admissóes por Mudança de Curso \\
\hline 12 , & Admissöes pelo Enem \\
\hline 13 & Formados \\
\hline 14 & Transferència para outras IES \\
\hline 15 & Desligamento Voluntário \\
\hline 16 & Destigamento Rend. / Aband. / Jubilamento \\
\hline 17 & Disciplinas / Turmas Oferecidas \\
\hline 18 & Créditos Oforecidos \\
\hline 19 ! & Matriculas em Disciplinas \\
\hline 20 & Aprovados em Disciplina / Turma \\
\hline 21 & Reprovaçáo em Disciplina / Turma \\
\hline 22 & Trancamento \\
\hline 23 & Trancamento Justificado \\
\hline 247 & Trancamento Geral de Matricula \\
\hline 251 & Matricula de Aluno Especial \\
\hline 261 & Monitoria (Cumpriram ) \\
\hline 27 & Carga Horária Teórica do Curriculo \\
\hline 28 & Carga Horária Prática do Curriculo \\
\hline 29 & Carga Horária Total do Curriculo \\
\hline
\end{tabular}

\begin{tabular}{|c|c|c|c|c|c|c|c|}
\hline \multicolumn{2}{|c|}{$2004 / 1$} & \multicolumn{2}{|c|}{$\begin{array}{l}\text { Periodo } \\
2004 / 2\end{array}$} & \multicolumn{2}{|c|}{$2005 / 1$} & \multicolumn{2}{|c|}{$2005 / 2$} \\
\hline Mas & Fem & Mas & Fem & Mas & Fem & Mas & Fem \\
\hline 10394 & 9546 & 10577 & 9543 & 10322 & 8672 & 10328 & 8535 \\
\hline 11055 & 10578 & 11265 & 10523 & 11046 & 9697 & 11111 & 9636 \\
\hline 601 & 406 & 1200 & 779 & 564 & 451 & 1196 & 818 \\
\hline 443 & 523 & 0 & 0 & 443 & 535 & 0 & 0 \\
\hline 62 & 69 & 94 & 75 & 61 & 47 & 36 & 34 \\
\hline 20 & 43 & 20 & 21 & 19 & 19 & 41 & 30 \\
\hline 0 & 0 & 0 & 0 & 0 & 0 & 0 & 0 \\
\hline 13 & 9 & 22 & 13 & 10 & 8 & 14 & 4 \\
\hline 8 & 9 & 2 & 1 & 10 & 6 & 7 & 4 \\
\hline 2 & 4 & 1 & 8 & 2 & 11 & 1 & 8 \\
\hline 9 & 9 & 24 & 13 & 16 & 7 & 14 & 17 \\
\hline 0 & 0 & 0 & 0 & 0 & 0 & 0 & 0 \\
\hline 734 & 797 & 884 & 1713 & 695 & 764 & 801 & 913 \\
\hline 3 & 1 & 21 & 17 & 16 & 16 & 24 & 20 \\
\hline 152 & 66 & 73 & 31 & 181 & 58 & 122 & 65 \\
\hline \multirow[t]{3}{*}{374} & 286 & 494 & 340 & 418 & 303 & 468 & 299 \\
\hline & 0 & & 0 & & 0 & & 0 \\
\hline & 0 & & 0 & & 0 & & 0 \\
\hline 49789 & 47158 & 50620 & 46080 & 48612 & 41451 & 46835 & 37801 \\
\hline 39703 & 40729 & 39864 & 40091 & 38826 & 34914 & 36748 & 32038 \\
\hline 6591 & 2994 & 6723 & 3130 & 6349 & 2945 & 6722 & 3131 \\
\hline 1686 & 1367 & 1404 & 1084 & 2171 & 1814 & 1644 & 1453 \\
\hline 5 & 13 & 7 & 6 & 107 & 39 & 216 & 124 \\
\hline 554 & 552 & 582 & 546 & 554 & 574 & 678 & 676 \\
\hline 0 & 0 & 0 & 0 & 0 & 0 & 0 & 0 \\
\hline 884 & 975 & 824 & 960 & 762 & 881 & 784 & 880 \\
\hline 884 & 0 & 824 & 0 & 762 & 0 & 784 & 0 \\
\hline 884 & 0 & 824 & 0 & 762 & 0 & 784 & 0 \\
\hline 884 & 0 & 824 & 0 & 762 & 0 & 784 & 0 \\
\hline
\end{tabular}


Universidade de Brasilia

Página:

1 de 1

Secrotaria de Administraçăo Acadômica

Emissăo: $\quad$ 26/11/201 08:36

Estatistica de Graduação

Curso: 00000 Total da UnB

\begin{tabular}{|c|c|}
\hline rdem & Descriçăo \\
\hline 1 & Total de Alunos Regulares \\
\hline 2 & Total de Alunos Atives em Opção \\
\hline 3 & Admissöes por Vestibular \\
\hline 4 & Admissôes por Prog. Aval. Seriada \\
\hline 5 & Admissôes por Transf. Obrigatória \\
\hline 6 & Admissbes por Transt. Facultativa \\
\hline 7 & Admissões por DCS \\
\hline 8 & Admissbes por Matricula Cortesia \\
\hline 9 & Admissóes por Acordo Cultura Pec/G \\
\hline 10 & Admissóes por Convênio Interistitucional \\
\hline 11 & Admissōes por Mudança de Curso \\
\hline 12 & Admissôes pelo Enem \\
\hline 13 & Formados \\
\hline 14 & Transferência para outras IES \\
\hline 15 & Dessligamento Voluntário \\
\hline 16 & Desligamento Rend. / Aband. / Jubilamento \\
\hline 17 & Disciplinas / Turmas Oferecidas \\
\hline 18 & Créditos Oferecidos \\
\hline 191 & Matriculas em Disciplinas \\
\hline 20 & Aprovados em Disciplina / Turma \\
\hline 21 & Reprovaçảo em Disciplina / Turma \\
\hline 227 & Trancamento \\
\hline 237 & Trancamento Justificado \\
\hline 247 & Trancamento Geral de Matricula \\
\hline $25 \mathrm{~A}$ & Matricula de Aluno Especial \\
\hline $26 \mathrm{~N}$ & Monitoria (Cumpriram) \\
\hline $27 c$ & Carga Horária Teórica do Currículo \\
\hline $28 c$ & Carga Horária Prática do Currículo \\
\hline 290 & Carga Horária Tokal do Currículo \\
\hline
\end{tabular}

\begin{tabular}{|c|c|c|c|c|c|c|c|}
\hline \multicolumn{2}{|c|}{$2006 / 1$} & \multicolumn{2}{|c|}{$2006 / 2$} & \multicolumn{2}{|c|}{$2007 / 1$} & \multicolumn{2}{|c|}{$2007 / 2$} \\
\hline Mas & Fem & Mas & Fem & Mas & Fem & Mas & Fem \\
\hline 10336 & 8630 & 10792 & 9002 & 10779 & 9863 & 11331 & 10684 \\
\hline 11104 & 9690 & 11520 & 10008 & 11413 & 10795 & 11934 & 11547 \\
\hline 671 & 441 & 1563 & 1296 & 858 & 1214 & 1886 & 1788 \\
\hline 468 & 514 & 0 & 0 & 436 & 555 & 0 & 0 \\
\hline 76 & 56 & 36 & 20 & 40 & 59 & 45 & 30 \\
\hline 26 & 32 & 25 & 25 & 33 & 27 & 33 & 29 \\
\hline 0 & 0 & 0 & 0 & 0 & 0 & 0 & 0 \\
\hline 15 & 17 & $\theta$ & 6 & 13 & 14 & 8 & 9 \\
\hline 5 & 7 & 1 & 4 & 5 & 8 & 1 & 2 \\
\hline 2 & 3 & 10 & 7 & 6 & 5 & 6 & 5 \\
\hline 26 & 21 & 16 & 11 & 12 & 12 & 18 & 16 \\
\hline 0 & 0 & 0 & 0 & 0 & 0 & 0 & 0 \\
\hline 710 & 759 & 920 & 909 & 831 & 837 & 833 & 885 \\
\hline 22 & 18 & 19 & 17 & 13 & 10 & 4 & 3 \\
\hline 150 & 87 & 102 & 55 & 143 & 69 & 102 & 51 \\
\hline \multirow[t]{3}{*}{424} & 282 & 539 & 311 & 503 & 308 & 430 & 297 \\
\hline & 0 & & 0 & & 0 & & c \\
\hline & 0 & & 0 & & 0 & & $c$ \\
\hline 52354 & 43224 & 52553 & 43186 & 50950 & 44070 & 52550 & 46755 \\
\hline 41616 & 36934 & 41535 & 37023 & 40535 & 37588 & 41893 & 40351 \\
\hline 7985 & 3757 & 8414 & 3987 & 8055 & 3883 & 8903 & 4896 \\
\hline 1026 & 1060 & 1269 & 1165 & 1062 & 994 & 458 & 296 \\
\hline 135 & 68 & 185 & 137 & 136 & 74 & 169 & 106 \\
\hline 441 & 434 & 450 & 445 & 471 & 414 & 501 & 501 \\
\hline 0 & 0 & 0 & 0 & 0 & 0 & 0 & c \\
\hline 793 & 904 & 776 & 919 & 780 & 802 & 766 & 827 \\
\hline 793 & 0 & 776 & 0 & 780 & 0 & 766 & c \\
\hline 793 & 0 & 776 & 0 & 780 & 0 & 766 & c \\
\hline 793 & 0 & 776 & 0 & 780 & 0 & 766 & $c$ \\
\hline
\end{tabular}


Universidade de Brasilia

Página:

1 de 1

Secretaria de Administração Acadômica

Emissão: 26/11/201 08:37

\section{Estatistica de Graduação}

Curso: 00000 Total da UnB

\begin{tabular}{|c|c|}
\hline Ordem & Descriçăo \\
\hline 1 & Total de Alunos Regulares \\
\hline 2 & Total de Alunos Ativos em Opção \\
\hline 3 & Admissóes por Vestibular \\
\hline 4 & Admissões por Prog. Aval. Seriada \\
\hline 5 & Admissöes por Transf. Obrigatória \\
\hline 6 & Admissóes por Transf. Facultativa \\
\hline 7 & Admissöes por DCS \\
\hline 8 & Admissöes por Matricula Cortesia \\
\hline 9 & Admissóes por Acordo Cultura Pec/G \\
\hline 10 & Admissóes por Convênio Interistitucional \\
\hline 11 & Admissóes por Mudança de Curso \\
\hline 12 & Admissôes pelo Enem \\
\hline 13 & Formados \\
\hline $14^{\prime}$ & Transferência para outras IES \\
\hline 15 & Desligamento Voluntário \\
\hline 16 & Desligamento Rend. / Aband. / Jubilamento \\
\hline 17 & Disciplinas / Turmas Oferecidas \\
\hline 18 & Créditos Oferecidos \\
\hline 19 & Matriculas sm Disciplinas \\
\hline 20 & Aprovados em Disciplina / Turma \\
\hline 21 & Reprovaçāo em Disciplina / Turma \\
\hline 22 & Trancamento \\
\hline 23 & Trancamento Justificado \\
\hline 24 & Trancamento Geral de Matricula \\
\hline 25 & Matricula de Aluno Especial \\
\hline 26 & Monitoria (Cumpriram) \\
\hline 27 & Carga Horária Térica do Currículo \\
\hline 28 & Carga Horária Prática do Curriculo \\
\hline 29 & Carga Horária Total do Curriculo \\
\hline
\end{tabular}

\begin{tabular}{|c|c|c|c|c|c|c|c|}
\hline \multicolumn{2}{|c|}{$2008 / 1$} & \multicolumn{2}{|c|}{$2008 / 2$} & \multicolumn{2}{|c|}{$2009 / 1$} & \multicolumn{2}{|c|}{$2009 / 2$} \\
\hline Mas & Fem & Mas & Fem & Mas & Fem & Mas & Fem \\
\hline 11490 & 11517 & 11796 & 12018 & 12413 & 13203 & 12934 & 13857 \\
\hline 12073 & 12374 & 12402 & 12929 & 12934 & 13996 & 13429 & 14546 \\
\hline 923 & 1290 & 1615 & 1389 & 1258 & 1505 & 1829 & 1502 \\
\hline 475 & 548 & 0 & 0 & 643 & 707 & 0 & \\
\hline 42 & 38 & 29 & 32 & 59 & 63 & 19 & 24 \\
\hline 26 & 28 & 25 & 31 & 62 & 75 & 52 & 91 \\
\hline 0 & 0 & 0 & 0 & 0 & 0 & 0 & \\
\hline 13 & 8 & 8 & 7 & 18 & 11 & 9 & \\
\hline 10 & 9 & 4 & 5 & 12 & 9 & 6 & \\
\hline 17 & 8 & 3 & 9 & 3 & 6 & 12 & 12 \\
\hline 16 & 12 & 15 & 20 & 11 & 15 & 13 & 28 \\
\hline 0 & 0 & 0 & 0 & 0 & 0 & 0 & \\
\hline 804 & 762 & 894 & 1024 & 826 & 878 & 970 & 1601 \\
\hline 15 & 11 & 4 & 6 & 13 & 2 & 9 & . \\
\hline 211 & 108 & 73 & 70 & 36 & 42 & 35 & 42 \\
\hline \multirow[t]{3}{*}{401} & 237 & 498 & 325 & 428 & 257 & 415 & 381 \\
\hline & 0 & & 0 & & 0 & & \\
\hline & 0 & & 0 & & 0 & & \\
\hline 55169 & 50731 & 54809 & 51305 & 58012 & 57265 & 61410 & 61633 \\
\hline 43739 & 4.3456 & 43101 & 43543 & 44569 & 47057 & 45344 & 48901 \\
\hline 9250 & 5320 & 9855 & 5656 & 10459 & 7115 & 12079 & 8525 \\
\hline 599 & 541 & 507 & 402 & 427 & 456 & 1110 & 1212 \\
\hline 170 & 86 & 95 & 58 & 52. & 34 & 496 & 179 \\
\hline 517 & 510 & 503 & 578 & 567 & 578 & 543 & 552 \\
\hline 0 & 0 & 0 & 0 & 0 & 0 & 0 & 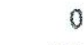 \\
\hline 733 & 926 & 824 & 954 & 871 & 976 & 898 & 982 \\
\hline 733 & 0 & 824 & 0 & 871 & 0 & 898 & \\
\hline 733 & 0 & 824 & 0 & 871 & 0 & 898 & \\
\hline 733 & 0 & 824 & 0 & 871 & 0 & 898 & \\
\hline
\end{tabular}


Universidade de Brasilia

Página:

1 de 1

Secretaria de Administração Académica

Emissăo: 26/11/201 08:38

Curso : 00000 Total da UnB

\begin{tabular}{|c|c|}
\hline Ordem & Descrição \\
\hline 1 & Total de Alunos Regulares \\
\hline 2 & Total de Alunos Ativos em Opçấo \\
\hline 3 & Admissóes por Vestibular \\
\hline 4 & Admissöes por Prog. Aval. Seriada \\
\hline 5 & Admissóes por Transf. Obrigatória \\
\hline 6 & Admissões por Transt. Facultativa \\
\hline 7 & Admissóes por DCS \\
\hline 8 & Admissőes por Matricula Cortesia \\
\hline 9 & Admissōes por Acordo Cultura $\mathrm{Pec} / \mathrm{G}$ \\
\hline 10 & Admisssōes por Convênio Interistitucional \\
\hline 11 & Admissöes por Mudança de Curso \\
\hline 12 & Admissöes pelo Enem \\
\hline 13 & Formados \\
\hline 14 & Transferéncia para outras IES \\
\hline 15 & Desligamento Voluntario \\
\hline 16 & Desligamento Rend. / Aband. / Jubilamento \\
\hline 17 & Disciplinas / Turmas Oferecidas \\
\hline 18 & Créditos Oferecidos \\
\hline 19 & Matriculas em Disciplinas \\
\hline 20 & Aprovados em Disciplina / Turma \\
\hline 21 & Reprovaçăo em Disciplina / Turma \\
\hline 22 & Trancamento \\
\hline 23 & Trancamento Justificado \\
\hline 24 & Trancamento Geral de Matricula \\
\hline 25 & Matricula de Aluno Especial \\
\hline 26 & Monitoria (Gumpriram) \\
\hline 27 & Carga Horária Teórica do Currículo \\
\hline 28 & Carga Horária Prática do Currículo \\
\hline 29 & Carga Horária Total do Currículo \\
\hline
\end{tabular}

\begin{tabular}{|c|c|c|c|c|c|c|c|}
\hline \multicolumn{8}{|c|}{ Periodo } \\
\hline \multicolumn{2}{|c|}{$2010 / 1$} & \multicolumn{2}{|c|}{$2010 / 2$} & \multicolumn{2}{|c|}{$2011 / 1$} & \multicolumn{2}{|c|}{$2011 / 2$} \\
\hline Mas & Fem & Mas & Fem & Mas & Fom & Mas & Fem \\
\hline 13217 & 13882 & 13973 & 14753 & 14508 & 15354 & 15075 & 15546 \\
\hline 13714 & 14562 & 14448 & 15417 & 14935 & 15959 & 15443 & 16057 \\
\hline 1058 & 1015 & 2106 & 2041 & 1649 & 1847 & 2090 & 1750 \\
\hline 715 & 887 & 1 & 0 & 682 & 709 & 1 & 0 \\
\hline 41 & 48 & 34 & 25 & 52 & 60 & 24 & 19 \\
\hline 34 & 76 & 54 & 69 & 59 & 79 & 55 & 54 \\
\hline 0 & 0 & 0 & 0 & 20 & 28 & 37 & 42 \\
\hline 8 & 15 & 9 & 5 & 7 & 5 & 6 & 6 \\
\hline 4 & 5 & 0 & 0 & 5 & 1 & 2 & 1 \\
\hline 14 & 16 & 9 & 11 & 12 & 15 & 12 & 34 \\
\hline 13 & 11 & 19 & 15 & 45 & 23 & 60 & 30 \\
\hline 0 & 0 & 0 & 0 & 41 & 56 & 43 & 66 \\
\hline 760 & 909 & 974 & 1492 & 890 & 1030 & 953 & 1098 \\
\hline 11 & 10 & 17 & 10 & 15 & 11 & 10 & 7 \\
\hline 55 & 51 & 64 & 58 & 70 & 60 & 53 & 42 \\
\hline \multirow[t]{3}{*}{536} & 324 & 749 & 694 & 499 & 724 & 683 & 493 \\
\hline & 0 & & 0 & & 0 & & 0 \\
\hline & 0 & & 0 & & 0 & & 0 \\
\hline 65782 & 66619 & 70050 & 70997 & 72498 & 77911 & 72477 & 76398 \\
\hline 49447 & 54199 & 51062 & 57188 & 54591 & 63126 & 53856 & 62557 \\
\hline 13135 & 8703 & 15261 & 10183 & 13924 & 9808 & 13843 & 9592 \\
\hline 1052 & 809 & 407 & 541 & 466 & 680 & 2450 & 2063 \\
\hline 68 & 43 & 108 & 96 & 67 & 53 & 476 & 372 \\
\hline 671 & 650 & 613 & 688 & 790 & 713 & 979 & 896 \\
\hline 0 & 0 & 0 & 0 & 0 & 0 & 0 & 0 \\
\hline 830 & 915 & 1047 & 1134 & 1049 & 1228 & 1184 & 1344 \\
\hline 830 & 0 & 1047 & 0 & 1049 & 0 & 1184 & 0 \\
\hline 830 & 0 & 1047 & 0 & 1049 & 0 & 1184 & 0 \\
\hline 830 & 0 & 1047 & 0 & 1049 & 0 & 1184 & 0 \\
\hline
\end{tabular}


Universidade de Brasilia

Secrotaria de Administraçấo Académica Estatística de Graduaçäo

Curso: 00000 Total da UnB

\section{Ordem Descrição}

1 Total de Alunos Aegulares

2 Total de Alunos Ativos em Opçăo

3 Admissöes por Vestibular

4 Adrnissöes por Prog. Aval. Seriada

5 Admissőes por Transf. Obrigatória

6 Admissõos por Transt. Facultativa

7 Admissōes por DCS

8 Admissóes por Matricula Cortesia

9 Admissones por Acordo Cultura Pec/G

10 Admissőes por Convênio interistitucional

11 Admissóes por Mudança de Curso

12 Admissóes pelo Enem

13 Formados

14 Transferência para outras IES .

15 Desligamento Voluntário

16 Desligamento Rend. / Aband. / Jubilamento

17 Disciplinas / Turmas Oferecidas

18 Créditos Oferecidos

19 Matriculas em Disciplinas

20 Aprovados em Disciplina / Turma

21 Reprovação em Disciplina / Turma

22 Trancamento

23 Trancamento Justificado

24. Trancamento Geral de Matricula

25 Matricula de Aluno Especial

26 Monitoria (Cumpriram)

27 Carga Horária Teórica do Currículo

28 Carga Horária Prática do Currículo

29 Carga Horária Total do Currículo
Página:

1 de 1

Emissăo: $\quad 26 / 11 / 201 \quad 08: 38$

\begin{tabular}{|c|c|c|c|c|c|c|c|}
\hline \multirow{2}{*}{\multicolumn{2}{|c|}{$2012 / 1$}} & \multirow{2}{*}{\multicolumn{2}{|c|}{$\begin{array}{l}\text { Período } \\
\text { 2012/2 }\end{array}$}} & \\
\hline & & & & \multicolumn{2}{|c|}{$2013 / 1$} & \multicolumn{2}{|c|}{$2013 / 2$} \\
\hline Mas & Fem & Mas & Fom & Mas & Fem & Mas & Fom \\
\hline 15354 & 16393 & 15560 & 16926 & 15808 & 17230 & 16347 & 17570 \\
\hline 15652 & 16771 & 15761 & 17185 & 15967 & 17431 & 16473 & 17710 \\
\hline 816 & 955 & 1488 & 1477 & 1060 & 1028 & 2079 & 1887 \\
\hline 833 & 981 & 1 & 0 & 664 & 751 & 0 & 0 \\
\hline 50 & 43 & 37 & 29 & 47 & 31 & 24 & 19 \\
\hline 49 & 62 & 28 & 30 & 23 & 32 & 23 & 31 \\
\hline 33 & 34 & 48 & 47 & 34 & 24 & 45 & 31 \\
\hline 13 & 4 & 8 & 2 & 2 & 8 & 2 & 6 \\
\hline 1 & 2 & 1 & 0 & 4 & 3 & 2 & 0 \\
\hline 31 & 25 & 19 & 16 & 23 & 29 & 26 & 32 \\
\hline 41 & 24 & 66 & 51 & 59 & 52 & 77 & 72 \\
\hline 166 & 267 & 376 & 503 & 235 & 260 & 43 & 51 \\
\hline 781 & 888 & 877 & 1263 & 720 & 1012 & 929 & 1087 \\
\hline 2 & 1 & 11 & 9 & 12 & 13 & 2 & 5 \\
\hline 83 & 64 & 75 & 63 & 66 & 59 & 69 & 54 \\
\hline \multirow[t]{3}{*}{767} & 551 & 786 & 550 & 707 & 631 & 774 & 627 \\
\hline & 0 & & 0 & & 0 & & 0 \\
\hline & 0 & & 0 & & 0 & & 0 \\
\hline 75517 & 83593 & 75379 & 84254 & 75021 & 85737 & 76371 & 84367 \\
\hline 55596 & 66952 & 55608 & 67981 & 55752 & 68622 & 55280 & 66546 \\
\hline 10677 & 8482 & 13799 & 10452 & 12263 & 9693 & 13808 & 10472 \\
\hline 4274 & 4126 & 3115 & 3408 & 4083 & 4310 & 4084 & 4258 \\
\hline 3406 & 2336 & 485 & 409 & 502 & 406 & 281 & 234 \\
\hline 1354 & 1177 & 1366 & 1299 & 1522 & 1219 & 1624 & 1479 \\
\hline 119 & 148 & 89 & 92 & 99 & 110 & 145 & 99 \\
\hline 1192 & 1521 & 1302 & 1574 & 1379 & 1737 & 1430 & 1800 \\
\hline 1192 & 0 & 1302 & 0 & 1379 & 0 & 1430 & 0 \\
\hline 1192 & 0 & 1302 & 0 & 1379 & 0 & 1430 & 0 \\
\hline 1192 & 0 & 1302 & 0 & 1379 & 0 & 1430 & 0 \\
\hline
\end{tabular}


Universidade de Brasília

Página:

1 de 1

Secretaria de Administração Acadêmica

Emissăo: 26/11/201 08:39 Estatistica de Graduação

Curso: $\quad 00000$ Total da UnB

\begin{tabular}{|c|c|}
\hline dem & Descrição \\
\hline 1 & Total de Alunos Regulares \\
\hline 2 & Total de Alunos Ativos em Opçắo \\
\hline 3 & Admissóes por Vestibular \\
\hline 4 & Admissóes por Prog. Aval. Seriada \\
\hline 5 & Admissóes por Transf. Obrigatória \\
\hline 6 & Admissöes por Transf. Facultativa \\
\hline 7 & Admissóes por DCS \\
\hline 8 & Admissöes por Matricula Cortesia \\
\hline 9 & Adrnissóes por Acordo Cultura Pec/G \\
\hline 10 & Admissỗes por Convênio Interistitucional \\
\hline 11 & Admissóes por Mudança de Curso \\
\hline 12 & Admissöes pelo Enem \\
\hline 13 & Formados \\
\hline 14 & Transferência para outras IES \\
\hline 15 & Desligamento Voluntário \\
\hline 16 & Desligamento Rend. / Aband. / Jubilamento \\
\hline 17 & Disciplinas / Turmas Oferecidas \\
\hline 18 & Créditos O'erecidos \\
\hline 19 & Matriculas em Disciplinas \\
\hline 20 & Aprovados em Disciplina / Turma \\
\hline 21 & Reprovação em Disciplina / Turma \\
\hline 22 & Trancamento \\
\hline 23 & Trancamento Justificado \\
\hline 24 & Trancamento Geral de Matricula \\
\hline 25 & Matricula de Aluno Especial \\
\hline 26 & Monitoria ( Cumpriram) \\
\hline 27 & Carga Horária Teórica do Currículo \\
\hline 28 & Carga Horária Prática do Currículo \\
\hline 29 & Carga Horária Total do Curriculo \\
\hline
\end{tabular}

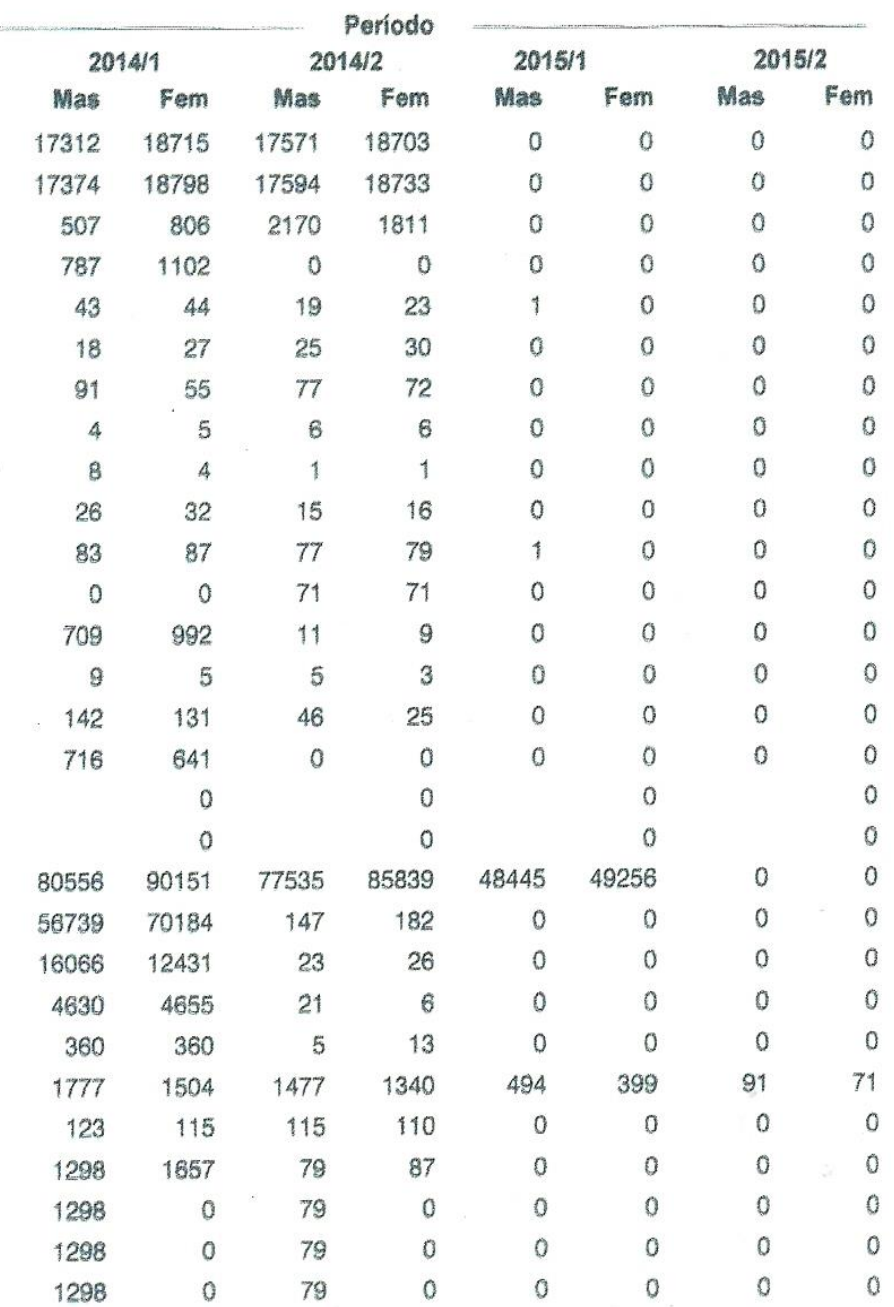




\section{ANEXO B - DADOS DA ASSISTÊNCIA ESTUDANTIL}

Os dados expressos a seguir, disponibilizados pela Diretoria de Desenvolvimento Social do Decanato de Assuntos Comunitários da Universidade de Brasília (DDS/DAC/UnB) tratam dos estudantes Participantes dos Programas de Assistências Estudantis (PPAES) até 05 de setembro de 2014.

1) Quanto ao resultado do estudo

\begin{tabular}{|c|c|c|}
\hline \multirow{2}{*}{ Resultado } & \multicolumn{2}{|c|}{ Estudantes } \\
\hline & Número & $\%$ \\
\hline PPAES & 3.058 & 93,4 \\
\hline NPPAES & 216 & 6,6 \\
\hline Total & 3.274 & 100 \\
\hline
\end{tabular}

2) Quanto ao sexo dos PPAES

\begin{tabular}{lcc} 
& \multirow{2}{c}{ Sexo } & Estudantes \\
\cline { 2 - 3 } & Número & $\%$ \\
\hline Feminino & 1.761 & 57,6 \\
Masculino & 1.297 & 42,4 \\
Total & 3.058 & 100 \\
\hline
\end{tabular}

3) Quanto à raça declarada dos PPAES

\begin{tabular}{|c|c|c|}
\hline \multirow{2}{*}{ Raça } & \multicolumn{2}{|c|}{ Estudantes } \\
\hline & Número & $\%$ \\
\hline Amarela & 91 & 3,0 \\
\hline Preta & 646 & 21,1 \\
\hline Parda & 1.493 & 48,8 \\
\hline Branca & 788 & 25,8 \\
\hline Indígena & 40 & 1,3 \\
\hline Total & 3.058 & 100 \\
\hline
\end{tabular}


4) Quanto ao ingresso por cotas dos PPAES

\begin{tabular}{|c|c|c|}
\hline \multirow{2}{*}{ Cota } & \multicolumn{2}{|c|}{ Estudantes } \\
\hline & Número & $\%$ \\
\hline Sim & 991 & 32,4 \\
\hline Não & 2067 & 67,6 \\
\hline Total & 3058 & 100 \\
\hline
\end{tabular}

5) Quanto ao tipo de cota dos PPAES

\begin{tabular}{lcc}
\hline \multirow{2}{*}{ Tipo de Cota } & \multicolumn{2}{c}{ Estudantes } \\
\cline { 2 - 3 } & Número & $\%$ \\
\hline Escola Pública Baixa Renda - PPI & 209 & 6,8 \\
Escola Pública Baixa Renda - Não & 115 & 3,8 \\
PPI & & \\
Escola Pública Alta Renda - PPI & 143 & 4,7 \\
Escola Pública Alta Renda - Não & 73 & 2,4 \\
PPI & 29 & 0,9 \\
Indígena & 422 & 13,8 \\
Negro & 2.067 & 67,6 \\
Universal & 3.058 & 100 \\
Total & & \\
\hline
\end{tabular}

6) Quanto aos campi dos PPAES

\begin{tabular}{|c|c|c|}
\hline \multirow{2}{*}{ Campus } & \multicolumn{2}{|c|}{ Estudantes } \\
\hline & Número & $\%$ \\
\hline Darcy Ribeiro & 1.886 & 61,7 \\
\hline FCE & 305 & 10,0 \\
\hline FGA & 247 & 8,1 \\
\hline FUP & 620 & 20,3 \\
\hline Total & 3.058 & 100 \\
\hline
\end{tabular}


7) Quanto ao curso dos PPAES (continua)

\begin{tabular}{|c|c|c|}
\hline \multirow{2}{*}{ Curso } & \multicolumn{2}{|c|}{ Estudantes } \\
\hline & Número & $\%$ \\
\hline Ciências Naturais & 221 & 7,23 \\
\hline Letras & 162 & 5,30 \\
\hline Educação do Campo & 147 & 4,81 \\
\hline Serviço Social & 132 & 4,32 \\
\hline Gestão do Agronegócio & 131 & 4,28 \\
\hline Gestão Ambiental & 120 & 3,92 \\
\hline Enfermagem & 107 & 3,50 \\
\hline Engenharia & 103 & 3,37 \\
\hline Pedagogia & 103 & 3,37 \\
\hline Agronomia & 96 & 3,14 \\
\hline Ciências Sociais & 89 & 2,91 \\
\hline Farmácia & 71 & 2,32 \\
\hline Saúde Coletiva & 65 & 2,13 \\
\hline Engenharia Florestal & 61 & 1,99 \\
\hline Fisioterapia & 61 & 1,99 \\
\hline Terapia Ocupacional & 59 & 1,93 \\
\hline Filosofia & 44 & 1,44 \\
\hline Biblioteconomia & 43 & 1,41 \\
\hline Ciências Contábeis & 42 & 1,37 \\
\hline Comunicação Social & 42 & 1,37 \\
\hline Engenharia de Energia & 41 & 1,34 \\
\hline Artes Cênicas & 40 & 1,31 \\
\hline Educação Física & 39 & 1,28 \\
\hline Engenharia Eletrônica & 39 & 1,28 \\
\hline Ciências Biológicas & 38 & 1,24 \\
\hline História & 38 & 1,24 \\
\hline Química & 38 & 1,24 \\
\hline Relações Internacionais & 34 & 1,11 \\
\hline Geografia & 33 & 1,08 \\
\hline Matemática & 31 & 1,01 \\
\hline Direito & 29 & 0,95 \\
\hline Engenharia de Software & 29 & 0,95 \\
\hline Geologia & 27 & 0,88 \\
\hline Psicologia & 27 & 0,88 \\
\hline Turismo & 27 & 0,88 \\
\hline Administração & 26 & 0,85 \\
\hline
\end{tabular}


7) Quanto ao curso dos PPAES (continuação)

\begin{tabular}{|c|c|c|}
\hline \multirow{2}{*}{ Curso } & \multicolumn{2}{|c|}{ Estudantes } \\
\hline & Número & $\%$ \\
\hline Ciência Política & 25 & 0,82 \\
\hline Física & 25 & 0,82 \\
\hline Engenharia Mecatrônica & 23 & 0,75 \\
\hline $\begin{array}{l}\text { Línguas Estrangeiras Aplicadas - } \\
\text { MSI }\end{array}$ & 20 & 0,65 \\
\hline Artes Plásticas & 19 & 0,62 \\
\hline Engenharia Civil & 19 & 0,62 \\
\hline Gestão de Políticas Públicas & 19 & 0,62 \\
\hline Medicina Veterinária & 19 & 0,62 \\
\hline Música & 19 & 0,62 \\
\hline Arquitetura e Urbanismo & 18 & 0,59 \\
\hline Engenharia Aeroespacial & 18 & 0,59 \\
\hline Estatística & 18 & 0,59 \\
\hline Letras-Tradução & 18 & 0,59 \\
\hline Ciências Ambientais & 17 & 0,56 \\
\hline Engenharia Automotiva & 17 & 0,56 \\
\hline Engenharia Elétrica & 17 & 0,56 \\
\hline Arquivologia & 16 & 0,52 \\
\hline Geofísica & 16 & 0,52 \\
\hline Computação & 15 & 0,49 \\
\hline Gestão em Saúde Coletiva & 15 & 0,49 \\
\hline Engenharia Ambiental & 14 & 0,46 \\
\hline Engenharia Mecânica & 13 & 0,43 \\
\hline Nutrição & 13 & 0,43 \\
\hline Odontologia & 13 & 0,43 \\
\hline Gestão de Agronegócios & 12 & 0,39 \\
\hline Biotecnologia & 11 & 0,36 \\
\hline Engenharia de Produção & 11 & 0,36 \\
\hline Letras-Tradução Espanhol & 11 & 0,36 \\
\hline Medicina & 11 & 0,36 \\
\hline Museologia & 11 & 0,36 \\
\hline Ciências Econômicas & 10 & 0,33 \\
\hline $\begin{array}{l}\text { Engenharia de Redes de } \\
\text { Comunicação }\end{array}$ & 10 & 0,33 \\
\hline Química Tecnológica & 10 & 0,33 \\
\hline Ciências Farmacêuticas & 9 & 0,29 \\
\hline
\end{tabular}


7) Quanto ao curso dos PPAES (continuação)

\begin{tabular}{|c|c|c|}
\hline \multirow{2}{*}{ Curso } & \multicolumn{2}{|c|}{ Estudantes } \\
\hline & Número & $\%$ \\
\hline Engenharia Química & 9 & 0,29 \\
\hline Fonoaudiologia & 8 & 0,26 \\
\hline Ciência da Computação & 7 & 0,23 \\
\hline Ciências Florestais & 7 & 0,23 \\
\hline Engenharia de Computação & 7 & 0,23 \\
\hline Teoria Crítica e História da Arte & 5 & 0,16 \\
\hline Botânica & 4 & 0,13 \\
\hline Design & 4 & 0,13 \\
\hline Educação Artística & 4 & 0,13 \\
\hline Ciência da Informação & 3 & 0,10 \\
\hline Sistemas Mecatrônicos & 3 & 0,10 \\
\hline Artes & 2 & 0,07 \\
\hline Ecologia & 2 & 0,07 \\
\hline Educação & 2 & 0,07 \\
\hline $\begin{array}{l}\text { Engenharia de Sistemas } \\
\text { Eletrônicos e de Automação }\end{array}$ & 2 & 0,07 \\
\hline Fitopatologia & 2 & 0,07 \\
\hline Geociências Aplicadas & 2 & 0,07 \\
\hline Linguística & 2 & 0,07 \\
\hline Linguística Aplicada & 2 & 0,07 \\
\hline Política Social & 2 & 0,07 \\
\hline Biologia Microbiana & 1 & 0,03 \\
\hline Ciências da Saúde & 1 & 0,03 \\
\hline Ciências e Tecnologias em Saúde & 1 & 0,03 \\
\hline Comunicação & 1 & 0,03 \\
\hline Desenvolvimento Sustentável & 1 & 0,03 \\
\hline Direitos Humanos e Cidadania & 1 & 0,03 \\
\hline Geotecnia & 1 & 0,03 \\
\hline Literatura & 1 & 0,03 \\
\hline $\begin{array}{l}\text { Meio Ambiente e } \\
\text { Desenvolvimento Rural }\end{array}$ & 1 & 0,03 \\
\hline $\begin{array}{l}\text { Psicologia Social do Trabalho e } \\
\text { das Organizações }\end{array}$ & 1 & 0,03 \\
\hline $\begin{array}{l}\text { Tecnologia Ambiental e Recursos } \\
\text { Hídricos }\end{array}$ & 1 & 0,03 \\
\hline
\end{tabular}


7) Quanto ao curso dos PPAES (conclusão)

\begin{tabular}{lccc} 
& \multirow{2}{*}{ Curso } & \multicolumn{2}{c}{ Estudantes } \\
\cline { 2 - 3 } & \multicolumn{2}{c}{ Número } & $\%$ \\
\hline Transportes & 1 & 0,03 \\
Total & 3.058 & 100 \\
\hline
\end{tabular}

